\title{
Mangifera indica (Mango): A Promising Medicinal Plant for Breast Cancer Therapy and Understanding Its Potential Mechanisms of Action
}

\author{
Kah Min Yap' \\ Mahendran Sekar (D) \\ Lay Jing Seow' \\ Siew Hua Gan $\mathbb{D D}^{2}$ \\ Srinivasa Reddy Bonam (D) ${ }^{3}$ \\ Nur Najihah Izzati Mat Rani ${ }^{4}$ \\ Pei Teng Lum' \\ Vetriselvan Subramaniyan ${ }^{5}$ \\ Yuan Seng $\mathrm{Wu}^{5}$ \\ Neeraj Kumar Fuloria ${ }^{6}$ \\ Shivkanya Fuloria ${ }^{6}$ \\ 'Department of Pharmaceutical \\ Chemistry, Faculty of Pharmacy and \\ Health Sciences, Universiti Kuala Lumpur \\ Royal College of Medicine Perak, Ipoh, \\ 30450, Perak, Malaysia; ${ }^{2}$ School of \\ Pharmacy, Monash University Malaysia, \\ Bandar Sunway, 47500, Selangor Darul \\ Ehsan, Malaysia; ${ }^{3}$ Institut National de la \\ Santé et de la Recherche Médicale; \\ Centre de Recherche des Cordeliers, \\ Equipe-Immunopathologie et \\ Immunointervention Thérapeutique, \\ Sorbonne Université, Université de Paris, \\ Paris, France; ${ }^{4}$ Faculty of Pharmacy and \\ Health Sciences, Universiti Kuala Lumpur \\ Royal College of Medicine Perak, Ipoh, \\ 30450, Perak, Malaysia; ${ }^{5}$ Faculty of \\ Medicine, Bioscience and Nursing, \\ MAHSA University, Selangor, 42610, \\ Malaysia; ${ }^{6}$ Faculty of Pharmacy, AIMST \\ University, Kedah, 08100, Malaysia
}

Correspondence: Mahendran Sekar

Tel +6016-3346653

Fax $+605-2536634$

Email mahendransekar@unikl.edu.my

\begin{abstract}
Globally, breast cancer is the most common cancer type and is one of the most significant causes of deaths in women. To date, multiple clinical interventions have been applied, including surgical resection, radiotherapy, endocrine therapy, targeted therapy and chemotherapy. However, 1) the lack of therapeutic options for metastatic breast cancer, 2) resistance to drug therapy and 3) the lack of more selective therapy for triple-negative breast cancer are some of the major challenges in tackling breast cancer. Given the safe nature of natural products, numerous studies have focused on their anti-cancer potentials. Mangifera indica, commonly known as mango, represents one of the most extensively investigated natural sources. In this review, we provide a comprehensive overview of $M$. indica extracts (bark, kernel, leaves, peel and pulp) and phytochemicals (mangiferin, norathyriol, gallotannins, gallic acid, pyrogallol, methyl gallate and quercetin) reported for in vitro and in vivo anti-breast cancer activities and their underlying mechanisms based on relevant literature from several scientific databases, including PubMed, Scopus and Google Scholar till date. Overall, the in vitro findings suggest that $M$. indica extracts and/or phytochemicals inhibit breast cancer cell growth, proliferation, migration and invasion as well as trigger apoptosis and cell cycle arrest. In vivo results demonstrated that there was a reduction in breast tumor xenograft growth. Several potential mechanisms underlying the anti-breast cancer activities have been reported, which include modulation of oxidative status, receptors, signalling pathways, miRNA expression, enzymes and cell cycle regulators. To further explore this medicinal plant against breast cancer, future research directions are addressed. The outcomes of the review revealed that $M$. indica extracts and their phytochemicals may have potential benefits in the management of breast cancer in women. However, to validate its utility in the creation of innovative and potent therapeutic agents to treat breast cancer, more dedicated research, especially clinical studies are needed to explore the anti-breast cancer potentials of M. indica extracts and their phytochemicals.
\end{abstract}

Keywords: mango, Mangifera indica, mangiferin, breast cancer, molecular mechanism, natural products, women's health

\section{Introduction}

Globally, breast cancer remains one of the most common cancers and causes of deaths in females. ${ }^{1}$ In 2020 alone, there were 2,261,419 new cases and 684,996 deaths globally. $^{2}$ In fact, most breast cancer cases are diagnosed at early stages when the disease is deemed as relatively curable. ${ }^{3}$ However, approximately $20-30 \%$ of these patients suffer from distant relapse with cancer cells spreading from the primary site to 
distant body parts (eg, bones, brain, distant nodal, liver, lungs and pleural/peritoneal metastases). ${ }^{3}$

The development of breast cancer is thought to be related to several important risk factors; with aging playing the major role, followed by family history (eg, BRCA1/2 mutations), reproductive factors (eg, early menarche and late menopause), hormonal imbalances (eg, elevated estrogen levels) and lifestyle (eg, high fat intake and alcohol consumption). ${ }^{4}$ In fact, only $5-10 \%$ of breast cancer cases are thought to have a genetic background, with $B R C A 1 / 2$ germline mutations contributing to approximately $50 \%$ of these hereditary cases. ${ }^{5,6}$

Breast cancer is a heterogenous disease owing to the existence of molecular and phenotypic variations within a patient's tumor (intra-tumoral heterogeneity) and between different patients' tumors (inter-tumoral heterogeneity). ${ }^{7}$ Based on immunohistochemistry and gene expression profiling, breast cancer can be classified into different biological subtypes. ${ }^{8}$ The main subtype classification system is gene expression profile-based by which tumors are classified into 1) the estrogen receptor (ER)-positive (ie, luminal $\mathrm{A}$ and $\mathrm{B}$ ) group $(70 \%), 2)$ the human epidermal growth factor receptor 2 (HER2)-enriched group (15-20\%) or 3) the basal-like [or triple-negative; ER-, progesterone receptor (PR)- and HER2-negative] group (15\%). ${ }^{9}$ Such subtype classification is clinically important in informing treatment options since these subtypes demonstrate variations in their prognosis and treatment responses (Table 1)., Although endocrine therapy is usually effective in most patients with ER-positive tumors, $15-20 \%$ and $30-40 \%$ of all ER-positive tumors exhibit intrinsic and acquired resistance to the therapy, respectively. ${ }^{11}$ Triple-negative breast cancer, the subtype known to possess a more aggressive nature, particularly lacks targeted therapy and is reliant on chemotherapy that is non-specific, ${ }^{12}$ thus creating the need for more selective and effective agents for breast cancer treatment.

Natural products are an important source for the discovery of new anti-cancer agents that may provide longterm cancer control with minimal side effects. ${ }^{13}$ Isolation of paclitaxel from the bark of Pacific yew trees (Taxus brevifolia) or vinblastine and vincristine from the leaves of Madagascar periwinkle plants (Catharanthus rosea) are some of the many examples. ${ }^{14}$ Fish, green tea, medicinal plants and fruits have been explored for their potentials in breast cancer treatment, with Mangifera indica (M. indica) being one example. ${ }^{15}$

M. indica, commonly known as mango, belongs to the Anacardiaceae flowering plant family. ${ }^{16}$ Although initially thought to have originated from India, $M$. indica has been widely cultivated in Southeast Asia. ${ }^{16}$ Different $M$. indica plant parts contain varying types and quantities of phytochemicals ${ }^{17}$ (Table 2), and they have traditionally been exploited for the treatment of several medical conditions, including gastrointestinal, genitourinary, ophthalmic and respiratory conditions. ${ }^{18,19}$ Preclinical studies on the extracts prepared from various plant parts have demonstrated anti-cancer, anti-inflammatory, antimicrobial, antioxidant and immunomodulatory activities. ${ }^{16,20-23}$ Specifically, various studies have reported on the anticancer activities of $M$. indica pulp extracts in breast cancer, ${ }^{24-26}$ thus suggesting the consumption of $M$. indica fruits may potentially be beneficial in breast cancer management. Further, the phytochemical profiling of $M$. indica extracts has suggested that their anti-cancer activities are attributed mainly to the polyphenolic contents. ${ }^{27}$ Therefore, the phytochemicals have the potentials to be developed as anti-cancer drugs.

This review described preclinical studies conducted on various $M$. indica extracts and phytochemicals (Figure 1) against breast cancer. The proposed mechanisms for their anti-breast cancer activity were then discussed in detail. Although $M$. indica or its derived products have not been evaluated in clinical studies for breast cancer treatment, they have been clinically evaluated for central nervous system activities, ${ }^{28}$ chronic constipation, ${ }^{29}$ gastrointestinal and upper respiratory tract infections ${ }^{30}$ and rheumatoid arthritis, ${ }^{31}$ etc. Hence, future research directions are addressed in order to further explore this medicinal plant and its phytochemicals against breast cancer.

Table I Typical Systemic Therapeutic Options for the Three Major Molecular Subtypes of Breast Cancer

\begin{tabular}{|c|c|c|c|}
\hline & Luminal ER-Positive & HER2-Enriched & Basal-Like (or Triple-Negative) \\
\hline Endocrine therapy & For all patients & For patients with ER-positive tumors & $N / A$ \\
\hline HER2-targeted therapy & $N / A$ & For all patients & $\mathrm{N} / \mathrm{A}$ \\
\hline Chemotherapy & For certain patients & For all patients & For all patients \\
\hline
\end{tabular}

Abbreviations: ER, estrogen receptor; HER2, human epidermal growth factor receptor 2. 
Table 2 Type of Compounds Identified from Different Parts of $M$. indica

\begin{tabular}{|c|c|c|c|}
\hline $\begin{array}{l}\text { M. } \\
\text { indica } \\
\text { parts }\end{array}$ & Types of Extract & Compounds & References \\
\hline Bark & Water & $\begin{array}{l}\text { Polyphenols } \\
\text { Flavan-3-ols [(+)-catechin and (-)-epicatechin }] \\
\text { Phenolic acids (gallic acid and 3,4-dihydroxybenzoic } \\
\text { acid) } \\
\text { Phenolic esters (methyl gallate, propyl gallate and } \\
\text { propyl benzoate) } \\
\text { Xanthones (mangiferin) } \\
\text { Fatty acids } \\
\text { Microelements } \\
\text { Steroids } \\
\text { Terpenoids }\end{array}$ & $\begin{array}{l}\text { Rodeiro et al }(2007)^{32} \\
\text { Núñez Sellés et al }(2002)^{33}\end{array}$ \\
\hline Kernel & Ethanol & $\begin{array}{l}\text { I-Butanol, 3-methyl-, acetate } \\
\text { Butane, I,I-diethoxy-3-methyl- } \\
\text { Propane, I,I,3-triethoxy- } \\
\text { Ethaneperoxoic acid, I-cyano-I-(2-methylphenyl) } \\
\text { ethyl ester } \\
\text { Apigenin 7-glucoside } \\
\text { Disperse Red II } \\
\text { Phenol, 4,6-di(I,I-dimethylethyl)-2-methyl- } \\
\text { (butylated hydroxytoluene, BHT) } \\
\text { Chlorazanil } \\
\text { Isoheptadecanol (I-hexadecanol,2-methyl) } \\
\text { cis-5-Dodecenoic acid, (3-cyanopropyl) dimethylsilyl } \\
\text { ester } \\
\text { Fumaric acid, 2-decyl undecyl ester } \\
\text { Phthalic acid, hept-2-yl isohexyl ester }\end{array}$ & Abdullah et al $(2014)^{39}$ \\
\hline Leaves & $\begin{array}{l}\text { Ethanol } \\
50 \% \mathrm{CO}_{2}: 25 \% \text { ethanol: } 25 \% \text { water } \\
50 \% \text { ethanol: } 50 \% \text { water } \\
50 \% \text { ethanol: } 50 \% \text { water fraction } \\
\text { previously extracted with supercritical- } \\
\mathrm{CO}_{2}\end{array}$ & $\begin{array}{l}\text { Gallic acid } \\
\text { 3,4-Dihydroxybenzoic acid } \\
\text { Maclurin glucoside } \\
\text { Methyl gallate } \\
\text { Iriflophenone 3-C- } \beta \text {-D-glucoside } \\
\text { Iriflophenone 3-C-(2-O-p-hydroxybenzoyl)- } \beta \text {-D- } \\
\text { glucoside } \\
\text { Mangiferin } \\
\text { Homomangiferin } \\
\text { Iriflophenone 3-C-(2-6-di-O-galloyl)- } \beta \text {-D-glucoside } \\
\text { Iriflophenone 3-C-(2-O-galloyl)- } \beta \text {-D-glucoside } \\
\text { tetra-O-galloyl-glucose } \\
\text { Quercetin 3-D-galactoside } \\
\text { Quercetin 3- } \beta \text {-D-glucoside } \\
\text { Quercetin 3-O-xyloside } \\
\text { Quercetin 3-O- } \alpha \text {-L arabinopyranoside } \\
\text { Penta-O-galloyl-glucose }\end{array}$ & Fernández-Ponce et al $(2017)^{27}$ \\
\hline
\end{tabular}

(Continued) 
Table 2 (Continued).

\begin{tabular}{|c|c|c|c|}
\hline $\begin{array}{l}\text { M. } \\
\text { indica } \\
\text { parts }\end{array}$ & Types of Extract & Compounds & References \\
\hline Pulp & $\begin{array}{l}\text { Homogenisation of pulp with ethanol: } \\
\text { methanol: acetone }(1: 1: 1) \text { mixture and } \\
\text { combining of both } \mathrm{C}_{18} \text {-bounded and } \\
\text { ethyl acetate fractions of the resulting } \\
\text { extract }\end{array}$ & $\begin{array}{l}\text { Gallic acid } \\
\text { Gallotannins } \\
\text { Mono-galloyl glucoside } \\
\text { tetra-Galloyl glucoside } \\
\text { penta-Galleo glucoside } \\
\text { OH-benzoic acid hexoside }\end{array}$ & Banerjee et al $(2015)^{24}$ \\
\hline $\begin{array}{l}\text { Peel } \\
\text { and } \\
\text { pulp }\end{array}$ & Methanol & $\begin{array}{l}\text { Phenolic acids } \\
\text { Gallic acid and derivatives (methyl gallate, methyl } \\
\text { galloyl gallate and digallic acid) } \\
\text { Flavonoids } \\
\text { Quercetin and derivatives } \\
\text { Kaempferol } \\
\text { Mangiferin and isomers } \\
\text { Epicatechin-3-O-gallate } \\
\text { Fatty acids and derivatives }\end{array}$ & Pierson et al $(2014)^{54}$ \\
\hline Peel & Ethanol & $\begin{array}{l}\text { Chlorogenic acid } \\
\text { Caffeic acid } \\
\text { Catechin } \\
\text { 3,4-Dicaffeoyl quinic acid } \\
\text { 4,5-Dicaffeoyl quinic acid } \\
\text { Gallic acid } \\
\text { Quercetin }\end{array}$ & Shaban et al $(2016)^{51}$ \\
\hline
\end{tabular}

\section{Methods}

Relevant literature was collected from several scientific databases, including PubMed, Scopus and Google Scholar. The literature search was achieved using the following keywords: "Mango OR Mangifera indica OR Mangiferin AND Breast Cancer". Papers not written in the English language or without abstracts were excluded from initial screening. Any duplicate was also excluded. Following complete screening and selection of appropriate articles, the yielded information was summarised for 1) the anti-cancer activities of $M$. indica extracts or their phytochemicals in in vitro and in vivo breast cancer models and 2) the potential mechanisms underlying the bioactivities. All key findings from the selected articles were summarised in Table 3 and detailed in the following sections.

\section{Effect of Extracts of Various $M$. indica Parts Against Breast Cancer Bark Extract of $M$. indica}

Vimang is an aqueous $M$. indica bark extract consisting of a mixture of polyphenols, fatty acids (FAs), microelements, steroids and terpenoids. ${ }^{32,33}$ It is a registered anti-inflammatory phytomedicine used either as cream, tablets or syrup in Cuba, where its industrial-scale production has been carried out. $^{34,35}$ Vimang has shown various pharmacological activities such as analgesic, anti-cancer, anti-inflammatory, antioxidant and immunomodulatory activities. ${ }^{23,36,37}$ One of its popular uses in Cuba is to improve the quality of life of cancer patients, thus suggesting its potential use in cancer treatment. ${ }^{38}$ A study showed that Vimang can significantly inhibit the proliferation of MDA-MB-231 (triple-negative) cells in a dose-dependent manner, with half-maximal inhibitory concentration $\left(\mathrm{IC}_{50}\right)$ at $259 \mu \mathrm{g} / \mathrm{mL} .^{34}$

\section{Kernel Extract of $M$. indica}

A relevant study reported the ability of $M$. indica kernel extract to induce a dose-dependent reduction in the viability of MCF-7 (luminal A; ER-positive, PR-positive, HER2-negative), MDA-MB-231 and MCF-10A (normal human mammary epithelial cell line) cells. ${ }^{39}$ The $\mathrm{IC}_{50}$ values of kernel extract were significantly lower for the cancer cells $(15 \mu \mathrm{g} / \mathrm{mL}$ for MCF-7 and $30 \mu \mathrm{g} / \mathrm{mL}$ for MDA-MB-231 cells) than the normal cells $(149 \mu \mathrm{g} / \mathrm{mL})$, 


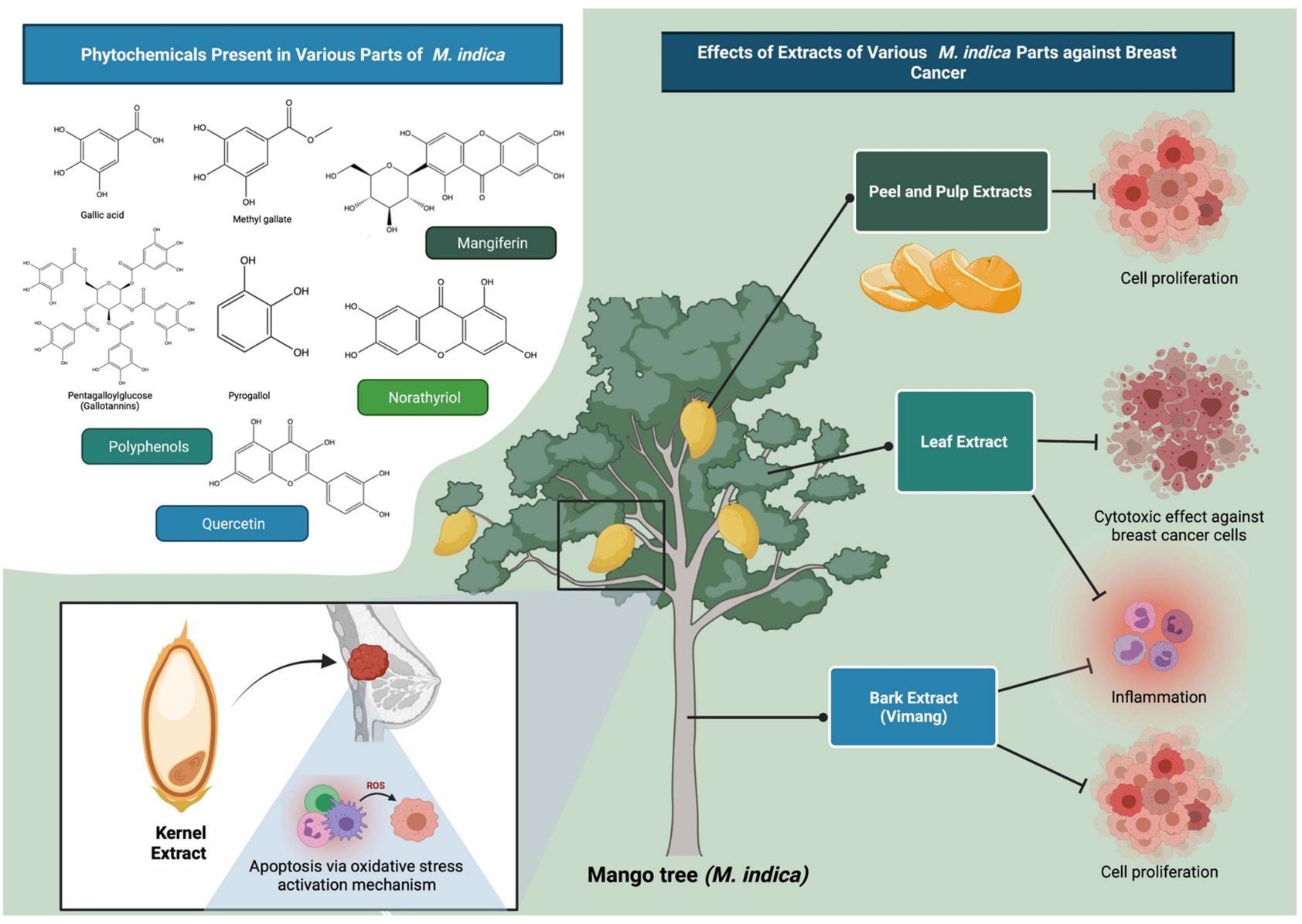

Figure I An overview of effects of $M$. indica extracts and their phytochemicals against breast cancer. Extracts of various $M$. indica parts (bark, kernel, leaves, peel and pulp) have been used to treat a variety of medical problems including breast cancer; as these plant parts contain varying types and amounts of polyphenols, some of which possess anti-proliferative and pro-apoptotic activities. According to phytochemical profile analysis, the anti-cancer activity of $M$. indica extracts is mostly attributable to the presence of polyphenolic compounds such as mangiferin, gallotannins, gallic acid, pyrogallol, methyl gallate and quercetin.

suggesting that the kernel extract is cancer cell-selective. ${ }^{39}$ Subsequent phytochemical profiling of the extract detected 12 major compounds, ${ }^{39}$ some of which have demonstrated anti-breast cancer potentials in previous studies. ${ }^{40-47}$

\section{Leaf Extract of $M$. indica}

An emerging body of evidence has suggested the association between chronic inflammation and cancer risk. ${ }^{48} \mathrm{M}$. indica leaf tea has traditionally been used to ameliorate inflammation. ${ }^{27}$ The polyphenols believed to be the major contributors to $M$. indica's anti-cancer activity are present mainly in the bark and leaves. ${ }^{49}$ Nevertheless, to date, cancer-related studies have generally been focussed on $M$. indica bark, peel and pulp extracts. A study revealed the cytotoxic effect of ethanolic $M$. indica leaf extract $(200 \mu \mathrm{g} / \mathrm{mL})$ on BT474 (luminal B; ER-/PR-/HER2-positive) cells. ${ }^{50}$ In another study, it was observed that while PEW (50\% ethanol:50\% water) and FEW (50\% ethanol:50\% water fraction previously extracted with supercritical carbon dioxide) extracts $(0.01-10 \mu \mathrm{g} / \mathrm{mL})$ with a higher methyl gallate and homomangiferin content are more cytotoxic to MDA-MB231 cells, PET (pure ethanol) and CEW (50\% carbon dioxide: $25 \%$ ethanol: $25 \%$ water) extracts $(0.01-0.1 \mu \mathrm{g} / \mathrm{mL})$ with a higher gallotannin content are more cytotoxic to MCF-7 cells. $^{27}$ This observation suggests that phytochemicals can influence the selectivity of extracts towards different subtypes of breast cancer cells. ${ }^{27}$ Additionally, PET, CEW, PEW and FEW extracts caused only slight reduction in the viability of MCF-10 cells, suggesting that the leaf extracts are cancer cell-selective. $^{27}$

\section{Peel and Pulp Extracts of $M$. indica}

The anti-breast cancer activities of $M$. indica peel and pulp extracts have been more frequently reported compared to the other plant parts. García-Solís et $\mathrm{al}^{25}$ reported the ability of aqueous $M$. indica pulp extract $(4 \% \mathrm{v} / \mathrm{v})$ to 
Table 3 A Summary of in vitro and in vivo Studies of M. indica Extracts and Their Phytochemicals Evaluated for Anti-Breast Cancer Potentials

\begin{tabular}{|c|c|c|c|c|}
\hline $\begin{array}{l}\text { Extracts/ } \\
\text { Phytochemicals }\end{array}$ & Cell Lines/Animals (Sex) & Observations & Mechanism of Action & References \\
\hline Bark & MDA-MB-23I cell line & $\downarrow$ Cell proliferation & Inhibition of NFאB signalling pathway & $\begin{array}{l}\text { García-Rivera et al } \\
(201 \mathrm{I})^{34}\end{array}$ \\
\hline \multirow[t]{3}{*}{ Kernel } & $\begin{array}{l}\text { MCF-7 cell line } \\
\text { MDA-MB-23I cell line }\end{array}$ & $\downarrow$ Cell viability & N/A & $\begin{array}{l}\text { Abdullah et al } \\
(20 \mid 4)^{39}\end{array}$ \\
\hline & MCF-7 cell line & $\begin{array}{l}\uparrow \text { ROS and MDA levels } \\
\downarrow \text { GSH level } \\
\uparrow \text { p53 level } \\
\uparrow \text { Pro-apoptotic markers (Bax and } \\
\text { cytochrome c) } \\
\downarrow \text { Pro-survival markers (Bcl-2) } \\
\uparrow \text { Caspases 7, } 8 \text { and } 9 \text { activities }\end{array}$ & Activation of oxidative stress-induced cell death & $\begin{array}{l}\text { Abdullah et al } \\
(2015 a)^{160}\end{array}$ \\
\hline & MDA-MB-23I cell line & $\begin{array}{l}\uparrow \text { ROS and MDA levels } \\
\downarrow \text { GSH level } \\
\uparrow \mathrm{p} 53 \text { level } \\
\uparrow \text { Pro-apoptotic markers (Bax and } \\
\text { cytochrome c) } \\
\downarrow \text { Pro-survival markers (Bcl-2) } \\
\uparrow \text { Caspases 3,8 and } 9 \text { activities }\end{array}$ & Activation of oxidative stress-induced cell death & $\begin{array}{l}\text { Abdullah et al } \\
(20 \mid 5 b)^{161}\end{array}$ \\
\hline \multirow[t]{2}{*}{ Leaves } & BT-474 cell line & $\downarrow$ Cell viability & $\mathrm{N} / \mathrm{A}$ & $\begin{array}{l}\text { Ganogpichayagrai } \\
\text { et al }(20 \mid 7)^{50}\end{array}$ \\
\hline & $\begin{array}{l}\text { MCF-7 cell line } \\
\text { MDA-MB-23I cell line }\end{array}$ & $\downarrow$ Cell viability & Antioxidant activity & $\begin{array}{l}\text { Fernández-Ponce } \\
\text { et al }(2017)^{27}\end{array}$ \\
\hline \multirow[t]{2}{*}{ Pulp } & MCF-7 cell line & $\downarrow$ Cell proliferation & Antioxidant activity & $\begin{array}{l}\text { García-Solís et al } \\
(2009)^{25}\end{array}$ \\
\hline & $\begin{array}{l}\text { BT- } 474 \text { cell line } \\
\text { Mice bearing BT- } 474 \\
\text { xenografts (female) }\end{array}$ & $\begin{array}{l}\downarrow \text { Cell proliferation } \\
\downarrow \text { Tumor volume }\end{array}$ & $\begin{array}{l}\text { Suppression of } \mathrm{PI} 3 \mathrm{~K} / \mathrm{AKT} \text { pathway } \\
\text { Induction of miR-126 expression }\end{array}$ & $\begin{array}{l}\text { Banerjee et al } \\
(2015)^{24}\end{array}$ \\
\hline \multirow[t]{3}{*}{ Peel and pulp } & MCF-7 cell line & $\downarrow$ Cell viability & Modulation of PPARs & $\begin{array}{l}\text { Wilkinson et al } \\
(2011)^{26}\end{array}$ \\
\hline & $\begin{array}{l}\text { MCF-7 cell line } \\
\text { MDA-MB-23I cell line }\end{array}$ & $\begin{array}{l}\downarrow \text { Cell viability (peel extract only) } \\
\uparrow \text { Cell death (peel extract only) }\end{array}$ & $\mathrm{N} / \mathrm{A}$ & $\begin{array}{l}\text { Hoang et al } \\
(2015)^{52}\end{array}$ \\
\hline & MCF-7 cell line & $\downarrow$ Cell viability (peel extract only) & Modulation of intracellular $\mathrm{Ca}^{2+}$ signalling & Taing et al $(2015)^{53}$ \\
\hline Peel & MCF-7 cell line & $\downarrow$ Cell viability & $\begin{array}{l}\text { Antioxidant activity } \\
\text { Inhibition of aromatase enzymatic activity and } \\
\text { expression }\end{array}$ & $\begin{array}{l}\text { Shaban et al } \\
(2016)^{51}\end{array}$ \\
\hline \multirow[t]{3}{*}{ Polyphenols } & MDA-MB-23I cell line & $\downarrow$ Cell growth & Antioxidant activity & $\begin{array}{l}\text { Noratto et al } \\
(2010)^{55}\end{array}$ \\
\hline & MCFIODCIS cell line & $\downarrow$ Cell proliferation & Suppression of PI3K/AKT pathway & $\begin{array}{l}\text { Nemec et al } \\
(2016)^{56}\end{array}$ \\
\hline & $\begin{array}{l}\text { Mice bearing MCFIODCIS } \\
\text { xenografts (female) }\end{array}$ & $\downarrow$ Tumor volume & $\begin{array}{l}\text { Suppression of PI3K/AKT pathway } \\
\text { Activation of AMPK signalling pathway }\end{array}$ & $\begin{array}{l}\text { Nemec et al } \\
(2017)^{57}\end{array}$ \\
\hline
\end{tabular}

(Continued) 
Table 3 (Continued).

\begin{tabular}{|c|c|c|c|c|}
\hline $\begin{array}{l}\text { Extracts/ } \\
\text { Phytochemicals }\end{array}$ & Cell Lines/Animals (Sex) & Observations & Mechanism of Action & References \\
\hline \multirow[t]{7}{*}{ Mangiferin } & $\begin{array}{l}\text { MCF-7 cell line } \\
\text { T47D cell line } \\
\text { MDA-MB-23I cell line } \\
\text { BT-549 cell line } \\
\text { Mice bearing MDA-MB-23I } \\
\text { xenografts (female) }\end{array}$ & $\begin{array}{l}\downarrow \text { Cell proliferation } \\
\uparrow \text { Apoptosis } \\
\downarrow \text { Cell migration } \\
\downarrow \text { Cell invasion } \\
\downarrow \text { Tumor volume } \\
\downarrow \text { Tumor weight }\end{array}$ & Inactivation of $\beta$-catenin pathway & Li et al $(2013)^{66}$ \\
\hline & $\begin{array}{l}\text { MCF-7 cell line } \\
\text { MDA-MB-23I cell line }\end{array}$ & $\begin{array}{l}\downarrow \text { Cell viability } \\
\downarrow \text { Cell migration } \\
\downarrow \text { Cell invasion }\end{array}$ & Inhibition of RacI/WAVE2 signalling pathway & Deng et al $(2018)^{67}$ \\
\hline & MCF-7 cell line & $\begin{array}{l}\downarrow \text { Cell viability } \\
\downarrow \text { Proliferation marker (PCNA) } \\
\downarrow \text { Pro-survival markers (Bcl-2) } \\
\uparrow \text { Pro-apoptotic markers (Bax, caspase } \\
9 \text { and p27) } \\
\downarrow \text { Cell migration }\end{array}$ & $\begin{array}{l}\text { Inhibition of HMG-CoA reductase, proteasome } \\
\text { and plasmin enzymatic activities }\end{array}$ & $\begin{array}{l}\text { Cuccioloni et al } \\
(2016)^{68}\end{array}$ \\
\hline & MCF-7 cell line & $\downarrow$ Cell viability & N/A & $\begin{array}{l}\text { Louisa et al } \\
(2014)^{74}\end{array}$ \\
\hline & MDA-MB-23I cell line & $\leftrightarrow$ Cell viability & Inhibition of $N F \kappa B$ signalling pathway & $\begin{array}{l}\text { García-Rivera et al } \\
(2011)^{34}\end{array}$ \\
\hline & MCF-7 cell line & $\leftrightarrow$ Cell viability & Modulation of ER activity & $\begin{array}{l}\text { Wilkinson et al } \\
(2015)^{75}\end{array}$ \\
\hline & MCF-7 cell line & N/A & Inhibition of NFKB signalling pathway & $\begin{array}{l}\text { Sarkar et al } \\
(2004)^{228}\end{array}$ \\
\hline Norathyriol & MCF-7 cell line & $\downarrow$ Cell viability & Modulation of ER activity & $\begin{array}{l}\text { Wilkinson et al } \\
(2015)^{75}\end{array}$ \\
\hline \multirow[t]{2}{*}{$\begin{array}{l}\text { Gallotannin } \\
(5 G G)\end{array}$} & MCF-7 cell line & $\downarrow$ Cell growth & $\begin{array}{l}\text { Suppression of PI3K/AKT pathway } \\
\text { Modulation of ER activity }\end{array}$ & Hua et al (2006) $)^{94}$ \\
\hline & MCF-7 cell line & $\begin{array}{l}\downarrow \text { Cell growth } \\
\uparrow \text { GI-phase arrest }\end{array}$ & Modulation of cell cycle regulators & $\begin{array}{l}\text { Chen et al } \\
(2003)^{95}\end{array}$ \\
\hline \multirow[t]{4}{*}{ Gallic acid } & MDA-MB-23I cell line & $\downarrow$ Cell viability & Inhibition of NFKB signalling pathway & $\begin{array}{l}\text { García-Rivera et al } \\
(2011)^{34}\end{array}$ \\
\hline & MCF-7 cell line & $\begin{array}{l}\downarrow \text { Cell proliferation } \\
\uparrow \text { S-phase and G2/M-phase arrest }\end{array}$ & Modulation of cell cycle regulators & Hsu et al $(2011)^{111}$ \\
\hline & MCFIODCIS cell line & $\downarrow$ Cell proliferation & N/A & $\begin{array}{l}\text { Nemec et al } \\
(2016)^{56}\end{array}$ \\
\hline & MCF-7 cell line & $\begin{array}{l}\downarrow \text { Cell growth } \\
\uparrow \text { Apoptosis } \\
\uparrow \text { Fas, FasL levels and caspase 8 } \\
\text { activity } \\
\downarrow \Delta \Psi_{\mathrm{m}} \\
\uparrow \text { Bax/Bcl-2 ratio, cytochrome c level } \\
\text { and caspase 9 activity } \\
\uparrow \text { Caspase 8-mediated Bid cleavage }\end{array}$ & N/A & $\begin{array}{l}\text { Ke Wang et al } \\
(2014)^{112}\end{array}$ \\
\hline
\end{tabular}

(Continued) 
Table 3 (Continued).

\begin{tabular}{|c|c|c|c|c|}
\hline $\begin{array}{l}\text { Extracts/ } \\
\text { Phytochemicals }\end{array}$ & Cell Lines/Animals (Sex) & Observations & Mechanism of Action & References \\
\hline \multirow[t]{2}{*}{ Pyrogallol } & MCFIODCIS cell line & $\downarrow$ Cell proliferation & Suppression of PI3K/AKT pathway & $\begin{array}{l}\text { Nemec et al } \\
(2016)^{56}\end{array}$ \\
\hline & $\begin{array}{l}\text { Mice bearing MCFIODCIS } \\
\text { xenografts (female) }\end{array}$ & $\downarrow$ Tumor volume & $\begin{array}{l}\text { Suppression of PI3K/AKT pathway } \\
\text { Activation of AMPK signalling pathway }\end{array}$ & $\begin{array}{l}\text { Nemec et al } \\
(2017)^{57}\end{array}$ \\
\hline Methyl gallate & MCFIODCIS cell line & $\downarrow$ Cell proliferation & N/A & $\begin{array}{l}\text { Nemec et al } \\
(2016)^{56}\end{array}$ \\
\hline \multirow[t]{5}{*}{ Quercetin } & MCF-7 cell line & $\downarrow$ Cell viability & Modulation of ER activity & $\begin{array}{l}\text { Wilkinson et al } \\
(2015)^{75}\end{array}$ \\
\hline & MCF-7 cell line & $\begin{array}{l}\downarrow \text { Cell growth } \\
\uparrow \text { Apoptosis } \\
\uparrow \text { S-phase arrest }\end{array}$ & Activation of oxidative stress-induced cell death & $\begin{array}{l}\text { Zhang et al } \\
(2012)^{147}\end{array}$ \\
\hline & MCF-7 cell line & $\begin{array}{l}\downarrow \text { Cell viability } \\
\uparrow \text { Apoptosis } \\
\uparrow \text { S-phase arrest } \\
\uparrow \text { ATF6, GRP78, PERK and GADDI53 } \\
\text { levels } \\
\downarrow \Delta \Psi_{\mathrm{m}} \\
\uparrow \text { AIF, Bid, caspase 6, caspase 8, } \\
\text { caspase 9, Fas and TRAIL levels } \\
\downarrow \text { Bcl-2, PARP and XIAP levels } \\
\uparrow \text { Caspases 6, 8 and 9 activities } \\
\uparrow \text { AIF and GADDI53 nuclear } \\
\text { translocation }\end{array}$ & $\begin{array}{l}\text { Modulation of intracellular } \mathrm{Ca}^{2+} \text { signalling } \\
\text { Modulation of cell cycle regulators }\end{array}$ & $\begin{array}{l}\text { Chou et al } \\
(2010)^{148}\end{array}$ \\
\hline & MDA-MB-23I cell line & $\begin{array}{l}\downarrow \text { Cell viability } \\
\uparrow \text { Apoptosis } \\
\uparrow \text { G2/M-phase arrest } \\
\uparrow \text { ATF6- } \alpha \text {, GRP78 and PERK levels } \\
\downarrow \text { Pro-caspase } 3 \\
\downarrow \Delta \Psi_{\mathrm{m}} \\
\uparrow \text { Bax, caspase 3, caspase 8, } \\
\text { cytochrome c and Fas levels } \\
\downarrow \text { PARP and XIAP levels } \\
\uparrow \text { Caspases } 3,8 \text { and } 9 \text { activities } \\
\uparrow \text { AlF level and mitochondrio-nuclear } \\
\text { translocation }\end{array}$ & $\begin{array}{l}\text { Modulation of intracellular } \mathrm{Ca}^{2+} \text { signalling } \\
\text { Modulation of cell cycle regulators }\end{array}$ & $\begin{array}{l}\text { Chien et al } \\
(2009)^{149}\end{array}$ \\
\hline & $\begin{array}{l}\text { MDA-MB-23I cell line } \\
\text { Mice bearing MDA-MB-23I } \\
\text { xenografts (female) }\end{array}$ & $\begin{array}{l}\downarrow \text { Cell proliferation } \\
\uparrow \text { Apoptosis } \\
\uparrow \text { G2/M-phase arrest } \\
\uparrow \text { Caspases } 3 \text { and } 7 \text { activities } \\
\downarrow \text { Cell migration } \\
\downarrow \text { Tumor growth }\end{array}$ & $\begin{array}{l}\text { Suppression of PI3K/AKT pathway } \\
\text { Activation of AMPK signalling pathway }\end{array}$ & $\begin{array}{l}\text { Rivera Rivera et al } \\
(2016)^{150}\end{array}$ \\
\hline
\end{tabular}

Notes: $\uparrow$ increased; $\downarrow$ decreased; $\leftrightarrow$ no significant change.

Abbreviations: AIF, apoptosis-inducing factor; AMPK, AMP-activated protein kinase; ATF6- $\alpha$, AMP-dependent transcription factor 6-alpha; Bax, Bcl-2-associated X protein; Bcl-2, B-cell lymphoma 2; Bid, BH3-interacting domain death agonist; $\mathrm{Ca}^{2+}$, calcium; ER, estrogen receptor; Fas, Fas cell surface death receptor; FasL, Fas ligand; GADDI53, growth arrest and DNA damage I53; GRP78, 78-kDa glucose-regulated protein; GSH, glutathione; HMG-CoA reductase, 3-hydroxy-3-methyl-glutaryl-coenzyme A; MDA, malondialdehyde; miR-126, microRNA-126; $\triangle \Psi_{m}$, mitochondrial membrane potential; NFKB, nuclear factor kappa-light-chain-enhancer of activated B cells; PARP, Poly-ADP ribose polymerase; PCNA, proliferating cell nuclear antigen; PERK, protein kinase RNA-like endoplasmic reticulum kinase; PI3K/AKT, phosphoinositide 3-kinase/protein kinase B; PPARs, peroxisome proliferator-activated receptors; ROS, reactive oxygen species; TRAIL, tumor necrosis factor-related apoptosis-inducing ligand; XIAP, X-linked inhibitor of apoptosis protein; 5GG, pentagalloylglucose. 
induce a significant reduction in MCF-7 cell proliferation. In other studies, Wilkinson et $\mathrm{al}^{26}$ and Shaban et $\mathrm{al}^{51}$ observed a significant reduction in MCF-7 cell viability following treatment with ethyl acetate fractions prepared from $M$. indica peels and pulps as well as ethanolic $M$. indica peel extract, respectively. On the other hand, Banerjee et $\mathrm{al}^{24}$ reported the ability of $M$. indica pulp extract (2.5-20.0 mg GAE/L) to dose-dependently inhibit BT-474 cell proliferation. In the same study, $M$. indica pulp extract ( $0.8 \mathrm{mg}$ GAE/day; 35 days) also significantly reduced tumor volume in nude mice bearing BT-474 xenografts.

As different $M$. indica varieties have different phytochemical profiles and bioactivities, two studies have evaluated the anti-breast cancer activities of methanolic peel and pulp extracts prepared from three $M$. indica varieties (Irwin, Kensington Pride and Nam Doc Mai). ${ }^{52,53}$ Both studies consistently reported Nam Doc Mai peel extract as the only extract with significant cytotoxicity against MCF-7 cells. Additionally, only Nam Doc Mai peel extract was observed to possess significant cell-death inducing activity in MDA-MB-231 cells. ${ }^{52}$ Previous phytochemical profiling of $M$. indica peel and pulp extracts revealed that Nam Doc Mai peel extract uniquely contained gallic acid and galloylated derivatives as well as a higher level of methyl gallate,54 which may explain its higher bioactivities.

\section{Effect of Phytochemicals from $M$. indica Against Breast Cancer Polyphenols}

The anti-cancer activity of $M$. indica has frequently been attributed to its polyphenolic content. Noratto et $\mathrm{al}^{55}$ reported that the polyphenolic extracts prepared from different $M$. indica varieties suppressed MDA-MB-231 cell growth in a dose-dependent manner. In another study conducted by Nemec et al, ${ }^{56}$ a low molecular weight fraction of $M$. indica polyphenols $(1 \mathrm{mg} / \mathrm{L})$ was found to significantly reduce the proliferation of MCF10DCIS [a ductal carcinoma in situ (DCIS) model cell line] cells. In the same study, combined treatment with $M$. indica polyphenols and a conventional anti-cancer agent [5-fluorouracil (5-FU)] demonstrated a greater anti-proliferative effect on MCF10DCIS cells than either treatment alone, which is suggestive of a synergistic effect. The same research group did a follow-up study on the in vivo anti-cancer effects of $M$. indica polyphenols $(0.8 \mathrm{mg}$ GAE/day; 4 weeks) in nude mice carrying MCF10DCIS xenografts, whereby a reduction in tumor volume $(>70 \%)$ was observed following treatment. ${ }^{57}$

Various studies have investigated into the anti-breast cancer activities of individual $M$. indica polyphenols, instead of $M$. indica polyphenolic mixtures, as described below.

\section{Mangiferin}

Mangiferin (1,3,6,7-tetrahydroxyxanthone-C2- $\beta$-D-glucoside), a plant natural xanthonoid, is the predominant phytochemical found in various $M$. indica parts, including bark, fruits, leaves and roots. ${ }^{58,59}$ Mangiferin has been reported to exhibit various pharmacological activities such as analgesic, anti-bacterial, anti-cancer, anti-diabetic, anti-inflammatory, antioxidant and immunomodulatory activities. $^{59-64}$ Importantly, mangiferin has shown protective effects against various types of cancers, including breast cancer. ${ }^{65}$

As reported by $\mathrm{Li}$ et al, ${ }^{66}$ mangiferin $(75-300 \mu \mathrm{M})$ caused a dose-dependent reduction in the proliferation of ER-positive (MCF-7 and T47D) and ER-negative (MDAMB-231 and BT-549) breast cancer cells, which may be attributed to an increase in apoptosis. In the same study, mangiferin (12.5-50.0 $\mu \mathrm{M})$ also demonstrated dose-dependent anti-migratory and anti-invasive effects on highly metastatic MDA-MB-231 and BT-549 cells. When the in vivo anticancer activity of mangiferin $(100 \mathrm{mg} / \mathrm{kg} / \mathrm{day} ; 5$ weeks) was evaluated in severe-combined immunodeficiency (SCID) mice bearing MDA-MB-231 xenografts, significant reduction in both tumor volume and tumor weight was observed. ${ }^{66}$

The cytotoxic, anti-migratory and anti-invasive effects of mangiferin $(10-50 \mu \mathrm{M})$ have similarly been reported in another study by Deng et al, ${ }^{67}$ whereby a dose-dependent reduction in the viability of MCF-7 and MDA-MB-231 cells as well as a significant reduction in the migration and invasion of MDA-MB-231 cells were observed. Notably, mangiferin has also been reported by Cuccioloni et $\mathrm{al}^{68}$ to be cancer cell-selective, as evidenced by the observations of greater decreases in cell viability, proliferating cell nuclear antigen (PCNA; a marker of cell proliferation) level and anti-apoptotic protein [B-cell lymphoma 2 $(\mathrm{Bcl}-2)]$ level as well as greater increases in pro-apoptotic protein [Bcl-2-associated $\mathrm{X}$ protein (Bax), caspase 9 and p27] levels in MCF-7 cells than MCF-10A cells following treatment. The same study also showed that mangiferin could suppress plasmin-induced increase in $\mathrm{MCF}-7$ and MCF-10A cell migration. 
Doxorubicin, an anthracycline drug, has been used routinely for the treatment of various cancers, including breast cancer. ${ }^{69}$ However, its use has been limited mainly due to cardiotoxicity and resistance. ${ }^{70}$ One of the causes of doxorubicin resistance is the increased expression of drug efflux pumps such as P-glycoprotein (Pgp), multidrug resistance-associated protein-1 (MRP-1) and breast cancer resistance protein (BCRP) ${ }^{71-73}$ Louisa et $\mathrm{al}^{74}$ found that mangiferin can increase the sensitivity of MCF-7 cells (pre-treated with doxorubicin) towards doxorubicin treatment, as evidenced by a significant reduction in the viability of MCF-7 cells treated with mangiferin $(10-50 \mu \mathrm{M})$ in combination with doxorubicin. Subsequent evaluation of Pgp, MRP1 and BCRP gene expressions showed that while high dose $(50 \mu \mathrm{M})$ mangiferin could significantly downregulate Pgp, there were no significant changes in the expressions of MRP1 and BCRP at all doses. ${ }^{74}$ These findings thus suggest that high-dose mangiferin can potentially serve as a chemosensitizer for doxorubicin by downregulating Pgp expression. ${ }^{74}$

In contrast to the above-mentioned studies, a number of studies have failed to observe the anti-breast cancer activity of mangiferin, ${ }^{34,75}$ thus warranting further investigation. In one of the studies, Wilkinson et $\mathrm{al}^{75}$ showed that mangiferin is capable of activating ER $\alpha$ but not ER $\beta$, and suggested that the observed lack of anti-proliferative activity of mangiferin may be linked to the differential activation or heterodimer formation of ER $\alpha$ and $\mathrm{ER} \beta$.

\section{Norathyriol}

Norathyriol (1,3,6,7-tetrahydroxyxanthone), an aglycone derivative of mangiferin, is structurally similar to mangiferin except for a C-glucosyl bond. ${ }^{76}$ Ample of evidence has shown that orally consumed mangiferin is firstly subjected to de-glycosylation by intestinal bacterium to form norathyriol prior to being absorbed by the colon, suggesting norathyriol is likely to contribute to the observed bioactivities of mangiferin. ${ }^{77,78}$ Studies focussing on norathyriol have reported a range of pharmacological activities. ${ }^{79-83}$ For example, a study showed that norathyriol $(100 \mu \mathrm{M})$ significantly reduced the viability of MCF-7 cells. ${ }^{75}$

\section{Gallotannins, Gallic Acid, Pyrogallol and Methyl Gallate}

$M$. indica is a rich source of gallotannins and lower molecular weight gallates such as gallic acid. ${ }^{56}$ Although orally consumed gallotannins are un-absorbable owing to their high molecular weight, they can be hydrolysed in the gastrointestinal tract by tannase to release free gallic acid, which can subsequently undergo decarboxylation to pyrogallol via the activity of gallic acid decarboxylase in intestinal microbiota. ${ }^{84,85}$ Gallotannins have been reported to exhibit a wide range of pharmacological activities, including anti-cancer, ${ }^{86-88}$ anti-diabetic, ${ }^{89}$ antiinflammatory, ${ }^{90}$ antimicrobial, ${ }^{91}$ and antioxidant ${ }^{92}$ activities. Pentagalloylglucose (1,2,3,4,6-penta- $O$-galloyl- $\beta$-Dglucose; 5GG), a gallotannin that can be found in $M$. indica, has been investigated for its effects on breast cancer cell lines. ${ }^{93}$ For instance, treatment with 5GG $(0.5-80 \mu \mathrm{M})$ was reported to exhibit growth-inhibitory effect on MCF-7 cells in both time- and dose-dependent manner. ${ }^{94}$ Another study similarly reported the dosedependent growth-inhibitory effect of 5GG $(1-100 \mu \mathrm{M})$ on MCF-7 cells. ${ }^{95}$ Further cell cycle analysis revealed a dramatic increase in G1-phase cell number, suggesting that 5 GG can induce a G1-phase arrest in MCF-7 cells. ${ }^{95}$

Gallic acid (3,4,5-trihydroxybenzoic acid), one of the most abundantly distributed plant phenolic compounds that can be found in certain fruits and medicinal plants, has been used extensively in both food and pharmaceutical industries. ${ }^{96}$ Gallic acid has demonstrated various pharmacological activities. ${ }^{97-101}$ Its anti-cancer activity, in particular, has been extensively studied in various cancer types. ${ }^{102-110}$ In a study, MDA-MB-231 cells treated with gallic acid showed a significant dose-dependent reduction in cell viability, with $\mathrm{IC}_{50}$ at 10 $\mu \mathrm{g} / \mathrm{mL} .{ }^{34}$ Another study reported the ability of gallic acid (110 or $2-12 \mu \mathrm{g} / \mathrm{mL}$ ) to induce a reduction in cell proliferation and an increase in S-phase and G2/M-phase ratios in MCF-7 cells in a dose-dependent manner. ${ }^{111}$ Similarly, the anti-proliferative activity of gallic acid $(1 \mathrm{mg} / \mathrm{L})$ has also been demonstrated in MCF10DCIS cells. ${ }^{56}$

Of note, Ke Wang et al ${ }^{112}$ observed a dose-dependent reduction in MCF-7 cell growth following gallic acid treatment $\left(\mathrm{IC}_{50}: 80.5 \mu \mathrm{M}\right)$ and attributed this effect to apoptosis induction. Subsequent analyses revealed increased Fas cell surface death receptor (Fas) and Fas ligand (FasL) protein levels and caspase 8 activity, suggesting the induction of death receptor apoptotic pathway.${ }^{112}$ Reduced mitochondrial membrane potential $\left(\Delta \Psi_{\mathrm{m}}\right)$ as well as increased $\mathrm{Bax} / \mathrm{Bcl}-2$ ratio, cytosolic cytochrome $\mathrm{c}$ level and caspase 9 activity were also observed, which was suggestive of the induction of mitochondrial apoptotic pathway. ${ }^{112}$ Moreover, caspase 8-mediated Bid cleavage, which is known to be followed by cytochrome c release and caspase 9 activation, was observed in gallic acid- 
treated MCF-7 cells. ${ }^{112}$ Collectively, these findings suggest that gallic acid-induced apoptosis of MCF-7 cells involved both mitochondrial and death receptor pathways as well as a cross-link between the two pathways. ${ }^{112}$

Pyrogallol (1,2,3-trihydroxybenzene), a microbial metabolite of $M$. indica gallotannins, can also be found naturally in many other fruits and vegetables. ${ }^{113}$ Pyrogallol is used commercially mainly in the production of pharmaceuticals and pesticides. ${ }^{114}$ Similar to gallotannins and gallic acid, pyrogallol has been found to possess multiple pharmacological activities ${ }^{113,115,116}$ in addition to anti-carcinogenic properties in various cancer types. ${ }^{117-120}$ For instance, pyrogallol ( $1 \mathrm{mg} / \mathrm{L})$ has been reported to exert anti-proliferative effect on MCF10DCIS cells. ${ }^{56}$ However, pyrogallol at a higher dose $(10 \mathrm{mg} / \mathrm{L})$ was observed to have insignificant cytotoxicity against normal human breast epithelial cells MCF-12F, suggesting its selectivity of action towards cancer cells. $^{56}$ The same research group then studied the in vivo effect of pyrogallol, and found that treatment with pyrogallol $(0.2 \mathrm{mg} /$ day; 4 weeks $)$ significantly reduced tumor volume $(>70 \%)$ in mice bearing MCF10DCIS xenografts. ${ }^{57}$

Methyl gallate (methyl-3,4,5-trihydroxybenzoate), a methyl ester of gallic acid, is naturally found in $M$. indica and various other plants. ${ }^{121-124}$ Methyl gallate possesses a wide range of medicinal properties. ${ }^{122,125-131}$ For instance, methyl gallate $(1 \mathrm{mg} / \mathrm{L})$ was observed to induce a $>40 \%$ reduction in MCF10DCIS cell proliferation. ${ }^{56}$

\section{Quercetin}

Quercetin $\left(3,5,7,3^{\prime}, 4^{\prime}\right.$-pentahydroxyflavone) is a natural flavonoid that can be found abundantly in various fruits and vegetables. ${ }^{132}$ For instance, there have been reports of the presence of quercetin in extracts prepared from $M$. indica leaves, peels and pulps. ${ }^{27,51,54}$ Quercetin possesses a range of bioactive effects that can potentially be beneficial to human health, ${ }^{133-139}$ including its anti-cancer activities in a broad range of cancer types. ${ }^{140-146}$

In a study, Wilkinson et $\mathrm{al}^{75}$ found that quercetin (100 $\mu \mathrm{M})$ can significantly reduce MCF-7 cell viability. Another study by Zhang et $\mathrm{al}^{147}$ reported that quercetin $(25-100 \mu \mathrm{M})$ can inhibit MCF-7 cell growth in both dose- and time-dependent manner via the induction of apoptosis and S-phase arrest. Chou et al ${ }^{148}$ similarly reported the ability of quercetin $(10-175 \mu \mathrm{M})$ to dose- and time-dependently reduce MCF-7 cell viability via the induction of apoptosis and S-phase arrest. Subsequent analyses revealed increased protein levels of cyclic AMP-dependent transcription factor 6-alpha (ATF6), 78-kDa glucose-regulated protein (GRP78), protein kinase RNA-like endoplasmic reticulum kinase (PERK) and growth arrest and DNA damage 153 (GADD153) in quercetin-treated MCF-7 cells, all of which were suggested to be correlated with endoplasmic reticulum (ER) stress. $^{148}$ Furthermore, $\Delta \Psi_{\mathrm{m}}$ loss, increased protein levels of apoptosis-inducing factor (AIF), Bid, caspases 6, 8 and 9, Fas and tumor necrosis factor-related apoptosis inducing ligand (TRAIL), decreased protein levels of Bcl-2, poly-ADP ribose polymerase (PARP) and X-linked inhibitor of apoptosis protein (XIAP), increased activities of caspases 6,8 and 9 as well as increased nuclear translocation of AIF and GADD153 were also observed, indicating the induction of apoptosis possibly in response to ER stress. ${ }^{148}$ Overall, the findings also suggest that quercetin-induced apoptosis in MCF-7 cells is likely to be mediated through both mitochondrial and death receptor pathways. ${ }^{148}$

In another breast cancer cell line (MDA-MB-231 cells), Chien et al $^{149}$ also observed a dose- and time-dependent reduction in cell viability following quercetin treatment $\left(\mathrm{IC}_{50}: 278 \mu \mathrm{M}\right)$. The observed reduction in cell viability can likely be explained by quercetin-induced apoptosis and G2/M-phase arrest, ${ }^{149}$ which contrasted the findings by Zhang et $\mathrm{al}^{147}$ and Chou et al ${ }^{148}$ (ie, S-phase arrest in MCF-7 cells). Findings from the subsequent protein expression analysis of various ER stress and apoptotic markers in quercetin-treated MDA-MB-231 cells were similarly suggestive of the occurrence of ER stress-induced apoptosis and the involvement of two caspase-dependent apoptotic pathways (mitochondrial- and caspase 3-dependent pathways). ${ }^{149}$ Another study also linked the anti-proliferative effect of quercetin $(15 \mu \mathrm{M})$ on MDA-MB-231 cells to the induction of apoptosis and G2/M-phase arrest. ${ }^{150}$ The same study also showed that quercetin exhibited anti-migratory activity against MDA-MB-231 cells. The researchers then evaluated the in vivo anti-cancer activity of quercetin (15 or $45 \mathrm{mg} / \mathrm{kg}$ body weight; thrice weekly for 13 weeks) in SCID mice bearing MDA-MB-231 xenografts, whereby both treatment groups demonstrated significantly reduced $(\sim 70 \%)$ tumor growth. ${ }^{150}$

\section{Overall Anti-Breast Cancer Mechanisms of Action of $M$. indica Extracts and Their Phytochemicals Activation of Oxidative Stress-Induced Cell Death}

Reactive oxygen species (ROS) are by-products of normal cellular metabolism. ${ }^{151}$ They have physiological roles in 
signalling pathway (eg, apoptosis, carcinogenesis and proliferation) stimulation but are very transient due to their high reactivity. ${ }^{152,153}$ This maintenance of cellular redox balance is critical and is achieved via an antioxidant system. ${ }^{154}$ Oxidative stress occurs when ROS production exceeds and depletes the antioxidant defences. ${ }^{155}$ The balance of oxidative stress plays an important role in cancer. While moderately elevated ROS levels can contribute to carcinogenesis, cancer cell survival and metastasis, elevated ROS levels above the toxic threshold can cause cancer cell death usually via apoptosis induction. ${ }^{156-158}$ In recent years, oxidative stress-induced apoptosis has attracted attentions as a potential anti-cancer mechanism. ${ }^{159}$

In a study conducted by Abdullah et $\mathrm{al}^{160}$ ethanolic $M$. indica kernel extract was reported to induce both mitochondrial and death receptor pathways of apoptosis in MCF-7 cells via the induction of oxidative stress and the consequent upregulation of $\mathrm{p} 53$, as evidenced by the observations of dose- and time-dependent increases in ROS generation and malondialdehyde (MDA; a lipid peroxidation product) level as well as decrease in glutathione (GSH; an antioxidant) level in MCF-7 cells treated with the extracts $(5-50 \mu \mathrm{g} / \mathrm{mL})$. A similar study conducted by the same research group also linked the pro-apoptotic effect of ethanolic $M$. indica kernel extracts on MDAMB-231 cells to oxidative stress induction and p53 upregulation. $^{161}$

As reported by Zhang et al, ${ }^{147}$ the exposure of MCF-7 cells to quercetin $(25-100 \mu \mathrm{M})$ dose-dependently caused the rightward-shift of dihydroethidium (DHE) signals and increased dichlorofluorescin diacetate (DCFH-DA) signals, which were suggestive of the stimulation of superoxide anion $\left(\mathrm{O}_{2}{ }^{-}\right)$release and the increased generation of hydrogen peroxide $\left(\mathrm{H}_{2} \mathrm{O}_{2}\right)$, respectively. These findings indicate that quercetin is likely to induce apoptosis in MCF-7 cells by increasing oxidative stress. ${ }^{147}$

\section{Antioxidant Activity}

Moderately elevated ROS level is considered to be protumorigenic, as ROS function as signalling molecules in various pathways (eg, cell differentiation, proliferation, survival and migration) that can ultimately lead to the promotion of cancer initiation and progression. ${ }^{162,163}$ Depleting tumorous cells from these ROS-sensitive signalling pathways via the use of natural antioxidants can therefore potentially be a useful anti-cancer mechanism. ${ }^{164}$

The leaves of $M$. indica are known to contain various families of phenolic compounds that possess potent antioxidant activity. ${ }^{165}$ There have been reports that indicate the subcritical water, water, 50\% ethanol:50\% water, ethanol and 50\% carbon dioxide: $25 \%$ ethanol:25\% water extracts of $M$. indica leaves exhibit a more potent antioxidant activity than $(+)$ - $\alpha$-tocopherol in the 2,2-diphenyl-1picrylhydrazyl radical (DPPH) assay. ${ }^{165,166}$ A study also reported on the antioxidant activities of PET, CEW, PEW and FEW $M$. indica leaf extracts $(0.01-100 \mu \mathrm{g} / \mathrm{mL})$ in non-tumorous (MCF-10A) and tumorous (MCF-7 and MDA-MB-231) cells by detecting changes in intracellular ROS levels, subsequent to the observation of their cytotoxic effects on breast cancer cells. ${ }^{27}$ However, the antioxidant activity was only observed at lower extract concentrations. $^{27}$ At the highest extract concentration (100 $\mu \mathrm{g} / \mathrm{mL})$, all extracts appeared to be pro-oxidant. ${ }^{27}$ The cytotoxic effect observed at this high concentration was thus likely the outcome of oxidative stress-induced cell death. ${ }^{27}$

Studies have also reported on antioxidant activities of $M$. indica peel and pulp extracts. For instance, aqueous $M$. indica pulp extract consistently demonstrated a high antioxidant activity in both DPPH and ferric reducing antioxidant power (FRAP) assays. ${ }^{25}$ Another study confirmed the antioxidant activity of ethanolic $M$. indica peel extract in terms of its anti-lipid peroxidation, DPPH radical scavenging, ferric reducing and nitric oxide (NO) radical scavenging activities via the respective use of thiobarbituric acid reaction, DPPH assay, FRAP assay and Griess' reagent. ${ }^{51}$

Besides, the polyphenolic extracts (10 mg GAE/L) of different $M$. indica varieties have also demonstrated antioxidant potentials in the oxygen radical absorbance capacity (ORAC) assay, and a strong correlation between antioxidant activity and total phenolic content has been noted. ${ }^{55}$ Figure 2 summarises how $M$. indica extracts and phytochemicals exert their anti-cancer effects by activating oxidative stress-induced cell death or acting as antioxidants.

\section{Modulation of Peroxisome Proliferator- Activated Receptors}

Peroxisome proliferator-activated receptors (PPARs), comprising three subtypes (PPAR $\alpha, \operatorname{PPAR} \beta / \delta$ and PPAR $\gamma$ ), are ligand-activated transcription factors belonging to the nuclear hormone receptor superfamily. ${ }^{167}$ PPAR activation occurs in response to the binding of endogenous ligands, including Fas, prostacyclins, prostaglandins and triglycerides. ${ }^{168}$ By binding the peroxisome proliferator responsive elements (PPREs) upstream of their target 


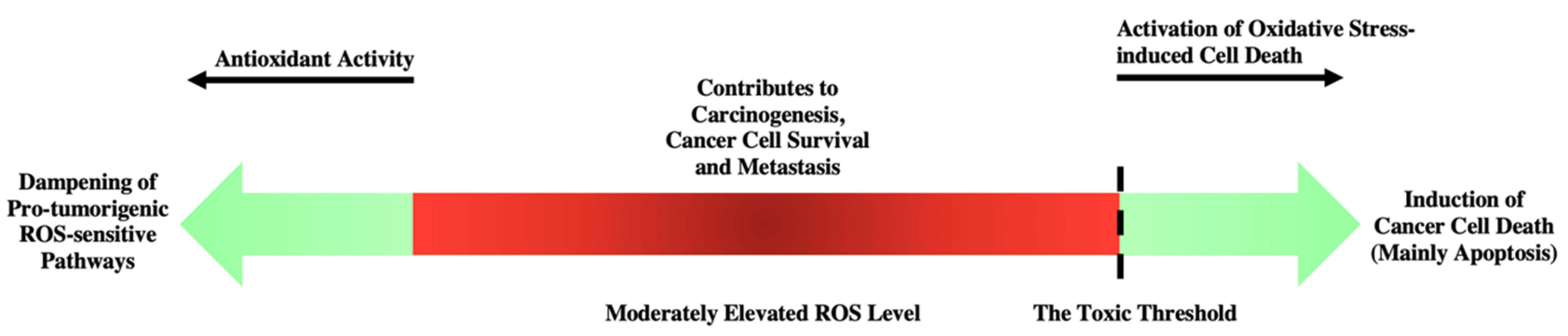

Figure 2 Activation of oxidative stress-induced cell death and antioxidant activity as the anti-cancer mechanisms of $M$. indica extracts and phytochemicals.

genes as a PPAR-retinoid X receptor (RXR) heterodimer, PPARs are able to activate the expressions of genes that are mostly involved in energy homeostasis and metabolic functions. ${ }^{169}$

PPARs have also been implicated in carcinogenesis. Although PPAR $\alpha$ has been linked to hepatocarcinogenesis in rodents, several epidemiological studies suggest that this is unlikely to be observed in humans. ${ }^{170-173}$ On the other hand, while some studies suggest that PPAR $\delta$ may contribute to cancer progression, ${ }^{174-176}$ other studies suggest that PPAR $\delta$ may contribute to cancer suppression.${ }^{177,178}$ Similarly, although PPAR $\gamma$ activation has often been linked to proliferation inhibition and apoptosis induction in cancer cells, ${ }^{179-181}$ various studies have yielded contradictory results that suggest PPAR $\gamma$ activation may promote cancer development. ${ }^{182,183}$

In a study, Wilkinson et $\mathrm{al}^{26}$ reported the ability of $M$. indica peel and pulp ethyl acetate fractions to reduce PPAR activity in Cos-7 cells. However, given the controversy surrounding the consequences of PPAR $\gamma$ activation in cancer, whether the PPAR $\gamma$-inhibitory activity of $M$. indica peel and pulp fractions will be beneficial in breast cancer management requires further evaluation. ${ }^{26}$

\section{Suppression of Phosphoinositide 3- Kinase/Protein Kinase B Pathway}

The phosphoinositide 3-kinase/protein kinase B (PI3K/AKT) pathway can be stimulated in response to the activation of G-protein-coupled receptors (GPCRs) and receptor tyrosine kinases (RTKs) by cytokines, hormones and growth factors.${ }^{184}$ Upon GPCR or RTK activation, PI3K phosphorylates phosphatidylinositol 4, 5-bisphosphate ( $\mathrm{PIP}_{2}$ ) to form phosphatidylinositol 3, 4, 4-triphosphate $\left(\mathrm{PIP}_{3}\right)$ that can, in turn, recruit AKT and phosphoinositide-dependent kinase-1 (PDK-1) to the plasma membrane. ${ }^{185}$ Following phosphorylation and activation by PDK-1, the activated AKT can then phosphorylate its downstream substrates, including Bcl-2- associated agonist of cell death (Bad), caspase 9, glycogen synthase kinase-3 (GSK-3), mammalian forkhead transcription factors of the O class (FoxOs), mTOR, NFkB and p21, which have an impact on cell cycle, growth, proliferation and glycometabolism. ${ }^{184}$ Mutations and the consequent inappropriate activation of the PI3K/AKT pathway have been observed in many cancer types, contributing to genomic instability, metabolic reprogramming, uncontrolled cell growth and proliferation as well as multidrug resistance. ${ }^{186-}$ ${ }^{188}$ In breast cancer, resistance to endocrine therapy, HER2targeted therapy and cytotoxic chemotherapy has been reported. ${ }^{189,190}$ The downregulation of PI3K/AKT signalling may therefore offer benefits in breast cancer management.

M. indica pulp extract has demonstrated inhibitory effect on the PI3K/AKT pathway in both BT-474 cells and mice bearing BT-474 xenografts. ${ }^{24}$ In BT-474 cells, $M$. indica pulp extract (2.5-10 mg GAE/L) lowered the messenger ribonucleic acid (mRNA) levels of PI3K, AKT, hypoxia-inducible factor-1 alpha (HIF-1 $\alpha$ ) and vascular endothelial growth factor (VEGF) as well as the protein levels of phosphorylated PI3K (pPI3K), AKT, phosphorylated AKT (pAKT), NFKBp65 and VEGF. ${ }^{24}$ In BT-474 xenografts, $M$. indica pulp extract ( $0.8 \mathrm{mg} \mathrm{GAE} /$ day; 35 days) downregulated the protein levels of pPI3K, pAKT, NFKB-p65, mTOR, phosphorylated mTOR (pmTOR), HIF-1 $\alpha$ and VEGF. ${ }^{24}$

The observed anti-proliferative activities of $M$. indica polyphenols (eg, pyrogallol) in breast cancer cells have also been linked to the downregulation of PI3K/AKT pathway. ${ }^{56}$ Nemec et al ${ }^{56}$ analysed the mRNA levels of various PI3K/AKT pathway components in MCF10DCIS cells treated with $M$. indica polyphenols or pyrogallol (10 $\mathrm{mg} / \mathrm{L}$ ). Both $M$. indica polyphenols and pyrogallol lowered the mRNA levels of PI3K, mTOR and HIF- $1 \alpha^{56}$ However, while $M$. indica polyphenols increased the mRNA level of insulin-like growth factor-1 receptor (IGF-1R) and induced no significant change in the mRNA level of AKT, pyrogallol lowered the mRNA levels of both IGF-1R and AKT. ${ }^{56}$ As measuring changes in the 
mRNA levels of pathway components provided limited indication on their respective protein activities, the authors also conducted protein expression analysis. ${ }^{56}$ A reduction in the total protein levels of IGF-1R, insulin receptor (IR), AKT, mTOR and P70 S6 kinase (p70S6K; a kinase regulated by $\mathrm{mTOR}$ ) as well as the phosphorylated protein levels of IR, AKT and p70S6K were observed in MCF10DCIS cells following $M$. indica polyphenol treatment. ${ }^{56}$ On the other hand, pyrogallol reduced the total protein levels of IGF-1R, IR, insulin receptor substrate-1 (IRS-1), AKT, mTOR and p70S6K as well as the phosphorylated protein levels of IGF-1R, AKT and p70S6K. ${ }^{56}$ The same research group similarly reported a suppression of the PI3K/AKT pathway by M. indica polyphenols (0.8 mg GAE/day; 4 weeks) and pyrogallol (0.2 $\mathrm{mg} /$ day; 4 weeks) in mice bearing MCF10DCIS xenografts, based on findings from mRNA and protein expression analyses. ${ }^{57}$

A study by Hua et $\mathrm{al}^{94}$ linked the growth-inhibitory effect of 5GG on MCF-7 cells to a suppression of the PI3K/AKT pathway. In the study, it was observed that while $5 \mathrm{GG}(10-40 \mu \mathrm{M})$ had insignificant impact on total AKT protein level, it dose- and time-dependently reduced the phosphorylation of AKT at serine 473 and directly inhibited the activity of AKT. Moreover, 5GG $(20 \mu \mathrm{M})$ also inhibited epidermal growth factor- and/or estradiolinduced phosphorylation of RTKs upstream of the PI3K/ AKT pathway and downregulated the protein levels of several RTKs (EGFR, ErbB2 (or HER2) and ErbB3). ${ }^{94}$ In particular, 5GG-induced ErbB2 depletion was blocked by pre-treatment with chloroquine (CQ; a lysosomal inhibitor) but not carbobenzoxy-L-leucyl-L-leucyl-L-leucinal (MG132; a proteasome inhibitor), suggesting 5GG was likely to deplete ErbB2 by promoting its lysosomal degradation. ${ }^{94}$ Overall, 5GG can suppress PI3K/AKT signalling by inhibiting AKT and RTK phosphorylation as well as depleting RTKs. ${ }^{94}$

According to Rivera Rivera et al, ${ }^{150}$ quercetin (1-15 $\mu \mathrm{M})$ also exhibits inhibitory activity against the PI3KAKT pathway, as it is capable of inhibiting the phosphorylation of AKT at serine 473 and the phosphorylation of the downstream effectors of mTOR [p70S6K and eukaryotic translation initiation factor 4E-binding protein 1 (4EBP1)] in MDA-MB-231 cells. Figure 3 summarises changes in the mRNA, total protein and total phosphorylated protein levels of various PI3K/AKT pathway components induced by $M$. indica extracts and phytochemicals.

\section{Induction of MicroRNA-I26 (miR-I26) Expression}

MicroRNAs (miRNAs) are short non-coding RNAs implicated in the post-transcriptional regulation of eukaryotic gene expression. ${ }^{191}$ miRNAs bind to the 3 '-untranslated regions of their target mRNAs and, depending on the degree of miRNA-mRNA complementarity, can either result in mRNA degradation or translation inhibition. ${ }^{192}$ miRNAs are involved in various cellular processes such as cell development, differentiation, proliferation and apoptosis. ${ }^{192,193} \mathrm{~A}$ reduction in miR-126 expression has frequently been observed in breast cancer, and various studies have reported that a restoration of miR-126 expression can suppress breast cancer cell growth, metastasis and invasion; suggesting miR126 functions as a tumor suppressor in breast cancer. ${ }^{194,195}$ Therefore, the induction of miR-126 expression can be beneficial in treating breast cancer.

A study showed that $M$. indica pulp extract can induce miR-126 expression in BT-474 cells (2.5-10.0 mg GAE/L) and BT-474 xenografts in mice $(0.8 \mathrm{mg}$ GAE/day; 35 days). ${ }^{24}$ In the same study, the miRNA expression profile screening of extract-treated xenografts further revealed significant changes in the expression of several miRNAs that have a major role in the regulation of tumor cell growth and proliferation. These changes are potentially linked to the observed anti-proliferative effect of $M$. indica pulp extract. ${ }^{24}$

\section{Inhibition of Aromatase Enzymatic Activity and Expression}

Approximately $70 \%$ of all breast cancer cases are ER-positive, where ER activation by estrogen plays a key role in the stimulation of breast cancer growth and progression. ${ }^{196}$ The use of endocrine therapy, either selective estrogen-receptor modulators (SERMs) or aromatase inhibitors (AIs), as an adjuvant treatment has demonstrated improvement in the disease-free survival of ER-positive breast cancer patients. ${ }^{197}$ However, the risk of side effects associated with long-term AI use has triggered research into the discovery of a natural product-based new generation of AIs. ${ }^{51}$

Aromatase is a member of the cytochrome P450 superfamily of enzymes that catalyses the conversion of testosterone to estrogen in the final step of estrogen biosynthesis. ${ }^{198}$ Aromatase expression is tissue-specific and dependent upon 10 alternative untranslated exons I. ${ }^{199}$ Aromatase expression in normal breast adipose tissues is maintained at a low level, driven primarily by promoter I.4 and minimally by promoters 


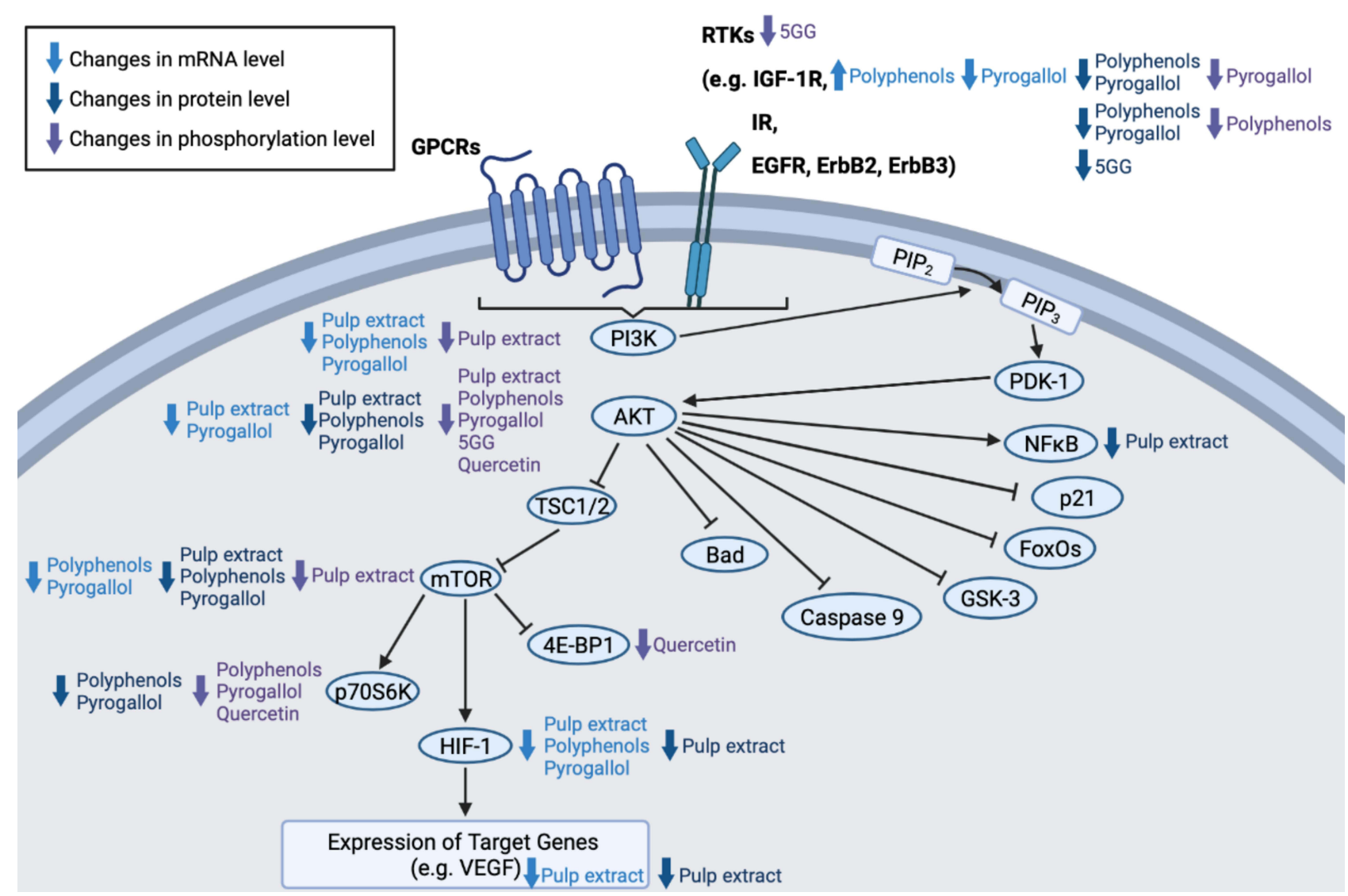

Figure 3 Suppression of PI3K/AKT/mTOR pathway by $M$. indica extracts and phytochemicals via reduction of pathway components' mRNA, total protein and phosphorylated protein levels.

Abbreviations: AKT, protein kinase B; Bad, Bcl-2-associated agonist of cell death; EGFR, epidermal growth factor receptor; ErbB2, Erb-B2 receptor tyrosine kinase 2; ErbB3, Erb-B2 receptor tyrosine kinase 3; FoxOs, mammalian forkhead transcription factors of the O class; GPCRs, G-protein-coupled receptors; GSK-3, glycogen synthase kinase-3; HIF-I, hypoxia-inducible factor-I; IGF-IR, ilnsulin-like growth factor-I receptor; IR, Insulin receptor; mTOR, mammalian target of rapamycin; NFאB, nuclear factor kappa B; PDK-I, phosphoinositide-dependent kinase-I; $\mathrm{PIP}_{2}$, phosphatidylinositol 4, 5-bisphosphate; $\mathrm{PIP}_{3}$, phosphatidylinositol 3, 4, 4-triphosphate; PI3K, phosphoinositide 3kinase; P70S6K, P70 S6 kinase; RTKs, receptor tyrosine kinases; TSCI/2, tuberous sclerosis proteins I and 2; 4E-BPI, eukaryotic translation initiation factor 4E-binding protein I.

I.3 and PII. ${ }^{200}$ In estrogen-dependent breast cancer, however, elevated aromatase expression has frequently been observed to be driven by mainly promoters I.3, I.4, I.7 and PII. ${ }^{200,201}$

In a study, ethanolic $M$. indica peel extract was reported to dose-dependently lower the activity of human placental aromatase, with $\mathrm{IC}_{50}$ at $86.09 \mu \mathrm{g} / \mathrm{mL}^{51}$ The same study also reported that ethanolic $M$. indica peel extract (33 or $66 \mu \mathrm{g}$ / $\mathrm{mL}$ ) can significantly reduce aromatase mRNA level in MCF-7 cells. The extract at $33 \mu \mathrm{g} / \mathrm{mL}$ caused a significant reduction in I.3-containing mRNA level (78\%), a significant increase in I.6-containing mRNA level (1478\%), a non-significant increase in I.7- and I.f-containing mRNA levels (294\% and 212\%) and non-significant change in PII-containing mRNA level. ${ }^{51}$ The extract at $66 \mu \mathrm{g} / \mathrm{mL}$, on the other hand, caused a significant reduction in I.3-, I.7- and PIIcontaining mRNA levels $(94 \%, 89.7 \%$ and $82 \%)$, a significant increase in I.6-containing mRNA level (500\%) and a non-significant increase in I.f-containing mRNA level $(100 \%){ }^{51}$ These observations collectively suggest the potential of $M$. indica peel extract to act as a tissue-specific AI in ER-positive breast cancer. ${ }^{51}$

\section{Modulation of Intracellular Calcium Signalling}

The calcium $\left(\mathrm{Ca}^{2+}\right)$ signalling is implicated in multiple cellular processes such as autophagy, ${ }^{202}$ cell cycle, ${ }^{203}$ death, ${ }^{204}$ differentiation, ${ }^{205}$ division, ${ }^{206}$ invasion, ${ }^{207}$ metabolism, ${ }^{208}$ migration ${ }^{209}$ and transcription. ${ }^{210}$ The key to $\mathrm{Ca}^{2+}$ signalling is the differential distribution of $\mathrm{Ca}^{2+}$ concentrations across cell membranes, between extracellular space and cytoplasm as well as between cytoplasm and organelles such as ER and Golgi apparatus. ${ }^{211}$ Movement of $\mathrm{Ca}^{2+}$ ions down their electrochemical gradients produces $\mathrm{Ca}^{2+}$ signals. ${ }^{211}$ This can occur with electrical, hormonal or mechanical stimulation 
of cells, which can activate either GPCRs that typically trigger $\mathrm{Ca}^{2+}$ mobilisation from intracellular stores via lipid signal transduction; or ion channels that allow $\mathrm{Ca}^{2+}$ movement through central pore opening. ${ }^{212}$ The resulting increase in cytoplasmic $\mathrm{Ca}^{2+}$ concentration and $\mathrm{Ca}^{2+}$-binding of calcium-binding proteins (CBPs) ultimately leads to the initiation of cellular functions. ${ }^{213}$

The dysregulated expression of a number of $\mathrm{Ca}^{2+}$ channels and pumps has been reported in either breast cancer tissues or breast cancer cell lines, whereby they result in the remodelling of $\mathrm{Ca}^{2+}$ signalling. ${ }^{214}$ There have been evidences linking altered $\mathrm{Ca}^{2+}$ signalling to various malignant functions such as cell proliferation, migration, invasion and metastasis in breast cancer. ${ }^{211} \mathrm{Ca}^{2+}$ channels and pumps, therefore, may be potentially useful anti-cancer targets in breast cancer treatment.

Taing et $\mathrm{al}^{53}$ evaluated the effects of methanolic $M$. indica peel and pulp extracts $\left(30\right.$ or $60 \mu \mathrm{g} / \mathrm{mL}$ ) on $\mathrm{Ca}^{2+}$ signalling in MCF-7 cells. In untreated MCF-7 cells, adenosine triphosphate (ATP) stimulation resulted in a rapid increase in intracellular $\mathrm{Ca}^{2+}$ concentration $\left[\mathrm{Ca}^{2+}\right]_{\mathrm{I}}$, which was followed by a recovery to basal $\left[\mathrm{Ca}^{2+}\right]_{\mathrm{I}} .{ }^{53}$ In extracttreated MCF-7 cells, however, significant reduction in peak relative $\left[\mathrm{Ca}^{2+}\right]_{\mathrm{I}}$ and delay in $\left[\mathrm{Ca}^{2+}\right]_{\mathrm{I}}$ recovery were noted. ${ }^{53}$ Further studies are thus required to ascertain the target(s) upon which the extracts are acting to cause the observed changes in $\mathrm{Ca}^{2+}$ signalling, and to assess if the extracts have an influence on any $\mathrm{Ca}^{2+}$-dependent signalling pathways. ${ }^{53}$

Studies by Chien et $\mathrm{al}^{149}$ and Chou et al) ${ }^{148}$ also showed that quercetin $(250$ or $150 \mu \mathrm{M})$ can elevate cytosolic $\mathrm{Ca}^{2+}$ level in MDA-MB-231 and MCF-7 cells, respectively. These findings suggest that further studies would be required to evaluate the influence of quercetin on $\mathrm{Ca}^{2+}$-dependent signalling pathways and the link between this influence and quercetin's anti-breast cancer activity. ${ }^{148,149}$

\section{Inhibition of Nuclear Factor Kappa B Signalling Pathway}

Nuclear factor kappa B (NFkB), a pro-inflammatory transcription factor, is expressed in virtually all cell types. ${ }^{215}$ The NFKB family of transcription factors comprises five

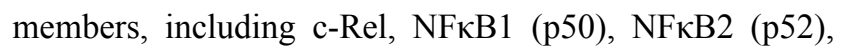
RelA (p65) and RelB. ${ }^{216}$ Different combinations of these members make up homodimeric or heterodimeric $\mathrm{NF \kappa B}$, with the most common combination being a p65/p50 heterodimer. ${ }^{216,217} \mathrm{NF \kappa B}$ dimers are usually complexed with the inhibitor of $\mathrm{NF \kappa B}$ (I $\kappa \mathrm{B})$, which retains $\mathrm{NF \kappa B}$ dimers in the cytoplasm and thereby prevents $\mathrm{NF \kappa B}$ dimers from binding DNA. ${ }^{218} \mathrm{NF \kappa B}$ activation can occur via two major signalling pathways (ie, classical/canonical and alternative/non-canonical pathways). ${ }^{219}$ The eventual phosphorylation and ubiquitination of IKB within their signal responsive domain (SRD) results in signal responsive degradation, thereby releasing $\mathrm{NF} \kappa \mathrm{B}$ from $\mathrm{I} \kappa \mathrm{B}$ and enabling NFKB to bind to $\kappa \mathrm{B}$ sites within the promoters of their target genes. ${ }^{218}$

Alterations of NFKB pathway are often observed in solid and hematopoietic malignancies. ${ }^{220}$ For instance, abnormal, constitutive NFKB activation is frequently seen in breast cancer, and it is believed to contribute to breast cancer development and progression by promoting angiogenesis, cell survival, proliferation, metastasis as well as resistance to chemotherapy, endocrine therapy and radiotherapy. ${ }^{216,221-225} \mathrm{NF \kappa B}$ pathway has thus been considered as a potential target for breast cancer therapy.

A study by García-Rivera et $\mathrm{al}^{34}$ reported that Vimang $(200 \mu \mathrm{g} / \mathrm{mL})$, mangiferin $(100 \mu \mathrm{g} / \mathrm{mL})$ and gallic acid $(10$ $\mu \mathrm{g} / \mathrm{mL}$ ) can inhibit the classical NFKB activation pathway in MDA-MB-231 cells by inhibiting the phosphorylation of IKB kinase alpha (IKK $\alpha$; at serines 176 and 180) and I $\kappa$ B kinase beta (IKK $\beta$; at serines 177 and 181), which can consequently result in reduced I $\mathrm{B}$ degradation, p65 nuclear translocation and NFKB DNA binding. The optimal activation of $\mathrm{NF \kappa B}$ also involves the phosphorylation of its functional domains by various protein kinases. 226,227 In the same study, Vimang and gallic acid were observed to inhibit the MEK/ERK/p90RSK/MSK signalling cascade while mangiferin appeared to have insignificant effect. ${ }^{34}$ Since gallic acid can inhibit both classical and parallel $\mathrm{NF \kappa B}$ activation pathways while mangiferin can inhibit only the classical NFKB activation pathway, gallic acid is likely to be a more potent NFKB inhibitor. ${ }^{34}$ As a consequence of $\mathrm{NFKB}$ pathway inhibition, there was also a significant reduction in the expression of $\mathrm{NF \kappa B}$ target genes, including interleukin (IL)-6, IL-8, VEGF, Bcl-2, XIAP, COX-2 and C-X-C chemokine receptor type 4 (CXCR4), in MDA-MB-231 cells treated with Vimang, mangiferin or gallic acid. ${ }^{34}$

Consistent with the findings of García-Rivera et al, ${ }^{34} \mathrm{a}$ previous study conducted by Sarkar et $\mathrm{al}^{228}$ also reported on the inhibitory effect of mangiferin on NFkB activation. In the study, mangiferin $(0.5-10 \mu \mathrm{g} / \mathrm{mL})$ suppressed TNFstimulated activation of NFKB in MCF-7 cells. Figure 4 


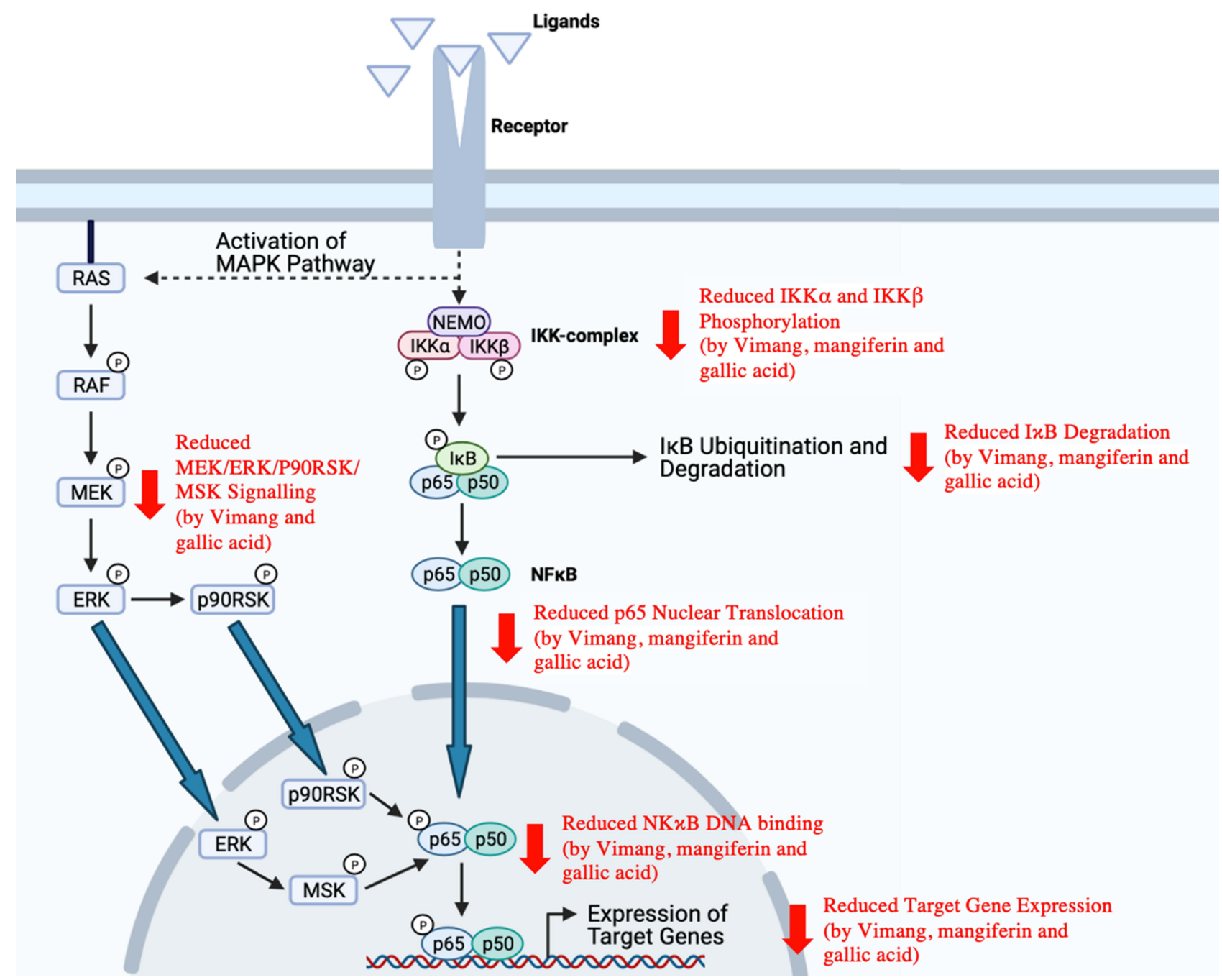

Figure 4 Inhibition of classical and parallel NFKB activation pathways by $M$. indica extracts and phytochemicals.

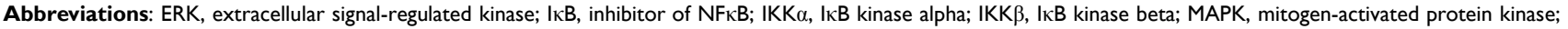
MSK, mitogen- and stress-activated kinase; NEMO, Nuclear factor kappa B essential modulator; p90RSK, 90 kDa ribosomal s6 kinase.

illustrates various processes along the NFkB signalling pathway that have been shown to be suppressed by $M$. indica extracts and phytochemicals.

\section{Inactivation of $\beta$-Catenin Pathway}

Wnts, a family of 19 secreted glycoproteins, are chief regulators of $\beta$-catenin activity. ${ }^{229}$ In the absence of Wnt signal, $\beta$-catenin is constantly maintained at a low cytoplasmic level via the action of a destruction complex consisting of Axin, adenomatous polyposis coli protein (APC), casein kinase 1 (CK1) and GSK-3, where $\beta$-catenin phosphorylation by CK1 and GSK-3 eventually leads to its ubiquitination and proteasomal degradation. ${ }^{230}$ Activation of the Wnt/ $\beta$-catenin pathway is initiated with the binding of Wnt to the Frizzled (Fz) receptor and its co-receptor [ie, low-density lipoprotein receptor-related protein 5/6 (LRP5/6)]. ${ }^{231}$ The subsequent recruitment of Dishevelled (Dvl) protein, the phosphorylation and activation of LRP5/6 as well as the recruitment of destruction complex eventually ceases $\beta$-catenin degradation, thereby leading to $\beta$-catenin accumulation and nuclear translocation. ${ }^{231}$ The expressions of Wnt target genes are usually repressed by $\mathrm{T}$ cell-factor/transducin-like enhancer of split (TCF/TLE) proteins and histone deacetylase (HDAC). ${ }^{232}$ As $\beta$-catenin binds to lymphoid enhancer factor (LEF)/TCF family of transcription factors to form a binding complex, it can act as a co-activator for LEF/TCF proteins to activate the expression of Wnt target genes involved in various biological processes. ${ }^{232,233}$

Dysregulation of the Wnt/ $\beta$-catenin signalling pathway has been associated with different diseases, including 
human cancers. ${ }^{234}$ Various studies have demonstrated that aberrant activation of the $\mathrm{Wnt} / \beta$-catenin signalling pathway can promote angiogenesis, cell proliferation, migration, invasion and chemoresistance, thereby contributing to cancer initiation and progression. ${ }^{235-237}$ For example, constitutively active Wnt/ $\beta$-catenin pathway has been linked to metastasis in breast cancer. ${ }^{234,238}$

Mangiferin (12.5-50 $\mu \mathrm{M})$ has been reported to downregulate matrix metalloproteinases (MMP)-7 and -9 and reverse epithelial-mesenchymal transition (EMT) in MDAMB-231 and BT-549 cells, as evidenced by the observations of morphological changes (from fibroblast-like to cobblestone-like), significantly increased levels of epithelial marker (E-cadherin) and significantly decreased levels of mesenchymal markers (vimentin, snail and slug) following treatment. $^{66}$ Similar in vivo effects have been observed in MDA-MB-231 xenografts of mice subjected to mangiferin treatment $(100 \mathrm{mg} / \mathrm{kg} /$ day; 5 weeks $){ }^{66}$ The same study also suggested that mangiferin can inhibit the $\beta$-catenin pathway by lowering the protein levels of inactive phospho-GSK3 $\beta$ $(p-G S K 3 \beta)$ and active $\beta$-catenin both in vitro and in vivo. Furthermore, while $\beta$-catenin overexpression reversed the anti-proliferative, anti-migratory and anti-invasive effects of mangiferin in MDA-MB-231 and BT-549 cells, $\beta$-catenin silencing downregulated MMP-7, MMP-9 and snail, indicating that the inactivation of $\beta$-catenin pathway may contribute to the anti-cancer effects of mangiferin by modulating MMP7, MMP-9 and EMT. ${ }^{66}$ The overall study findings by Li et al ${ }^{66}$ on mangiferin-mediated inactivation of $\beta$-catenin pathway are as summarised in Figure 5.

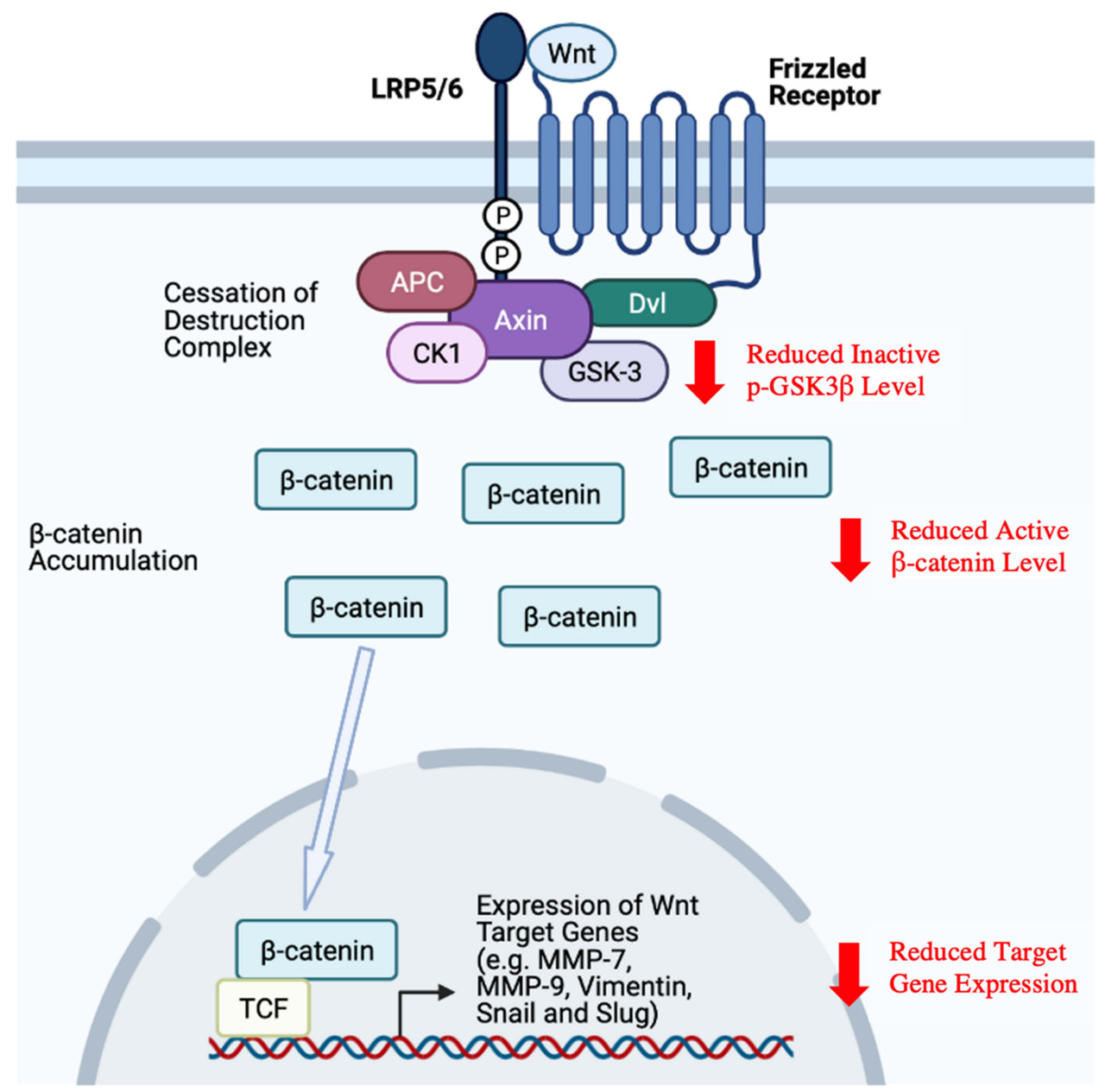

Figure 5 Inactivation of $\beta$-catenin pathway by mangiferin.

Abbreviations: APC, adenomatous polyposis coli protein; CKI, casein kinase I; Dvl, Dishevelled; GSK-3, glycogen synthase kinase-3; LRP5/6, low-density lipoprotein receptor-related protein 5/6; MMP-7/9, matrix metalloproteinase-7/9; p-GSK3 $\beta$, phospho-GSK3 $\beta$; TCF, T cell-factor. 


\section{Inhibition of 3-Hydroxy-3-Methyl- Glutaryl-Coenzyme A Reductase, Proteasome and Plasmin Enzymatic Activities}

3-Hydroxy-3-methyl-glutaryl-coenzyme A (HMG-CoA) reductase is an enzyme that catalyses the rate-limiting step (ie, conversion of HMG-CoA to mevalonate) of cholesterol biosynthesis. ${ }^{239}$ Low-density lipoprotein (LDL) cholesterol signalling has been associated with the promotion of cell proliferation, migration and invasion in breast cancer, suggesting the control of cholesterol level may be beneficial.240,241 The statins, a class of cholesterol-lowering drugs, exert their hypocholesterolemic effects by blocking the activity of HMG-CoA reductase. ${ }^{242}$ There have been evidences suggesting that the inhibition of HMG-CoA reductase by statins can impair breast cancer cell proliferation, making statins potentially useful in breast cancer treatment. ${ }^{243}$ Cuccioloni et al ${ }^{68}$ found that mangiferin at low $\mu \mathrm{M}$ concentrations (ie, inhibition constant of $3 \pm 0.2 \mu \mathrm{M}$ ) can similarly reduce the activity of microsomal HMG-CoA reductase. As expected, this translated to a significant dose-dependent reduction in the cytoplasmic cholesterol levels of MCF-7 and MCF-10A cells following exposure to mangiferin. ${ }^{68}$ These effects of mangiferin on cholesterol homeostasis can, thus, potentially explain its observed anti-cancer activity in breast cancer cells. ${ }^{68}$

The ubiquitin-proteasome pathway (UPP) is the major pathway responsible for degrading more than $80-90 \%$ of the intracellular proteins in mammalian cells. ${ }^{244}$ Importantly, UPP is also known to play an important role in the regulation of cellular processes involved in both tumor cell growth and survival. ${ }^{245}$ Studies with proteasome inhibitors have demonstrated anti-proliferative and pro-apoptotic activities in tumor cells, thereby suggesting the potential usefulness of proteasome inhibitors as anti-cancer agents. ${ }^{246-248}$ When Cuccioloni et al ${ }^{68}$ evaluated the effect of mangiferin (1-20 $\mu \mathrm{M})$ on various catalytic activities of isolated 20 S proteasome, a significant dose-dependent reduction was observed for chymotrypsin-like (ChT-L), trypsin-like (T-L), peptidylglutamyl peptide hydrolase (PGPH) and branched-chain amino acid preferring (BrAAP) activities, with T-L activity being the most sensitive to inhibition by $20 \mu \mathrm{M}$ mangiferin. When proteasome activities in the lysates of mangiferintreated MCF-7 and MCF-10A cells were measured, significantly reduced ChT-L, T-L, PGPH and BrAAP activities were similarly observed. ${ }^{68}$
Plasminogen, a single-chain glycoprotein, is usually found in the blood circulation in its inactive form. ${ }^{249}$ Upon association with cellular receptors, the resulting conformational changes induced in plasminogen promote the catalysis of its activation to plasmin by either urokinase plasminogen activator (uPA) or tissue plasminogen activator (tPA) ${ }^{250}$ Plasmin is a serine protease that has a primary role in fibrinolysis. ${ }^{251}$ However, the ability of plasmin to catalyse the degradation of ECM proteins and cell-cell adhesion proteins has also associated plasmin with cellular migration in both physiological (eg, embryonic angiogenesis and wound healing) and pathological (eg, tumor growth and metastasis) conditions. ${ }^{252-254}$ This provides a rationale for plasmin inhibition in cancer management. In a study, Cuccioloni et $\mathrm{al}^{68}$ observed that mangiferin $(0-200 \mu \mathrm{M})$ exhibited a moderate inhibitory potency against isolated plasmin. As expected, mangiferin was also reported to cause a significant dose-dependent reduction in the cleavage of E-cadherin by plasmin in both MCF-7 and MCF$10 \mathrm{~A}$ cells. ${ }^{68}$ The plasmin inhibitory effect of mangiferin can thus, at least partly, help to explain its observed anti-migratory activity in breast cancer cells. ${ }^{68}$

\section{Inhibition of Racl/WAVE2 Signalling Pathway}

Rho-family of small GTPases play an important role in the regulation of a range of cellular processes, including cell apoptosis, motility, mitosis and proliferation. ${ }^{255}$ Cell division control protein 42 homolog $(\mathrm{Cdc} 42)$ and Ras-related C3 botulinum toxin substrate 1 ( $\operatorname{Rac} 1)$, two members of the Rho-family of small GTPases, have specifically been associated with the activation of actin polymerisation and thereby, the modulation of cellular cytoskeletal reorganisation. ${ }^{256}$ Wiskott-Aldrich Syndrome protein (WASP) and WASP-family verprolin-homologous protein (WAVE), the respective downstream effectors of Cdc42 and Rac1, are capable of activating the actin-related protein $2 / 3$ (Arp2/3) complex that is the major cellular machinery for actin nucleation. ${ }^{257}$ Activation of the Arp $2 / 3$ complex eventually results in the remodelling of actin filament networks as well as the formation of membrane protrusions and ruffles required for cellular motility in tumor cells. ${ }^{256,258}$ Despite the existence of other members of the WAVE family of proteins, it has been shown that WAVE2 tends to be the most important in mediating breast cancer cell motility. ${ }^{259}$ As such, inhibiting actin 
polymerisation via the suppression of Rac1/WAVE2 signalling pathway may be effective in preventing metastasis.

It was reported by Deng et $\mathrm{al}^{67}$ that mangiferin (2.5-10 $\mu \mathrm{M})$ can induce a significant dose-dependent reduction in the protein levels of Rac1/Cdc42, phospho-Rac1/Cdc42 (pRac1/Cdc42), WAVE2, Arp2 and Arp3 in MDA-MB231 cells, which is indicative of a suppression of the Rac1-WAVE2 signalling pathway (Figure 6). The authors linked this suppressive effect of mangiferin to its observed anti-migratory and anti-invasive activities in breast cancer cells.

\section{Modulation of Estrogen Receptor Activity}

ERs belong to the steroid hormone superfamily of nuclear receptors. ${ }^{260}$ Upon activation by estrogen binding, the subsequent ER-mediated signalling can occur in either a genomic or non-genomic manner. ${ }^{261}$ Direct genomic signalling, the classical estrogen signalling mechanism, involves conformational change and dimerization of ER, nuclear translocation of ER complex and their subsequent interaction with chromatin in estrogen response elements (EREs) to directly regulate gene expression. ${ }^{262}$ In contrast, non-genomic signalling is mediated by membrane-bound ER and can indirectly regulate gene expression via the activation of various intracellular signalling cascades. ${ }^{263}$
There are two structurally and functionally distinct ER subtypes (ie, ER $\alpha$ and ER $\beta$ ), both of which are expressed in normal breast tissues. ${ }^{264}$ In breast cancer, while ER $\alpha$ expression is frequently found to be upregulated and is clearly associated with both prognosis and endocrine treatment response, ER $\beta$ expression is usually observed to be downregulated and has no clear association with any clinical parameters. $^{264}$ ER $\alpha$ and ER $\beta$ have been known to play a different role in tumorigenesis, where $\mathrm{ER} \alpha$ is proliferative while ER $\beta$ appears to be anti-proliferative. ${ }^{265}$ However, it has been reported that ER $\beta$ can oppose the proliferative activity of $E R \alpha$ in co-expression, possibly via the formation of $\mathrm{ER} \alpha / \beta$ heterodimers. ${ }^{266}$ Moreover, $\mathrm{ER} \alpha / \beta$ heterodimerselective ligands have demonstrated growth-inhibitory effect on tumor cells and thus can potentially be useful in the treatment of ER $\alpha$ - and ER $\beta$-positive breast cancer. ${ }^{266}$

To elucidate the mechanisms underlying the observed anti-breast cancer activities of $M$. indica phytochemicals, a study examined the effects of quercetin, mangiferin and norathyriol $(1-1000 \mu \mathrm{M})$ on the ERE transactivation activities of $E R \alpha$ and $\operatorname{ER} \beta$ in Cos-7 cells. ${ }^{75}$ While it was reported that all three $M$. indica phytochemicals are capable of activating $E R \alpha$, only norathyriol is capable of activating ER $\beta .^{75}$ Therefore, further studies are required to investigate the link of these differential ER-modulatory effects to the observed lack of anti-proliferative effect of

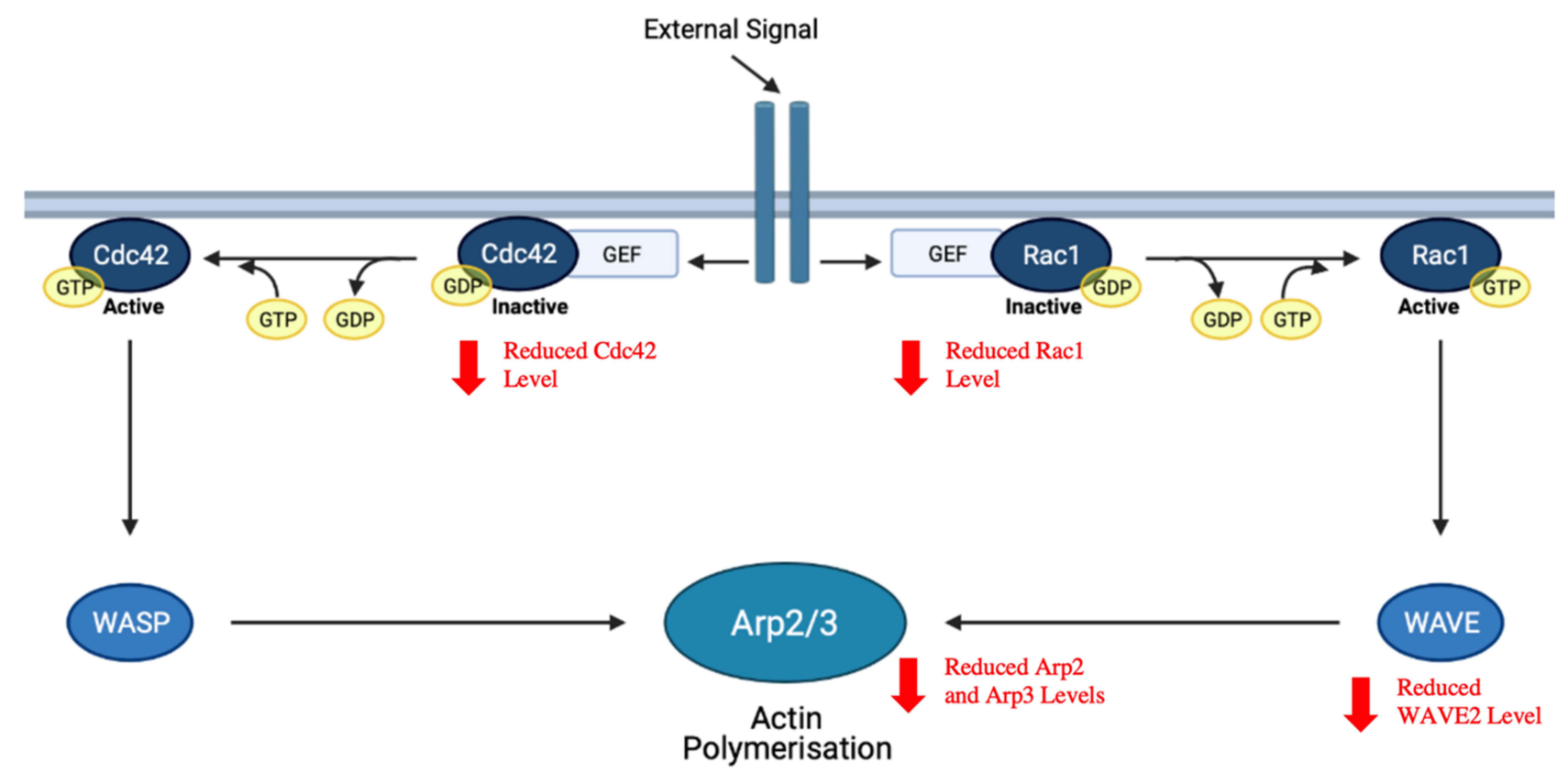

Figure 6 Inhibition of Racl/WAVE2 signalling pathway by mangiferin. Arp2/3, activating the actin-related protein 2/3; Cdc42, cell division control protein 42 homolog; GEF, guanine nucleotide exchange factor; Racl, Ras-related C3 botulinum toxin substrate I; WASP, Wiskott-Aldrich syndrome protein; WAVE, WASP-family verprolinhomologous protein. 
mangiferin as well as the observed anti-proliferative effects of quercetin and norathyriol on MCF-7 cells; and to evaluate the effects of these $M$. indica phytochemicals on $\mathrm{ER} \alpha / \beta$ heterodimer activity. ${ }^{75}$

$5 \mathrm{GG}$, another $M$. indica phytochemical, has also been reported to exert growth-inhibitory effect on MCF-7 by inhibiting ER $\alpha$ function. ${ }^{94}$ Specifically, the study revealed that $5 \mathrm{GG}(1-40 \mu \mathrm{M})$ can inhibit ER $\alpha$ activity by promoting $\mathrm{ER} \alpha$ degradation through the lysosomal pathway or blocking all known pathways of ER $\alpha$ activation - estrogen-mediated activation, growth factor-induced phosphorylation of the amino-terminal activation function-1 (AF-1) and cyclin D1-mediated activation. ${ }^{94}$

\section{Activation of AMP-Activated Protein Kinase Signalling Pathway}

AMP-activated protein kinase (AMPK) is a serine/threonine kinase complex consisting of a catalytic subunit (AMPK- $\alpha$ ) and two regulatory subunits (AMPK- $\beta$ and AMPK- $\gamma$ ) ${ }^{267}$ It is regarded as a sensor of intracellular adenosine nucleotide levels, where it is activated in response to cellular stresses that can reduce intracellular ATP level. ${ }^{268}$ AMPK activation involves the phosphorylation of its conserved threonine 172 residue by an upstream kinase such as $\mathrm{Ca}^{2+} /$ calmodulindependent protein kinase $\beta(\mathrm{CaMKK} \beta)$, liver kinase $\mathrm{B} 1$ (LKB1) and transforming growth factor $\beta$ activated kinase 1 (TAK1). ${ }^{269}$ More recent studies have further suggested AMPK's role as an oxidative stress sensor in addition to its traditional role as an energy sensor, where it can be activated in response to increased intracellular ROS/reactive nitrogen species (RNS) levels. ${ }^{270-272}$

AMPK has physiological roles in the regulation of cell growth, metabolism, polarity and autophagy, and AMPK activation has been recognised to exert beneficial effects in various pathological conditions. ${ }^{268}$ The downregulation of AMPK has been associated with poor outcomes in breast cancer patients. ${ }^{273}$ However, there have been reports that suggest AMPK activation can exert a growth-inhibitory effect on breast cancer cells, thus making AMPK signalling pathway a promising target in breast cancer treatment. ${ }^{274-276}$

A study proposed that the observed inhibitory effects of $M$. indica polyphenols ( $0.8 \mathrm{mg}$ GAE/day; 4 weeks) and pyrogallol (0.2 mg/day; 4 weeks) on MCF10DCIS xenograft tumor growth can be attributed at least partly to AMPK pathway activation and AKT/mTOR pathway suppression. ${ }^{57}$ In the study, mice of both treatment groups showed elevated levels of Sestrin2, phosphorylated AMPK and Beclin1 as well as reduced levels of mTOR and pmTOR. However, while elevated level of LKB1 was only seen in pyrogalloltreated mice, elevated levels of Unc-51-like kinase (ULK) and phosphorylated ULK were only seen in polyphenoltreated mice. ${ }^{57}$ Sestrin2, a highly conserved stress-inducible protein, is known to be capable of activating AMPK that can in turn inhibit mTOR. ${ }^{277}$ In addition, both ULK and Beclin1, which are involved in the induction of autophagic process, are also the downstream targets of AMPK. ${ }^{278}$ Subsequent in vitro assays performed on MCF10DCIS cells linked AMPK pathway activation induced by $M$. indica polyphenols and pyrogallol (1-20 mg/L) to their abilities to increase ROS generation. ${ }^{57}$ Moreover, it was reported that pyrogallol can also activate the AMPK pathway by binding directly to the allosteric site of AMPK or upregulating AMPK expression. ${ }^{57}$

On the other hand, quercetin's anti-cancer activity has been linked to an upregulation of AMPK signalling in another study, whereby quercetin $(15 \mu \mathrm{M})$ was observed to significantly increase AMPK phosphorylation (by twofold) in MDA-MB-231 cells. ${ }^{150}$ Figure 7 summarises the study observations suggesting an upregulation of the AMPK signalling pathway following treatment with $M$. indica extracts and their phytochemicals.

\section{Modulation of Cell Cycle Regulators}

Cell cycle is a process comprising four major phases (ie, G1-, S-, G2- and M-phases), during which the doubling of cellular components and their accurate segregation into two daughter cells occur. ${ }^{279}$ Transition through each phase of the cell cycle is under tight regulation by specific proteins. ${ }^{279}$ Cyclin-dependent kinases (CDKs), a family of serine/threonine protein kinases, are the key regulatory proteins that control cell cycle progression when complexed with their regulatory subunits (ie, cyclins). ${ }^{280}$ G1-to-S-phase transition involves the activation of CDK4, 6 activity by D-type cyclin binding. ${ }^{281}$ One target of cyclin D-CDK4, 6 activity is the retinoblastoma tumor suppressor protein $(\mathrm{Rb})$, which will dissociate from E2F transcription factors following phosphorylation to enable E2Finduced expression of cyclins E, A and thymidylate synthase, etc. $^{282,283}$ Continued phosphorylation and complete inactivation of $\mathrm{Rb}$ in the late G1-phase is achieved by the complexes formed from cyclins $\mathrm{E}$ and $\mathrm{A}$ as well as CDK1 and 2. ${ }^{284} \mathrm{On}$ the other hand, cyclinB-CDK1 activity is known to drive cellular events associated with mitosis, thereby facilitating G2-to-Mphase transition. ${ }^{285}$ The activity of cyclin-CDK complexes can be counteracted by two gene families of CDK inhibitors (CKIs), thereby resulting in cell cycle arrest. ${ }^{286}$ While INK4 gene family members (p16INK4a, p15INK4b, p18INK4c and 


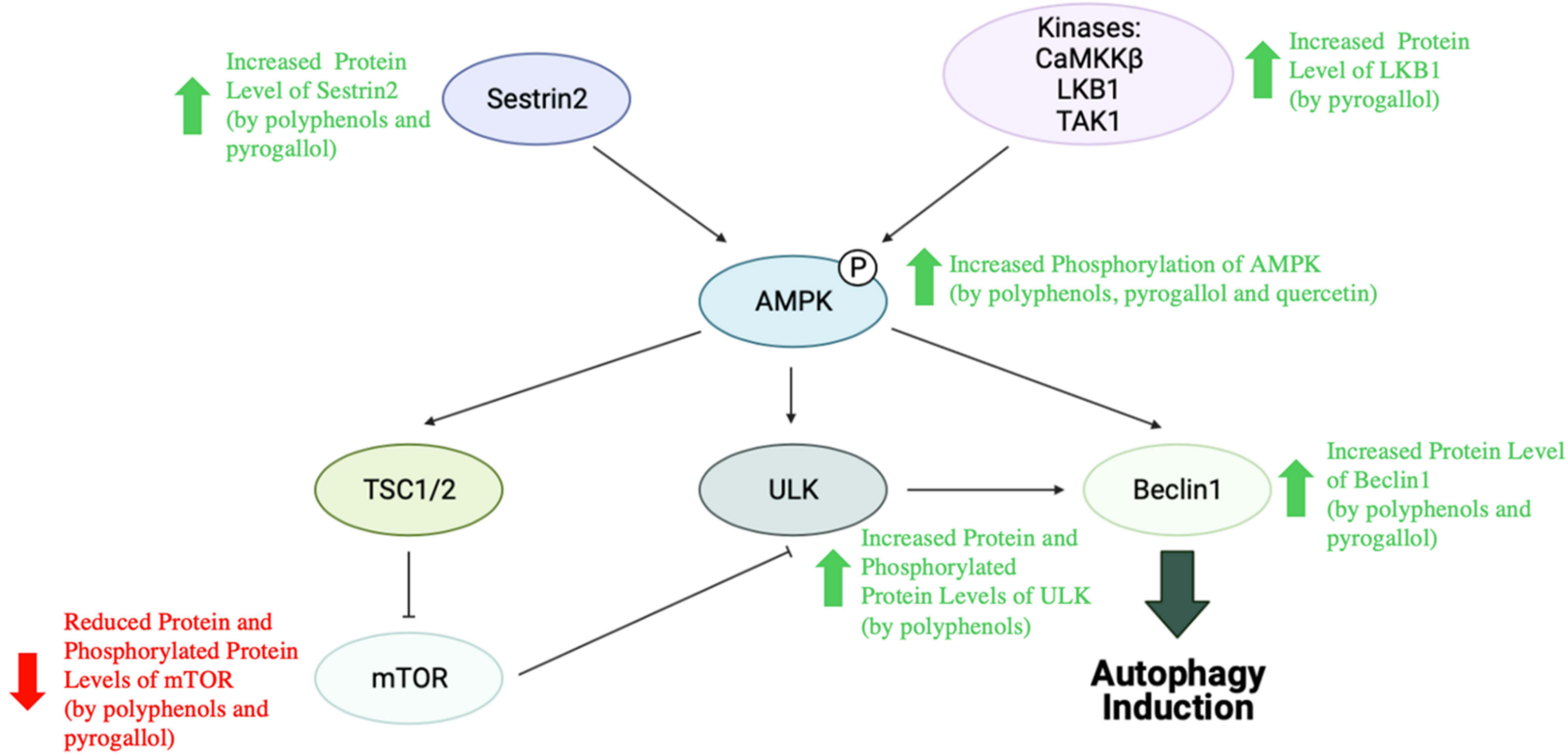

Figure 7 Activation of AMPK signalling pathway by M. indica extracts and phytochemicals.

Abbreviations: AMPK, AMP-activated protein kinase; CAMKK $\beta$, calcium/calmodulin-dependent protein kinase $\beta$; LKBI, liver kinase BI; mTOR, mammalian target of rapamycin; TAKI, transforming growth factor $\beta$ activated kinase I; TSCI/2, tuberous sclerosis proteins I and 2; ULK, Unc-5I-like kinase.

p19INK4d) are capable of inhibiting CDK4, 6 activity, Cip/ Kip gene family members (p21Cip1/Waf1/Sdi1, p27Kip1 and p57Kip2) can interfere with the activities of cyclins D-, E-, and A-CDK complexes. ${ }^{286}$

Deregulation of cell cycle, which confers cells with the ability to undergo cell division endlessly, is one of the hallmarks of cancer. ${ }^{287}$ In breast cancer, deregulation of cell cycle often results from an aberrant activation of CDKs and cyclins as well as an inactivation of tumor suppressors. ${ }^{288}$ As such, several CDK4/6 inhibitors (ie, abemaciclib, palbociclib and ribociclib) have been approved by FDA for the treatment of breast cancer, and a number of cell cycle inhibitors (eg, TTK protein kinase [TTK] and polo-like kinase 4 [PLK4] inhibitors) are currently under development. ${ }^{287}$

Chen et $\mathrm{al}^{95}$ reported the ability of $5 \mathrm{GG}(50 \mu \mathrm{M})$ to induce a G1-phase arrest in MCF-7 cells and proceeded to investigate the underlying mechanisms of this arrest. Overall study findings suggested that 5GG treatment can increase the protein level of $\mathrm{p} 27 \mathrm{Kip}$, which can in turn bind to and inhibit $\mathrm{CDK} 2$ and 4 kinase activities, resulting in a reduced $\mathrm{Rb}$ phosphorylation and thus preventing E2F-induced expression of S-phase genes. ${ }^{95}$ Moreover, it was also reported that 5 GG may block the association of p21Cip with cyclin D-CDK4 complexes, which would usually be required to increase the stability and activity of cyclin D-CDK4 complexes implicated in G1-to-S-phase transition. ${ }^{95}$
Gallic acid (2-12 $\mu \mathrm{g} / \mathrm{mL})$ has also been reported to induce S- and G2/M-phase arrest in MCF-7 cells, which is linked to its ability to dose-dependently lower the protein levels of cyclin A, cyclin B1, cdc2/CDK1 and CDK2. ${ }^{111}$ Additionally, gallic acid can also dose- and time-dependently downregulate S-phase kinase-associated protein 2 (Skp2) and prevent it from ubiquitinating p21Cip1 and p27Kip1, thereby preventing the proteasomal degradation of p21Cip1 and p27Kip1 and leading to cell cycle arrest.111 However, as the silencing of p27Kip1 but not p21Cip1 can significantly diminish gallic acid-induced increase in G2/M-phase ratio, p27Kip1 may play a more important role than $\mathrm{p} 21 \mathrm{Cip} 1$ in the observed cell cycle arrest induced by gallic acid. ${ }^{111}$

Quercetin can also induce cell cycle arrest in breast cancer cell lines. For instance, Chien et $\mathrm{al}^{149}$ observed a G2/M-phase arrest in MDA-MB-231 cells following quercetin treatment $(200 \mu \mathrm{M})$, and correlated this with a reduction in the protein levels of cyclin A, cyclin B and thymidylate synthase as well as an increase in the protein levels of p53 and p57. On the other hand, Chou et al ${ }^{148}$ reported that quercetin $(150 \mu \mathrm{M})$ can induce a S-phase arrest in MCF-7 cells by downregulating the protein levels of CDK2, cyclin A, cyclin E and thymidylate synthase as well as upregulating the protein levels of p53 and p57. 
Future Perspective: Fabrication of Smart Nanofiber Matrices for Breast Cancer Therapy

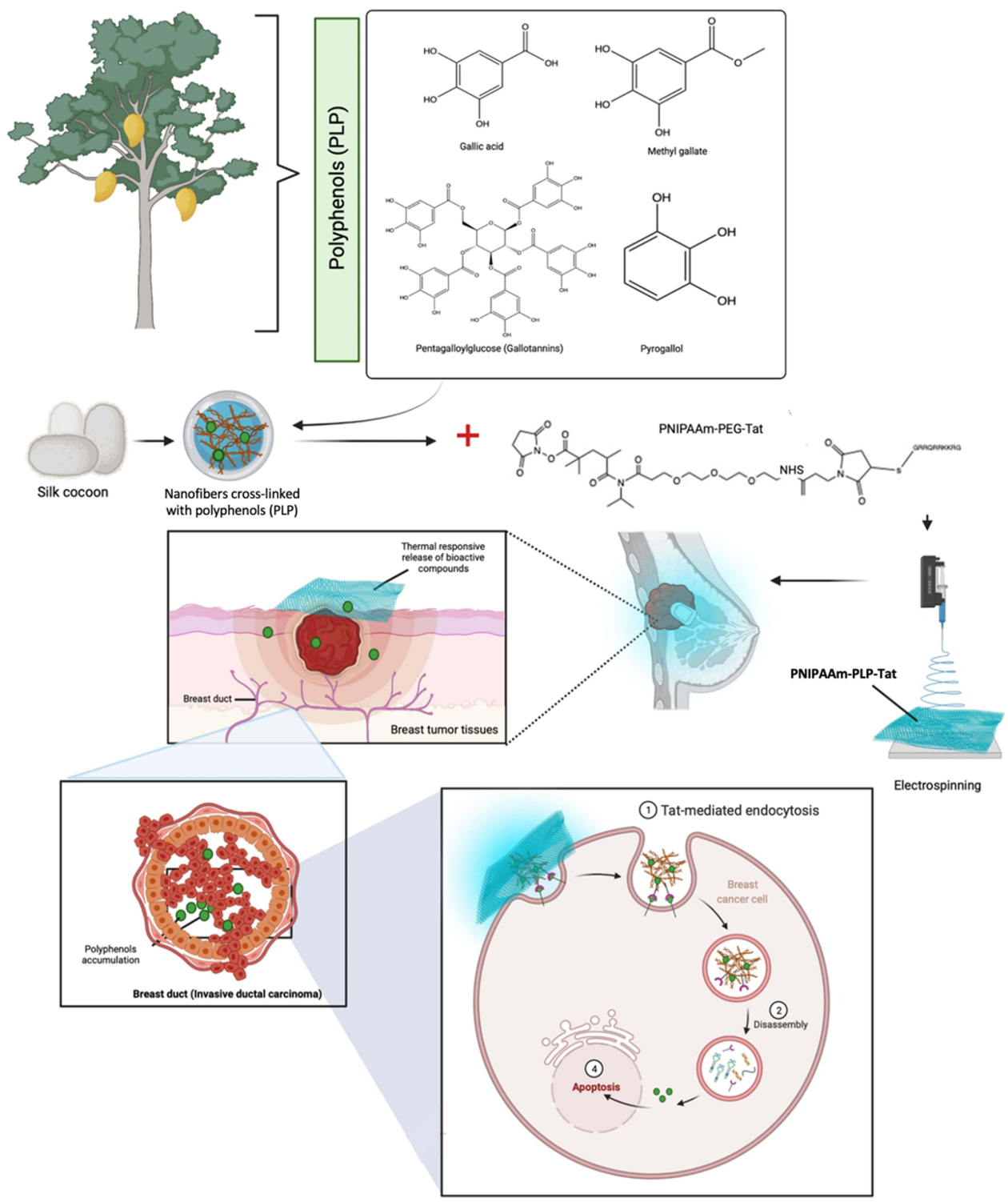

Figure 8 Fabrication of smart nanofiber matrices for breast cancer therapy. Polyphenolic compounds (PLP) from M. indica have been studied extensively as antiinflammatory and anti-cancer agents. In the proposed future study, M. indica PLP will be cross-linked to silk fibroin (cocoon) nanofibers before being conjugated with PNIPAAm-PEG-Tat to yield PNIPAAm-PLP-Tat, which can then be released in a thermal responsive burst at breast tumor tissues. The use of cell-penetrating peptide (Tat) permits targeted intracellular transport of PLP into breast cancer cells.

\section{Conclusion and Future Perspectives}

This review provides a comprehensive summary of the studies on the anti-cancer effects of extracts prepared from various parts of M. indica (ie, bark, kernel, leaves, peels and pulps) and its polyphenolic phytochemicals (ie, mangiferin, norathyriol, gallotannins, gallic acid, pyrogallol, methyl gallate and quercetin) in preclinical models of breast cancer. Overall, there was a reduction in cell viability, proliferation, growth, migration and invasion as well as an induction of apoptosis and cell cycle arrest. Reduced tumor weight and volume were also observed. A number of mechanisms have been proposed so far: activation of oxidative stress-induced cell death, antioxidant activity, modulation of PPARs, suppression of P13K/AKT pathway, induction of miR-126 expression, inhibition of aromatase enzymatic activity and expression, modulation of intracellular $\mathrm{Ca}^{2+}$ signalling, inhibition of NFKB signalling pathway, inactivation of $\beta$-catenin pathway, inhibition of HMG-CoA reductase, proteasome and plasmin enzymatic activities, inhibition 
of Rac1/WAVE2 signalling pathway, modulation of ER activity, activation of AMPK signalling pathway as well as modulation of cell cycle regulators.

Further selective compound studies should be performed on $M$. indica extracts that possess anti-breast cancer activities to identify and validate phytochemicals that are responsible for the observed bioactivities. Extracts of different $M$. indica parts showed different bioactivities, suggesting variabilities in the type and amount of phytochemicals and thus highlighting the importance of targeting certain plant parts. Additionally, variabilities in bioactivities have also been observed for $M$. indica extracts despite utilisation of the same plant parts, indicating the presence of different phytochemical profiles in these extracts and further emphasizing the importance of selecting the right $M$. indica varieties, extraction method and extraction solvent. Once identified and validated, the phytochemical(s) of interest should be isolated for subsequent studies on their efficacies, toxicities, mechanisms of action and drug metabolism and pharmacokinetics (DMPK) profiles. It has been supported by various studies that multiple $M$. indica phytochemicals may act synergistically such that their combined anti-breast cancer efficacy is higher than that of a single phytochemical, suggesting the potential benefits of their combined usage in cancer treatment. Furthermore, while $M$. indica fruit consumption may be beneficial for women's health in relation to breast cancer given the reported anti-breast cancer activities of $M$. indica pulp extracts, further bioavailability studies are required to determine whether the bioactive compounds within the fruits exhibit reasonable bioavailability to exert their anti-cancer effects following fruit consumption. More committed studies, particularly clinical trials, are needed to explore the anti-breast cancer potential of $M$. indica extracts and their phytochemicals in order to validate their utility in the development of unique and potent therapeutic agents to treat breast cancer. Apart from that, the phytochemicals that are present in $M$. indica extracts may vary in concentration depending on the food source and season, hence the development of health supplements is a better option for consistent deliveries. Furthermore, chemotherapeutic agents lack tumor selectivity such that they may damage normal cells and cause major side effects. Therefore, targeted delivery of bioactive compounds to tumors is required to minimise toxicity to normal cells. Drug delivery techniques based on nanofibers have recently emerged as a potential platform for delivering bioactive compounds to tumor sites. Nanofibers cross-linked with polyphenols from $M$. indica can be coupled to PNIPAAm-PEG-Tat to enable smart tumor microenvironment-responsive targeted distribution of $M$. indica polyphenols. Because of their ability to deliver medicines and genes intracellularly, arginine-rich cell-penetrating peptides (CPPs) like transactivating transcriptional activator (TAT) have attracted a lot of attention (Figure 8). On the other hand, indepth study into alternative delivery systems should be examined as a possibility for optimizing localisation at tumor target areas and therefore boosting therapeutic efficacy.

\section{Consent for Publication}

The final version of the manuscript was reviewed by all the authors who consented to its submission.

\section{Acknowledgments}

The authors appreciate Universiti Kuala Lumpur Royal College of Medicine Perak, Ipoh, Perak, Malaysia, for providing the facilities and services required to complete the study. Figures were created with the support of https:// biorender.com under the paid subscription.

\section{Author Contributions}

All authors made substantial contributions to conception and design, acquisition of data, or analysis and interpretation of data; took part in drafting the article or revising it critically for important intellectual content; agreed to submit to the current journal; gave final approval of the version to be published; and agree to be accountable for all aspects of the work.

\section{Funding}

There is no funding to report.

\section{Disclosure}

The authors have no conflict of interest associated with the publication. There is also no significant financial support for this work.

\section{References}

1. Siegel RL, Miller KD, Jemal A. Cancer statistics, 2016. CA Cancer J Clin. 2016;66(1):7-30. doi:10.3322/caac.21332

2. Sung H, Ferlay J, Siegel RL, et al. Global cancer statistics 2020 : GLOBOCAN estimates of incidence and mortality worldwide for 36 cancers in 185 countries. CA Cancer J Clin. 2021;71(3):209-249. doi: $10.3322 /$ caac. 21660

3. Kennecke H, Yerushalmi R, Woods R, et al. Metastatic behavior of breast cancer subtypes. J Clin Oncol. 2010;28(20):3271-3277. doi:10.1200/JCO.2009.25.9820 
4. Sun YS, Zhao Z, Yang ZN, et al. Risk factors and preventions of breast cancer. Int $J$ Biol Sci. 2017;13(11):1387-1397. doi:10.7150/ijbs. 21635

5. Abu-Helalah M, Azab B, Mubaidin R, et al. BRCA1 and BRCA2 genes mutations among high risk breast cancer patients in Jordan. Sci Rep. 2020;10(1):17573. doi:10.1038/ s41598-020-74250-2

6. Larsen MJ, Thomassen M, Gerdes AM, Kruse TA. Hereditary breast cancer: clinical, pathological and molecular characteristics. Breast Cancer (Auckl). 2014;8:145-155.

7. Koren S, Bentires-Alj M. Breast tumor heterogeneity: source of fitness, hurdle for therapy. Mol Cell. 2015;60(4):537-546. doi:10.1016/j.molcel.2015.10.031

8. Nielsen TO, Hsu FD, Jensen K, et al. Immunohistochemical and clinical characterization of the basal-like subtype of invasive breast carcinoma. Clin Cancer Res. 2004;10(16):5367-5374. doi:10.1158/1078-0432.CCR-04-0220

9. Waks AG, Winer EP. Breast cancer treatment: a review. JAMA. 2019;321(3):288-300. doi:10.1001/jama.2018.19323

10. Fragomeni SM, Sciallis A, Jeruss JS. Molecular subtypes and local-regional control of breast cancer. Surg Oncol Clin N Am. 2018;27(1):95-120. doi:10.1016/j.soc.2017.08.005

11. Lei JT, Anurag M, Haricharan S, Gou X, Ellis MJ. Endocrine therapy resistance: new insights. Breast. 2019;48(Suppl 1):S26S30. doi:10.1016/S0960-9776(19)31118-X

12. Aysola K, Desai A, Welch C, et al. Triple negative breast cancer an overview. Hereditary Genet. 2013;Suppl 2:1.

13. Mukherjee AK, Basu S, Sarkar N, Ghosh AC. Advances in cancer therapy with plant based natural products. Curr Med Chem. 2001;8(12):1467-1486. doi:10.2174/0929867013372094

14. Mondal S, Bandyopadhyay S, Ghosh MK, Mukhopadhyay S, Roy S, Mandal C. Natural products: promising resources for cancer drug discovery. Anticancer Agents Med Chem. 2012;12(1):49-75. doi:10.2174/187152012798764697

15. Bonofiglio D, Giordano C, De Amicis F, Lanzino M, Andò S Natural products as promising antitumoral agents in breast cancer: mechanisms of action and molecular targets. Mini Rev Med Chem. 2016;16(8):596-604. doi:10.2174/ 1389557515666150709110959

16. Khalid F, Nawaz H, Hanif MA, Rehman R, Al-Sadi AM. Mango. Medicinal Plants of South Asia: Novel Sources for Drug Discovery. Amsterdam, Oxford, Cambridge MA: Elsevier; 2020:495-508.

17. Masibo M, He Q. Major mango polyphenols and their potential significance to human health. Compr Rev Food Sci Food Saf. 2008;7(4):309-319. doi:10.1111/j.1541-4337.2008.00047.x

18. Derese S, Guantai EM, Souaibou Y, Kuete V. Mangifera indica L. (Anacardiaceae). Medicinal Spices and Vegetables from Africa. London, San Diego, Cambridge MA, Oxford: Elsevier; 2017:451-483.

19. Shah KA, Patel MB, Patel RJ, Parmar PK. Mangifera indica (Mango). Pharmacogn Rev. 2010;4(7):42-48. doi:10.4103/09737847.65325

20. El-Gied AAA, Joseph MR, Mahmoud IM, Abdelkareem AM, Al Hakami AM, Hamid ME. Antimicrobial activities of seed extracts of mango (Mangifera indica L.). Adv Microbiol. 2012;2(4):571576. doi:10.4236/aim.2012.24074

21. Kabuki T, Nakajima H, Arai M, Ueda S, Kuwabara Y, Dosako S. Characterization of novel antimicrobial compounds from mango (Mangifera indica L.) kernel seeds. Food Chem. 2000;71(1):6166. doi:10.1016/S0308-8146(00)00126-6

22. Makare N, Bodhankar S, Rangari V. Immunomodulatory activity of alcoholic extract of Mangifera indica L. in mice. $J$ Ethnopharmacol. 2001;78(2-3):133-137. doi:10.1016/S03788741(01)00326-9
23. Martinez G, Delgado R, Pérez G, Garrido G, Núñez-Sellés A, León OS. Evaluation of the in vitro antioxidant activity of Mangifera indica L. extract (Vimang). Phytother Res. 2000;14 (6):424-427. doi:10.1002/1099-1573(200009)14:6<424::AIDPTR643>3.0.CO;2-8

24. Banerjee N, Kim H, Krenek K, Talcott ST, Mertens-Talcott SU. Mango polyphenolics suppressed tumor growth in breast cancer xenografts in mice: role of the PI3K/AKT pathway and associated microRNAs. Nutr Res. 2015;35(8):744-751. doi:10.1016/j. nutres.2015.06.002

25. García-Solís P, Yahia EM, Morales-Tlalpan V, Díaz-Muñoz M. Screening of antiproliferative effect of aqueous extracts of plant foods consumed in Mexico on the breast cancer cell line MCF-7. Int J Food Sci Nutr. 2009;60(Suppl 6):32-46. doi:10.1080/ 09637480802312922

26. Wilkinson AS, Flanagan BM, Pierson JT, et al. Bioactivity of mango flesh and peel extracts on peroxisome proliferator-activated receptor $\gamma[\mathrm{PPAR} \gamma]$ activation and MCF-7 cell proliferation: fraction and fruit variability. J Food Sci. 2011;76(1):H11-H18. doi:10.1111/j.1750-3841.2010.01899.x

27. Fernández-Ponce MT, López-Biedma A, Sánchez-Quesada C, et al. Selective antitumoural action of pressurized mango leaf extracts against minimally and highly invasive breast cancer. Food Funct. 2017;8(10):3610-3620. doi:10.1039/ C7FO00877E

28. López-Ríos L, Wiebe JC, Vega-Morales T, Gericke N. Central nervous system activities of extract Mangifera indica L. $J$ Ethnopharmacol. 2020;260:112996. doi:10.1016/j.jep.2020. 112996

29. Venancio VP, Kim H, Sirven MA, et al. Polyphenol-rich mango (Mangifera indica L.) ameliorate functional constipation symptoms in humans beyond equivalent amount of fiber. Mol Nutr Food Res. 2018;62(12):e1701034. doi:10.1002/mnfr.201701034

30. Anaya-Loyola MA, García-Marín G, García-Gutiérrez DG, et al. A mango (Mangifera indica L.) juice by-product reduces gastrointestinal and upper respiratory tract infection symptoms in children. Food Res Int. 2020;136:109492. doi:10.1016/j. foodres.2020.109492

31. López Mantecón AM, Garrido G, Delgado-Hernández R, Garrido-Suárez BB. Combination of Mangifera indica L. extract supplementation plus methotrexate in rheumatoid arthritis patients: a pilot study. Phytother Res. 2014;28(8):1163-1172. doi:10.1002/ptr.5108

32. Rodeiro I, Donato MT, Jiménez N, Garrido G, Delgado R, Gómez-Lechón MJ. Effects of Mangifera indica L. aqueous extract (Vimang) on primary culture of rat hepatocytes. Food Chem Toxicol. 2007;45(12):2506-2512. doi:10.1016/j.fct.2007. 05.027

33. Núñez Sellés AJ, Vélez Castro HT, Agüero-Agüero J, et al. Isolation and quantitative analysis of phenolic antioxidants, free sugars, and polyols from mango (Mangifera indica L.) stem bark aqueous decoction used in Cuba as a nutritional supplement. J Agric Food Chem. 2002;50(4):762-766. doi:10.1021/jf011064b

34. García-Rivera D, Delgado R, Bougarne N, Haegeman G, Berghe WV. Gallic acid indanone and mangiferin xanthone are strong determinants of immunosuppressive anti-tumour effects of Mangifera indica L. bark in MDA-MB231 breast cancer cells. Cancer Lett. 2011;305(1):21-31. doi:10.1016/j. canlet.2011.02.011

35. Pardo-Andreu GL, Dorta DJ, Delgado R, et al. Vimang (Mangifera indica L. extract) induces permeability transition in isolated mitochondria, closely reproducing the effect of mangiferin, Vimang's main component. Chem Biol Interact. 2006;159 (2):141-148. doi:10.1016/j.cbi.2005.10.109 
36. Garrido G, González D, Delporte C, et al. Analgesic and antiinflammatory effects of Mangifera indica L. extract (Vimang). Phytother Res. 2001;15(1):18-21. doi:10.1002/1099-1573 (200102)15:1<18::AID-PTR676>3.0.CO;2-R

37. Garrido G, Blanco-Molina M, Sancho R, Macho A, Delgado R, Muñoz E. An aqueous stem bark extract of Mangifera indica (Vimang) inhibits T cell proliferation and TNF-induced activation of nuclear transcription factor NF-kappaB. Phytother Res. 2005;19(3):211-215. doi:10.1002/ptr.1656

38. Tamayo D, Mari E, Gonzalez S, et al. Vimang as natural antioxidant supplementation in patients with malignant tumors. Minerva Med. 2001;92(Suppl 1-3):95-97.

39. Abdullah AH, Mohammed AS, Abdullah R, Mirghani MES, AlQubaisi M. Cytotoxic effects of Mangifera indica L. kernel extract on human breast cancer (MCF-7 and MDA-MB-231 cell lines) and bioactive constituents in the crude extract. $B M C$ Complement Altern Med. 2014;14(1):199. doi:10.1186/14726882-14-199

40. Black HS, Mathews-Roth MM. Cytotoxicity and apoptosis induction by butylated hydroxyanisole (BHA) and butylated hydroxytoluene (BHT). Photochem Photobiol. 1991;53(5):707-716. doi:10.1111/j.1751-1097.1991.tb08501.x

41. Saito M, Sakagami H, Fujisawa S. Cytotoxicity and apoptosis induction by butylated hydroxyanisole (BHA) and butylated hydroxytoluene (BHT). Anticancer Res. 2003;23(6C):46934701.

42. Kuroda K, Akao M. Antitumor and anti-intoxication activities of fumaric acid in cultured cells. Gan. 1981;72(5):777-782.

43. Kuroda K, Terao K, Akao M. Inhibitory effect of fumaric acid on hepatocarcinogenesis by thioacetamide in rats. $J$ Natl Cancer Inst. 1987;79(5):1047-1051.

44. Okokon JE, Dar A, Choudhary MI. Immunomodulatory, cytotoxic and antileishmanial activity of phytoconstituents of Croton zambesicus. Phytopharmacol. 2013;4(1):31-40.

45. Smiljkovic M, Stanisavljevic D, Stojkovic D, et al. Apigenin7-O-glucoside versus apigenin: insight into the modes of anticandidal and cytotoxic actions. EXCLI J. 2017;16:795807.

46. Srivastava J, Gupta S. Anti-proliferative and apoptotic effects of chamomile extract in various human cancer cells. J Agric Food Chem. 2007;55(23):9470-9478. doi:10.1021/jf071953k

47. Posner GH, Ploypradith P, Hapangama W, et al. Trioxane dimers have potent antimalarial, antiproliferative and antitumor activities in vitro. Bioorg Med Chem. 1997;5(7):1257-1265. doi:10.1016/ S0968-0896(97)00079-5

48. Shacter E, Weitzman SA. Chronic inflammation and cancer. Oncology. 2002;16(2):217-226, 229.

49. Barreto JC, Trevisan MTS, Hull WE, et al. Characterization and quantitation of polyphenolic compounds in bark, kernel, leaves, and peel of mango (Mangifera indica L.). J Agric Food Chem. 2008;56(14):5599-5610. doi:10.1021/jf800738r

50. Ganogpichayagrai A, Palanuvej C, Ruangrungsi N. Antidiabetic and anticancer activities of Mangifera indica $\mathrm{cv}$. Okrong leaves. $J$ Adv Pharm Technol Res. 2017;8(1):19-24. doi:10.4103/22314040.197371

51. Shaban NZ, Hegazy WA, Abdel-Rahman SM, Awed OM, Khalil SA. Potential effect of Olea europaea leaves, Sonchus oleraceus leaves and Mangifera indica peel extracts on aromatase activity in human placental microsomes and CYP19A1 expression in MCF-7 cell line: comparative study. Cell Mol Biol (Noisy-Le-Grand). 2016;62(9):11-19.

52. Hoang VLT, Pierson JT, Curry MC, et al. Polyphenolic contents and the effects of methanol extracts from mango varieties on breast cancer cells. Food Sci Biotechnol. 2015;24(1):265-271. doi:10.1007/s10068-015-0035-x
53. Taing MW, Pierson JT, Shaw PN, et al. Mango fruit extracts differentially affect proliferation and intracellular calcium signalling in MCF-7 human breast cancer cells. $J$ Chem. 2015;2015:110. doi: $10.1155 / 2015 / 613268$

54. Pierson JT, Monteith GR, Roberts-Thomson SJ, Dietzgen RG, Gidley MJ, Shaw PN. Phytochemical extraction, characterisation and comparative distribution across four mango (Mangifera indica L.) fruit varieties. Food Chem. 2014;149:253-263. doi:10.1016/j.foodchem.2013.10.108

55. Noratto GD, Bertoldi MC, Krenek K, Talcott ST, Stringheta PC, Mertens-Talcott SU. Anticarcinogenic effects of polyphenolics from mango (Mangifera indica) varieties. J Agric Food Chem. 2010;58(7):4104-4112. doi:10.1021/jf903161g

56. Nemec MJ, Kim H, Marciante AB, Barnes RC, Talcott ST, Mertens-Talcott SU. Pyrogallol, an absorbable microbial gallotannins-metabolite and mango polyphenols (Mangifera Indica L.) suppress breast cancer ductal carcinoma in situ proliferation in vitro. Food Funct. 2016;7(9):3825-3833. doi:10.1039/ C6FO00636A

57. Nemec MJ, Kim H, Marciante AB, et al. Polyphenolics from mango (Mangifera indica L.) suppress breast cancer ductal carcinoma in situ proliferation through activation of AMPK pathway and suppression of mTOR in athymic nude mice. $J$ Nutr Biochem. 2017;41:12-19. doi:10.1016/j. jnutbio.2016.11.005

58. Benard O, Chi Y. Medicinal properties of mangiferin, structural features, derivative synthesis. Pharmacokinetics Biol Activities Mini Rev Med Chem. 2015;15(7):582-594. doi:10.2174/ 1389557515666150401111410

59. Biswas T, Sen A, Roy R, Maji S, Maji HS. Isolation of mangiferin from flowering buds of Mangifera indica $\mathrm{L}$ and its evaluation of in vitro antibacterial activity. J Pharm Anal. 2015;4(3):4956.

60. Dar A, Faizi S, Naqvi S, et al. Analgesic and antioxidant activity of mangiferin and its derivatives: the structure activity relationship. Biol Pharm Bull. 2005;28(4):596-600. doi:10.1248/ bpb.28.596

61. Gong X, Zhang L, Jiang R, Ye M, Yin X, Wan J. Anti-inflammatory effects of mangiferin on sepsis-induced lung injury in mice via up-regulation of heme oxygenase-1. J Nutr Biochem. 2013;24 (6):1173-1181. doi:10.1016/j.jnutbio.2012.09.003

62. Miura T, Ichiki H, Hashimoto I, et al. Antidiabetic activity of a xanthone compound, mangiferin. Phytomedicine. 2001;8(2):8587. doi:10.1078/0944-7113-00009

63. Núñez Selles AJ, Daglia M, Rastrelli L. The potential role of mangiferin in cancer treatment through its immunomodulatory, anti-angiogenic, apoptopic, and gene regulatory effects. Biofactors. 2016;42(5):475-491. doi:10.1002/biof.1299

64. Rajendran $P$, Jayakumar $\mathrm{T}$, Nishigaki $\mathrm{I}$, et al. Immunomodulatory effect of mangiferin in experimental animals with benzo(a)pyrene-induced lung carcinogenesis. Int $J$ Biomed Sci. 2013;9(2):68-74.

65. Imran M, Arshad MS, Butt MS, Kwon JH, Arshad MU, Sultan MT. Mangiferin: a natural miracle bioactive compound against lifestyle related disorders. Lipids Health Dis. 2017;16(1):84. doi:10.1186/s12944-017-0449-y

66. Li H, Huang J, Yang B, et al. Mangiferin exerts antitumor activity in breast cancer cells by regulating matrix metalloproteinases, epithelial to mesenchymal transition, and $\beta$-catenin signaling pathway. Toxicol Appl Pharmacol. 2013;272(1):180-190. doi:10.1016/j.taap.2013.05.011

67. Deng Q, Tian YX, Liang J. Mangiferin inhibits cell migration and invasion through Rac1/WAVE2 signalling in breast cancer. Cytotechnology. 2018;70(2):593-601. doi:10.1007/s10616-0170140-1 
68. Cuccioloni M, Bonfili L, Mozzicafreddo M, et al. Mangiferin blocks proliferation and induces apoptosis of breast cancer cells via suppression of mevalonate pathway and by proteasome inhibition. Food Funct. 2016;7(10):4299-4309. doi:10.1039/ C6FO01037G

69. Thorn CF, Oshiro C, Marsh S, et al. Doxorubicin pathways: pharmacodynamics and adverse effects. Pharmacogenet Genomics. 2011;21(7):440-446. doi:10.1097/ FPC.0b013e32833ffb56

70. Al-Malky HS, Al Harthi SE, Osman AMM. Major obstacles to doxorubicin therapy: cardiotoxicity and drug resistance. J Oncol Pharm Pract. 2020;26(2):434-444. doi:10.1177/ 1078155219877931

71. Mechetner E, Kyshtoobayeva A, Zonis S, et al. Levels of multidrug resistance (MDR1) P-glycoprotein expression by human breast cancer correlate with in vitro resistance to taxol and doxorubicin. Clin Cancer Res. 1998;4(2):389-398.

72. Sargent JM, Williamson CJ, Maliepaard M, Elgie AW, Scheper RJ, Taylor CG. Breast cancer resistance protein expression and resistance to daunorubicin in blast cells from patients with acute myeloid leukaemia. $B r \quad J$ Haematol. 2001;115(2):257-262. doi:10.1046/j.1365-2141.2001.03122.x

73. Zhang YK, Wang YJ, Gupta P, Chen ZS. Multidrug resistance proteins (MRPs) and cancer therapy. AAPS J. 2015;17(4):802812. doi:10.1208/s12248-015-9757-1

74. Louisa M, Soediro TM, Suyatna FD. In vitro modulation of P-glycoprotein, MRP-1 and BCRP expression by mangiferin in doxorubicin-treated MCF-7 cells. Asian Pac J Cancer Prev. 2014;15(4):1639-1642. doi:10.7314/ APJCP.2014.15.4.1639

75. Wilkinson AS, Taing MW, Pierson JT, et al. Estrogen modulation properties of mangiferin and quercetin and the mangiferin metabolite norathyriol. Food Funct. 2015;6(6):1847-1854. doi:10.1039/C5FO00133A

76. Wang F, Yan J, Niu Y, et al. Mangiferin and its aglycone, norathyriol, improve glucose metabolism by activation of AMPactivated protein kinase. Pharm Biol. 2014;52(1):68-73. doi:10.3109/13880209.2013.814691

77. Han B, Yang B, Yang X, et al. Host-guest inclusion system of norathyriol with $\beta$-cyclodextrin and its derivatives: preparation, characterization, and anticancer activity. $J$ Biosci Bioeng. 2014;117(6):775-779. doi:10.1016/j.jbiosc.2013.12.001

78. Sanugul K, Akao T, Li Y, Kakiuchi N, Nakamura N, Hattori M. Isolation of a human intestinal bacterium that transforms mangiferin to norathyriol and inducibility of the enzyme that cleaves a C-glucosyl bond. Biol Pharm Bull. 2005;28(9):1672-1678. doi:10.1248/bpb.28.1672

79. Shi ZL, Liu YD, Yuan YY, et al. In vitro and in vivo effects of norathyriol and mangiferin on $\alpha$-glucosidase. Biochem Res Int. 2017;2017:1206015. doi:10.1155/2017/1206015

80. Wang JP, Ho TF, Lin CN, Teng CM. Effect of norathyriol, isolated from Tripterospermum lanceolatum, on A23187-induced pleurisy and analgesia in mice. Naunyn Schmiedebergs Arch Pharmacol. 1994;350(1):90-95. doi:10.1007/BF00180016

81. Li J, Malakhova M, Mottamal M, et al. Norathyriol suppresses solar UV-induced skin cancer by targeting ERKs. Cancer Res. 2012;72(1):260-270. doi:10.1158/0008-5472.CAN-11-2596

82. Teng CM, Ko FN, Wang JP, et al. Antihaemostatic and antithrombotic effect of some antiplatelet agents isolated from Chinese herbs. J Pharm Pharmacol. 1991;43(9):667-669. doi:10.1111/ j.2042-7158.1991.tb03561.x

83. Ko FN, Lin CN, Liou SS, Huang TF, Teng CM. Vasorelaxation of rat thoracic aorta caused by norathyriol isolated from Gentianaceae. Eur J Pharmacol. 1991;192(1):133-139. doi:10.1016/0014-2999(91)90079-6
84. Barnes RC, Kim H, Fang C, et al. Body mass index as a determinant of systemic exposure to gallotannin metabolites during 6-week consumption of mango (Mangifera indica L.) and modulation of intestinal microbiota in lean and obese individuals. Mol Nutr Food Res. 2019;63(2):e1800512. doi:10.1002/mnfr.201800512

85. Farràs M, Martinez-Gili L, Portune K, et al. Modulation of the gut microbiota by olive oil phenolic compounds: implications for lipid metabolism, immune system, and obesity. Nutrients. 2020;12(8):2200. doi:10.3390/nu12082200

86. Gali HU, Perchellet EM, Gao XM, Bottari V, Perchellet JP. Antitumor-promoting effects of gallotannins extracted from various sources in mouse skin in vivo. Anticancer Res. 1993;13(4):915-922.

87. Huh JE, Lee EO, Kim MS, et al. Penta-O-galloyl-beta-D-glucose suppresses tumor growth via inhibition of angiogenesis and stimulation of apoptosis: roles of cyclooxygenase- 2 and mitogenactivated protein kinase pathways. Carcinogenesis. 2005;26 (8):1436-1445. doi:10.1093/carcin/bgi097

88. Mizushina Y, Zhang J, Pugliese A, Kim SH, Lü J. Anti-cancer gallotannin penta-O-galloyl-beta-D-glucose is a nanomolar inhibitor of select mammalian DNA polymerases. Biochem Pharmacol. 2010;80(8):1125-1132. doi:10.1016/j.bcp.2010.06.031

89. Mohan CG, Viswanatha GL, Savinay G, Rajendra CE, Halemani PD. 1,2,3,4,6 Penta-O-galloyl- $\beta$-d-glucose, a bioactivity guided isolated compound from Mangifera indica inhibits $11 \beta$-HSD-1 and ameliorates high fat diet-induced diabetes in C57BL/6 mice. Phytomedicine. 2013;20(5):417-426. doi:10.1016/j. phymed.2012.12.020

90. Erdèlyi K, Kiss A, Bakondi E, et al. Gallotannin inhibits the expression of chemokines and inflammatory cytokines in A549 cells. Mol Pharmacol. 2005;68(3):895-904. doi:10.1124/ mol.105.012518

91. Engels C, Knödler M, Zhao YY, Carle R, Gänzle MG, Schieber A. Antimicrobial activity of gallotannins isolated from mango (Mangifera indica L.) kernels. J Agric Food Chem. 2009;57 (17):7712-7718. doi:10.1021/jf901621m

92. Cai Y, Luo Q, Sun M, Corke H. Antioxidant activity and phenolic compounds of 112 traditional Chinese medicinal plants associated with anticancer. Life Sci. 2004;74(17):2157-2184. doi:10.1016/j. Ifs.2003.09.047

93. Lim KJA, Cabajar AA, Lobarbio CFY, Taboada EB, Lacks DJ. Extraction of bioactive compounds from mango (Mangifera indica L. var. Carabao) seed kernel with ethanol-water binary solvent systems. J Food Sci Technol. 2019;56(5):2536-2544. doi:10.1007/s13197-019-03732-7

94. Hua KT, Way TD, Lin JK. Pentagalloylglucose inhibits estrogen receptor alpha by lysosome-dependent depletion and modulates ErbB/PI3K/Akt pathway in human breast cancer MCF-7 cells. Mol Carcinog. 2006;45(8):551-560. doi:10.1002/mc.20226

95. Chen WJ, Chang CY, Lin JK. Induction of G1 phase arrest in MCF human breast cancer cells by pentagalloylglucose through the downregulation of CDK4 and CDK2 activities and up-regulation of the CDK inhibitors p27(Kip) and p21(Cip). Biochem Pharmacol. 2003;65(11):1777-1785. doi:10.1016/S0006-2952(03)00156-4

96. Kahkeshani N, Farzaei F, Fotouhi M, et al. Pharmacological effects of gallic acid in health and diseases: a mechanistic review. Iran J Basic Med Sci. 2019;22(3):225-237.

97. Kim SH, Jun CD, Suk K, et al. Gallic acid inhibits histamine release and pro-inflammatory cytokine production in mast cells. Toxicol Sci. 2006;91(1):123-131. doi:10.1093/toxsci/kfj063

98. Kroes BH. Anti-inflammatory activity of gallic acid. Planta Med. 1992;58(6):499-504. doi:10.1055/s-2006-961535

99. Sorrentino E, Succi M, Tipaldi L, et al. Antimicrobial activity of gallic acid against food-related Pseudomonas strains and its use as biocontrol tool to improve the shelf life of fresh black truffles. Int J Food Microbiol. 2018;266:183-189. doi:10.1016/j. ijfoodmicro.2017.11.026 
100. Gichner T, Pospísil F, Velemínský J, Volkeová V, Volke J. Two types of antimutagenic effects of gallic and tannic acids towards $\mathrm{N}$-nitroso-compounds-induced mutagenicity in the Ames Salmonella assay. Folia Microbiol (Praha). 1987;32(1):55-62. doi:10.1007/BF02877259

101. Velderrain-Rodríguez GR, Torres-Moreno H, Villegas-Ochoa $\mathrm{MA}$, et al. Gallic acid content and an antioxidant mechanism are responsible for the antiproliferative activity of 'Ataulfo' mango peel on LS180 cells. Molecules. 2018;23(3):695. doi:10.3390/molecules23030695

102. Zhao B, Hu M. Gallic acid reduces cell viability, proliferation, invasion and angiogenesis in human cervical cancer cells. Oncol Lett. 2013;6(6):1749-1755. doi:10.3892/ol.2013.1632

103. Subramanian AP, Jaganathan SK, Mandal M, Supriyanto E, Muhamad II. Gallic acid induced apoptotic events in HCT-15 colon cancer cells. World J Gastroenterol. 2016;22(15):39523961. doi:10.3748/wjg.v22.i15.3952

104. Faried A, Kurnia D, Faried LS, et al. Anticancer effects of gallic acid isolated from Indonesian herbal medicine, Phaleria macrocarpa (Scheff.) Boerl, on human cancer cell lines. Int J Oncol. 2007;30(3):605-613.

105. Tsai CL, Chiu YM, Ho TY, et al. Gallic acid induces apoptosis in human gastric adenocarcinoma cells. Anticancer Res. 2018;38 (4):2057-2067.

106. Lu Y, Jiang F, Jiang H, et al. Gallic acid suppresses cell viability, proliferation, invasion and angiogenesis in human glioma cells. Eur $J$ Pharmacol. 2010;641(2-3):102-107. doi:10.1016/j. ejphar.2010.05.043

107. Gu R, Zhang M, Meng H, Xu D, Xie Y. Gallic acid targets acute myeloid leukemia via Akt/mTOR-dependent mitochondrial respiration inhibition. Biomed Pharmacother. 2018;105:491497. doi:10.1016/j.biopha.2018.05.158

108. Sun G, Zhang S, Xie Y, Zhang Z, Zhao W. Gallic acid as a selective anticancer agent that induces apoptosis in SMMC-7721 human hepatocellular carcinoma cells. Oncol Lett. 2016;11 (1):150-158. doi:10.3892/ol.2015.3845

109. Zhang T, Ma L, Wu P, et al. Gallic acid has anticancer activity and enhances the anticancer effects of cisplatin in non-small cell lung cancer A549 cells via the JAK/STAT3 signaling pathway. Oncol Rep. 2019;41(3):1779-1788.

110. Jang YG, Ko EB, Choi KC. Gallic acid, a phenolic acid, hinders the progression of prostate cancer by inhibition of histone deacetylase 1 and 2 expression. J Nutr Biochem. 2020;84:108444. doi:10.1016/j.jnutbio.2020.108444

111. Hsu JD, Kao SH, Ou TT, Chen YJ, Li YJ, Wang CJ. Gallic acid induces G2/M phase arrest of breast cancer cell MCF-7 through stabilization of p27(Kip1) attributed to disruption of p27(Kip1)/ Skp2 complex. J Agric Food Chem. 2011;59(5):1996-2003. doi:10.1021/jf103656v

112. Wang $\mathrm{K}$, Zhu X, Zhang K, Zhu L, Zhou F. Investigation of gallic acid induced anticancer effect in human breast carcinoma MCF-7 cells. J Biochem Mol Toxicol. 2014;28(9):387-393. doi:10.1002/ jbt. 21575

113. Ozturk Sarikaya SB. Acetylcholinesterase inhibitory potential and antioxidant properties of pyrogallol. J Enzyme Inhib Med Chem. 2015;30(5):761-766. doi:10.3109/14756366.2014.965700

114. National Toxicology Program. Toxicology and carcinogenesis studies of pyrogallol (CAS No. 87-66-1) in F344/N rats and B6C3F1/N mice (dermal studies). Natl Toxicol Program Tech Rep Ser. 2013;574:1-167.

115. Nicolis E, Lampronti I, Dechecchi MC, et al. Pyrogallol, an active compound from the medicinal plant Emblica officinalis, regulates expression of pro-inflammatory genes in bronchial epithelial cells. Int Immunopharmacol. 2008;8(12):1672-1680. doi:10.1016/j.intimp.2008.08.001
116. Kocaçalişkan I, Talan I, Terzi I. Antimicrobial activity of catechol and pyrogallol as allelochemicals. $Z$ Naturforsch $C J$ Biosci. 2006;61(9-10):639-642. doi:10.1515/znc-2006-9-1004

117. Ahn H, Im E, Lee DY, Lee HJ, Jung JH, Kim SH. Antitumor effect of pyrogallol via miR-134 mediated $\mathrm{S}$ phase arrest and inhibition of $\mathrm{PI} 3 \mathrm{~K} / \mathrm{AKT} / \mathrm{Skp} 2 / \mathrm{cMyc}$ signaling in hepatocellular carcinoma. Int $J$ Mol Sci. 2019;20(16):3985. doi:10.3390/ijms20163985

118. Park WH, Park MN, Han YH, Kim SW. Pyrogallol inhibits the growth of gastric cancer SNU-484 cells via induction of apoptosis. Int J Mol Med. 2008;22(2):263-268.

119. Revathi S, Hakkim FL, Ramesh Kumar N, et al. In vivo anti cancer potential of pyrogallol in murine model of colon cancer. Asian Pac J Cancer Prev. 2019;20(9):2645-2651. doi:10.31557/ APJCP.2019.20.9.2645

120. Yang CJ, Wang CS, Hung JY, et al. Pyrogallol induces G2-M arrest in human lung cancer cells and inhibits tumor growth in an animal model. Lung Cancer. 2009;66(2):162-168. doi:10.1016/j. lungcan.2009.01.016

121. Abou-Zaid MM, Lombardo DA, Nozzolillo C. Methyl gallate is a natural constituent of maple (Genus Acer) leaves. Nat Prod Res. 2009;23(15):1373-1377. doi:10.1080/14786410802420457

122. Chaudhuri D, Ghate NB, Singh SS, Mandal N. Methyl gallate isolated from Spondias pinnata exhibits anticancer activity against human glioblastoma by induction of apoptosis and sustained extracellular signal-regulated kinase 1/2 activation. Pharmacogn Mag. 2015;11(42):269-276. doi:10.4103/0973-1296.153078

123. Mishra RK, Ramakrishna M, Mishra V, et al. Pharmaco-phylogenetic investigation of methyl gallate isolated from Acacia nilotica (L.) Delile and Its cytotoxic effect on NIH3T3 mouse fibroblast. Curr Pharm Biotechnol. 2016;17(6):540-548. doi:10.2174/ 1389201017666160127110759

124. Wang CR, Zhou R, Ng TB, Wong JH, Qiao WT, Liu F. First report on isolation of methyl gallate with antioxidant, anti-HIV-1 and HIV-1 enzyme inhibitory activities from a mushroom (Pholiota adiposa). Environ Toxicol Pharmacol. 2014;37(2):626637. doi:10.1016/j.etap.2014.01.023

125. Rahman N, Jeon M, Kim YS. Methyl gallate, a potent antioxidant inhibits mouse and human adipocyte differentiation and oxidative stress in adipocytes through impairment of mitotic clonal expansion. Biofactors. 2016;42(6):716-726. doi:10.1002/biof.1310

126. Kamatham S, Kumar N, Gudipalli P. Isolation and characterization of gallic acid and methyl gallate from the seed coats of Givotia rottleriformis Griff. and their anti-proliferative effect on human epidermoid carcinoma A431 cells. Toxicol Rep. 2015;2:520-529. doi:10.1016/j.toxrep.2015.03.001

127. Lee H, Lee $\mathrm{H}$, Kwon $\mathrm{Y}$, et al. Methyl gallate exhibits potent antitumor activities by inhibiting tumor infiltration of CD4 +CD25+ regulatory T cells. J Immunol. 2010;185(11):66986705. doi:10.4049/jimmunol.1001373

128. Choi JG, Kang OH, Lee YS, et al. In vitro activity of methyl gallate isolated from galla rhois alone and in combination with ciprofloxacin against clinical isolates of salmonella. $J$ Microbiol Biotechnol. 2008;18(11):1848-1852.

129. Kane CJ, Menna JH, Sung CC, Yeh YC. Methyl gallate, methyl3,4,5-trihydroxybenzoate, is a potent and highly specific inhibitor of herpes simplex virus in vitro. II. Antiviral activity of methyl gallate and its derivatives. Biosci Rep. 1988;8(1):95-102. doi:10.1007/BF01128976

130. Correa LB, Seito LN, Manchope MF, et al. Methyl gallate attenuates inflammation induced by Toll-like receptor ligands by inhibiting MAPK and NF-Kb signaling pathways. Inflamm Res. 2020;69(12):1257-1270. doi:10.1007/s00011-020-01407-0

131. Asnaashari M, Farhoosh R, Sharif A. Antioxidant activity of gallic acid and methyl gallate in triacylglycerols of Kilka fish oil and its oil-in-water emulsion. Food Chem. 2014;159:439-444. doi:10.1016/j.foodchem.2014.03.038 
132. Li Y, Yao J, Han C, et al. Quercetin, Inflammation and Immunity. Nutrients. 2016;8(3):167. doi:10.3390/nu8030167

133. Ji JJ, Lin Y, Huang SS, Zhang HL, Diao YP, Li K. Quercetin: a potential natural drug for adjuvant treatment of rheumatoid arthritis. Afr J Tradit Complement Altern Med. 2013;10(3):418-421.

134. Bule M, Abdurahman A, Nikfar S, Abdollahi M, Amini M. Antidiabetic effect of quercetin: a systematic review and metaanalysis of animal studies. Food Chem Toxicol. 2019;125:494502. doi:10.1016/j.fct.2019.01.037

135. Wang S, Yao J, Zhou B, et al. Bacteriostatic effect of quercetin as an antibiotic alternative in vivo and its antibacterial mechanism in vitro. J Food Prot. 2018;81(1):68-78. doi:10.4315/0362-028X.JFP-17214

136. Comalada M, Camuesco D, Sierra S, et al. In vivo quercitrin antiinflammatory effect involves release of quercetin, which inhibits inflammation through down-regulation of the NF-kappaB pathway. Eur J Immunol. 2005;35(2):584-592. doi:10.1002/eji.200425778

137. Song X, Wang Y, Gao L. Mechanism of antioxidant properties of quercetin and quercetin-DNA complex. J Mol Model. 2020;26 (6):133. doi:10.1007/s00894-020-04356-x

138. Alexander SP. Flavonoids as antagonists at A1 adenosine receptors. Phytother Res. 2006;20(11):1009-1012. doi:10.1002/ptr.1975

139. Yin G, Wang Z, Wang Z, Wang X. Topical application of quercetin improves wound healing in pressure ulcer lesions. Exp Dermatol. 2018;27(7):779-786. doi:10.1111/exd.13679

140. Zhang XA, Zhang S, Yin Q, Zhang J. Quercetin induces human colon cancer cells apoptosis by inhibiting the nuclear factor-kappa B pathway. Pharmacogn Mag. 2015;11(42):404-409. doi:10.4103/0973-1296.153096

141. Han C, Gao H, Zhang X. Quercetin anti-cancer effect in renal cancer through regulating survivin expression and caspase 3 activity. Med One. 2016;1(1):3.

142. Dong Y, Yang J, Yang L, Li P. Quercetin inhibits the proliferation and metastasis of human non-small cell lung cancer cell line: the key role of src-mediated fibroblast growth factor-inducible 14 (Fn14)/nuclear factor kappa B (NF-кB) pathway. Med Sci Monit. 2020;26:e920537. doi:10.12659/MSM.920537

143. Ong CS, Tran E, Nguyen TT, et al. Quercetin-induced growth inhibition and cell death in nasopharyngeal carcinoma cells are associated with increase in Bad and hypophosphorylated retinoblastoma expressions. Oncol Rep. 2004;11(3):727-733.

144. Teekaraman D, Elayapillai SP, Viswanathan MP, Jagadeesan A. Quercetin inhibits human metastatic ovarian cancer cell growth and modulates components of the intrinsic apoptotic pathway in PA-1 cell line. Chem Biol Interact. 2019;300:91-100. doi:10.1016/j.cbi.2019.01.008

145. Angst E, Park JL, Moro A, et al. The flavonoid quercetin inhibits pancreatic cancer growth in vitro and in vivo. Pancreas. 2013;42 (2):223-229. doi:10.1097/MPA.0b013e318264ccae

146. Ward AB, Mir H, Kapur N, Gales DN, Carriere PP, Singh S. Quercetin inhibits prostate cancer by attenuating cell survival and inhibiting anti-apoptotic pathways. World J Surg Oncol. 2018;16 (1):108. doi:10.1186/s12957-018-1400-Z

147. Zhang H, Zhang M, Yu L, Zhao Y, He N, Yang X. Antitumor activities of quercetin and quercetin-5, 8-disulfonate in human colon and breast cancer cell lines. Food Chem Toxicol. 2012;50 (5):1589-1599. doi:10.1016/j.fct.2012.01.025

148. Chou CC, Yang JS, Lu HF, et al. Quercetin-mediated cell cycle arrest and apoptosis involving activation of a caspase cascade through the mitochondrial pathway in human breast cancer MCF-7 cells. Arch Pharm Res. 2010;33(8):1181-1191. doi:10.1007/s12272-010-0808-y

149. Chien SY, Wu YC, Chung JG, et al. Quercetin-induced apoptosis acts through mitochondrial- and caspase-3-dependent pathways in human breast cancer MDA-MB-231 cells. Hum Exp Toxicol. 2009;28(8):493-503. doi:10.1177/0960327109107002
150. Rivera Rivera A, Castillo-Pichardo L, Gerena Y, Dharmawardhane S. Anti-breast cancer potential of quercetin via the Akt/AMPK/mammalian target of rapamycin (mTOR) signaling cascade. PLoS One. 2016;11(6):e0157251. doi:10.1371/ journal.pone.0157251

151. Schieber M, Chandel NS. ROS function in redox signaling and oxidative stress. Curr Biol. 2014;24(10):453-462. doi:10.1016/j. cub.2014.03.034

152. Matés JM, Segura JA, Alonso FJ, Márquez J. Intracellular redox status and oxidative stress: implications for cell proliferation, apoptosis, and carcinogenesis. Arch Toxicol. 2008;82(5):273299. doi:10.1007/s00204-008-0304-z

153. Nogueira V, Hay N. Molecular pathways: reactive oxygen species homeostasis in cancer cells and implications for cancer therapy. Clin Cancer Res. 2013;19(16):4309-4314. doi:10.1158/10780432.CCR-12-1424

154. Nimse SB, Pal D. Free radicals, natural antioxidants, and their reaction mechanisms. RSC Adv. 2015;5(35):27986-28006. doi:10.1039/C4RA13315C

155. Burton GJ, Jauniaux E. Oxidative stress. Best Pract Res Clin Obstet Gynaecol. 2011;25(3):287-299. doi:10.1016/j. bpobgyn.2010.10.016

156. Aggarwal V, Tuli HS, Varol A, et al. Role of reactive oxygen species in cancer progression: molecular mechanisms and recent advancements. Biomolecules. 2019;9(11):735. doi:10.3390/ biom 9110735

157. Matés JM, Segura JA, Alonso FJ, Márquez J. Oxidative stress in apoptosis and cancer: an update. Arch Toxicol. 2012;86(11):16491665 .

158. Storz P. Oxidative stress and cancer. In: Jakob U, Reichmann D, editors. Oxidative Stress and Redox Regulation. Berlin: Springer; 2004:427-447.

159. Green DR. Means to an End: Apoptosis and Other Cell Death Mechanisms. Cold Spring Harbor: Cold Spring Harbor Laboratory Press; 2011.

160. Abdullah AH, Mohammed AS, Rasedee A, Mirghani MES. Oxidative stress-mediated apoptosis induced by ethanolic mango seed extract in cultured estrogen receptor positive breast cancer MCF-7 cells. Int J Mol Sci. 2015a;16(2):3528-3536. doi:10.3390/ ijms 16023528

161. Abdullah AH, Mohammed AS, Rasedee A, Mirghani MES, AlQubaisi MS. Induction of apoptosis and oxidative stress in estrogen receptor-negative breast cancer, MDA-MB231 cells, by ethanolic mango seed extract. BMC Compl Alternative Med. 2015b;15:45. doi:10.1186/s12906-015-0575-x

162. Schumacker PT. Reactive oxygen species in cancer cells: live by the sword, die by the sword. Cancer Cell. 2006;10(3):175-176. doi:10.1016/j.ccr.2006.08.015

163. Storz P. Reactive oxygen species in tumor progression. Front Biosci. 2005;10:1881-1896. doi:10.2741/1667

164. Liou GY, Storz P. Reactive oxygen species in cancer. Free Radic Res. 2010;44(5):479-496. doi:10.3109/10715761003667554

165. Fernández-Ponce MT, Casas L, Mantell C. Use of high pressure techniques to produce Mangifera indica L. leaf extracts enriched in potent antioxidant phenolic compounds. Innov Food Sci Emerg Tech. 2015;29:94-106. doi:10.1016/j. ifset.2015.04.006

166. Fernández Ponce MT, Casas L, Mantell C, Rodríguez M. Extraction of antioxidant compounds from different varieties of Mangifera indica leaves using green technologies. J Supercrit Fluids. 2012;72:168-175. doi:10.1016/j.supflu.2012.07.016

167. Tyagi S, Gupta P, Saini AS, Kaushal C, Sharma S. The peroxisome proliferator-activated receptor: a family of nuclear receptors role in various diseases. J Adv Pharm Technol Res. 2011;2 (4):236-240. doi:10.4103/2231-4040.90879 
168. Wagner N, Wagner KD. PPAR Beta/Delta and the Hallmarks of Cancer. Cells. 2020;9(5):1133. doi:10.3390/cells9051133

169. Tachibana K, Yamasaki D, Ishimoto K, Doi T. The role of PPARs in cancer. PPAR Res. 2008;2008:102737. doi:10.1155/2008/ 102737

170. Ashby J, Brady A, Elcombe CR, et al. Mechanistically-based human hazard assessment of peroxisome proliferator-induced hepatocarcinogenesis. Hum Exp Toxicol. 1994;13(Suppl 2):S1S117. doi:10.1177/096032719401300201

171. Issemann I, Green S. Activation of a member of the steroid hormone receptor superfamily by peroxisome proliferators. Nature. 1990;347:645-650. doi:10.1038/347645a0

172. Reddy JK, Azarnoff DL, Hignite CE. Hypolipidaemic hepatic peroxisome proliferators form a novel class of chemical carcinogens. Nature. 1980;283:397-398. doi:10.1038/283397a0

173. Saha SA, Kizhakepunnur LG, Bahekar A, Arora RR. The role of fibrates in the prevention of cardiovascular disease - a pooled meta-analysis of long-term randomized placebo-controlled clinical trials. Am Heart J. 2007;154(5):943-953. doi:10.1016/j. ahj.2007.07.011

174. Park BH, Vogelstein B, Kinzler KW. Genetic disruption of PPAR $\delta$ decreases the tumorigenicity of human colon cancer cells. Proc Natl Acad Sci U S A. 2001;98(5):2598-2603. doi:10.1073/pnas.051630998

175. Wang D, Wang H, Guo Y, et al. Crosstalk between peroxisome proliferator-activated receptor $\delta$ and VEGF stimulates cancer progression. Proc Natl Acad Sci U S A. 2006;103(50):1906919074. doi:10.1073/pnas.0607948103

176. Zuo X, Peng Z, Moussalli MJ, et al. Targeted genetic disruption of peroxisome proliferator-activated receptor- $\delta$ and colonic tumorigenesis. J Natl Cancer Inst. 2009;101(10):762-767. doi:10.1093/jnci/djp078

177. Harman FS, Nicol CJ, Marin HE, Ward JM, Gonzalez FJ, Peters JM. Peroxisome proliferator-activated receptor-delta attenuates colon carcinogenesis. Nat Med. 2004;10(5):481-483. doi: $10.1038 / \mathrm{nm} 1026$

178. Marin HE, Peraza MA, Billin AN, et al. Ligand activation of peroxisome proliferator-activated receptor beta inhibits colon carcinogenesis. Cancer Res. 2006;66(8):4394-4401. doi:10.1158/ 0008-5472.CAN-05-4277

179. Divya GS, Mansoor KP, Rasheed SP, Kumar A. PPAR gamma agonists: an effective strategy for cancer treatment. J Pharm Sci Innov. 2013;2(5):1-3. doi:10.7897/2277-4572.02575

180. Kitamura S, Miyazaki Y, Hiraoka S, et al. PPARgamma agonists inhibit cell growth and suppress the expression of cyclin D1 and EGF-like growth factors in ras-transformed rat intestinal epithelial cells. Int J Cancer. 2001;94(3):335-342. doi:10.1002/ijc.1470

181. Yang WL, Frucht H. Activation of the PPAR pathway induces apoptosis and COX-2 inhibition in HT-29 human colon cancer cells. Carcinogenesis. 2001;22(9):1379-1383. doi:10.1093/car$\operatorname{cin} / 22.9 .1379$

182. Lefebvre AM, Chen I, Desreumaux P, et al. Activation of the peroxisome proliferator-activated receptor $\gamma$ promotes the development of colon tumors in C57BL/6J-APCMin/+ mice. Nature Med. 1998;4(9):1053-1057.

183. Saez E, Tontonoz P, Nelson MC, et al. Activators of the nuclear receptor PPARgamma enhance colon polyp formation. Nat Med. 1998;4(9):1058-1061. doi:10.1038/2042

184. Xu F, Na L, Li Y, Chen L. Roles of the PI3K/AKT/mTOR signalling pathways in neurodegenerative diseases and tumours. Cell Biosci. 2020;10(1):54. doi:10.1186/s13578-020-00416-0

185. Hemmings BA, Restuccia DF. PI3K-PKB/Akt Pathway. Cold Spring Harb Perspect Biol. 2012;4(9):a011189. doi:10.1101/ cshperspect.a011189
186. Ortega MA, Fraile-Martínez O, Asúnsolo A, Buján J, GarcíaHonduvilla N, Coca S. Signal transduction pathways in breast cancer: the important role of PI3K/Akt/mTOR. $J$ Oncol. 2020;2020:9258396. doi:10.1155/2020/9258396

187. Paplomata E, O'Regan R. The PI3K/AKT/mTOR pathway in breast cancer: targets, trials and biomarkers. Ther Adv Med Oncol. 2014;6(4):154-166. doi:10.1177/1758834014530023

188. Liu R, Chen Y, Liu G, et al. PI3K/AKT pathway as a key link modulates the multidrug resistance of cancers. Cell Death Dis. 2020;11(9):797. doi:10.1038/s41419-020-02998-6

189. Brown KK, Toker A. The phosphoinositide 3-kinase pathway and therapy resistance in cancer. F1000Prime Rep. 2015;7:13. doi:10.12703/P7-13

190. Wilks ST. Potential of overcoming resistance to HER2-targeted therapies through the PI3K/Akt/mTOR pathway. Breast. 2015;24 (5):548-555. doi:10.1016/j.breast.2015.06.002

191. Li S, Patel DJ. Drosha and dicer: slicers cut from the same cloth. Cell Res. 2016;26(5):511-512. doi:10.1038/cr.2016.19

192. Dong Y, Fu C, Guan H, Zhang Z, Zhou T, Li B. Prognostic significance of miR-126 in various cancers: a meta-analysis. Onco Targets Ther. 2016;9:2547-2555. doi:10.2147/OTT. S103481

193. Meister J, Schmidt MHH. miR-126 and miR-126*: new Players in Cancer. ScientificWorldJournal. 2010;10:2090-2100. doi:10.1100/tsw.2010.198

194. Tavazoie SF, Alarcón C, Oskarsson T, et al. Endogenous human microRNAs that suppress breast cancer metastasis. Nature. 2008;451(7175):147-152. doi:10.1038/nature06487

195. Wang CZ, Yuan P, Li Y. MiR-126 regulated breast cancer cell invasion by targeting ADAM9. Int J Clin Exp Pathol. 2015;8 (6):6547-6553.

196. Chumsri S, Howes T, Bao T, Sabnis G, Brodie A. Aromatase, aromatase inhibitors, and breast cancer. $J$ Steroid Biochem Mol Biol. 2011;125(1-2):13-22. doi:10.1016/j.jsbmb.2011.02.001

197. Saha Roy S, Vadlamudi RK. Role of estrogen receptor signaling in breast cancer metastasis. Int $J$ Breast Cancer. 2012;2012:654698. doi:10.1155/2012/654698

198. Chumsri S. Clinical utilities of aromatase inhibitors in breast cancer. Int $J$ Womens Health. 2015;7:493-499. doi:10.2147/ IJWH.S69907

199. Zhao H, Innes J, Brooks DC, et al. A novel promoter controls Cyp19al gene expression in mouse adipose tissue. Reprod Biol Endocrinol. 2009;7(1):37. doi:10.1186/1477-7827-7-37

200. Zhao H, Zhou L, Shangguan AJ, Bulun SE. Aromatase expression and regulation in breast and endometrial cancer. $J \mathrm{Mol}$ Endocrinol. 2016;57(1):R19-R33. doi:10.1530/JME-15-0310

201. Chen S, Zhou D, Okubo T, et al. Prevention and treatment of breast cancer by suppressing aromatase activity and expression. Ann N Y Acad Sci. 2002;963(1):229-238. doi:10.1111/j.17496632.2002.tb04115.x

202. Sun F, Xu X, Wang X, Zhang B. Regulation of autophagy by $\mathrm{Ca}^{2}$ ${ }^{+}$. Tumour Biol. 2016;37(12):15467-15476. doi:10.1007/s13277016-5353-y

203. Machaca K. Ca2+ signaling, genes and the cell cycle. Cell Calcium. 2010;48(5):243-250. doi:10.1016/j.ceca.2010.10.003

204. Pinton P, Giorgi C, Siviero R, Zecchini E, Rizzuto R. Calcium and apoptosis: ER-mitochondria $\mathrm{Ca} 2+$ transfer in the control of apoptosis. Oncogene. 2008;27(50):6407-6418. doi:10.1038/ onc. 2008.308

205. Tonelli FMP, Santos AK, Gomes DA, et al. Stem cells and calcium signaling. Adv Exp Med Biol. 2012;740:891-916.

206. Baran I. Calcium and cell cycle progression: possible effects of external perturbations on cell proliferation. Biophys J. 1996;70 (3):1198-1213. doi:10.1016/S0006-3495(96)79679-0 
207. Iamshanova O, Fiorio Pla A, Prevarskaya N. Molecular mechanisms of tumour invasion: regulation by calcium signals. J Physiol. 2017;595(10):3063-3075. doi:10.1113/JP272844

208. Rimessi A, Pedriali G, Vezzani B, et al. Interorganellar calcium signaling in the regulation of cell metabolism: a cancer perspective. Semin Cell Dev Biol. 2020;98:167-180.

209. Tsai FC, Kuo GH, Chang SW, Tsai PJ. Ca2+ signaling in cytoskeletal reorganization, cell migration, and cancer metastasis. Biomed Res Int. 2015;2015:409245. doi:10.1155/2015/409245

210. Vilborg A, Passarelli MC, Steitz JA. Calcium signaling and transcription: elongation, DoGs, and eRNAs. Receptors Clin Investig. 2016;3(1):e1169.

211. Pratt SJP, Hernández-Ochoa E, Martin SS. Calcium signaling: breast cancer's approach to manipulation of cellular circuitry. Biophys Rev. 2020;12(6):1343-1359. doi:10.1007/s12551-02000771-9

212. Bootman MD. Calcium signaling. Cold Spring Harb Perspect Biol. 2012;4(7):a011171. doi:10.1101/cshperspect.a011171

213. Yáñez M, Gil-Longo J, Campos-Toimil M. Calcium binding proteins. Adv Exp Med Biol. 2012;740:461-482.

214. So CL, Saunus JM, Roberts-Thomson SJ, Monteith GR. Calcium signalling and breast cancer. Semin Cell Dev Biol. 2019;94:74-83. doi:10.1016/j.semcdb.2018.11.001

215. Ghosh S, May MJ, Kopp EB. NF-kappa B and Rel proteins: evolutionarily conserved mediators of immune responses. Annu Rev Immunol. 1998;16(1):225-260. doi:10.1146/annurev. immunol.16.1.225

216. Wang W, Nag SA, Zhang R. Targeting the NFкB signaling pathways for breast cancer prevention and therapy. Curr Med Chem. 2015;22(2):264-289. doi:10.2174/0929867321666141106124315

217. Ghosh G, Wang VY, Huang DB, Fusco A. NF- $\kappa$ B regulation: lessons from structures. Immunol Rev. 2012;246(1):36-58. doi:10.1111/j.1600-065X.2012.01097.x

218. O'Dea E, Hoffmann A. NF-кB signaling. Wiley Interdiscip Rev Syst Biol Med. 2009;1(1):107. doi:10.1002/wsbm.30

219. Liu T, Zhang L, Joo D, Sun SC. NF- $\kappa$ B signaling in inflammation Signal Transduct Target Ther. Signal Transduct Targeted Therapy. 2017;2:17023.

220. Park YH. The nuclear factor-kappa B pathway and response to treatment in breast cancer. Pharmacogenomics. 2017;18 (18):1697-1709. doi:10.2217/pgs-2017-0044

221. Huber MA, Azoitei N, Baumann B, et al. NF-kappaB is essential for epithelial-mesenchymal transition and metastasis in a model of breast cancer progression. J Clin Invest. 2004;114(4):569-581. doi:10.1172/JCI200421358

222. Khongthong P, Roseweir AK, Edwards J. The NF-KB pathway and endocrine therapy resistance in breast cancer. Endocr Relat Cancer. 2019;26(6):R369-R380. doi:10.1530/ERC-19-0087

223. Li F, Sethi G. Targeting transcription factor NF-kappaB to overcome chemoresistance and radioresistance in cancer therapy. Biochim Biophys Acta. 2010;1805(2):167-180.

224. Shibata A, Nagaya T, Imai T, Funahashi H, Nakao A, Seo H. Inhibition of NF- $\kappa \mathrm{B}$ activity decreases the VEGF mRNA expression in MDA-MB-231 breast cancer cells. Breast Cancer Res Treat. 2002;73(3):237-243. doi:10.1023/A:1015872531675

225. Xia Y, Shen S, Verma IM. NF- $\kappa$ B, an active player in human cancers. Cancer Immunol Res. 2014;2(9):823-830. doi:10.1158/ 2326-6066.CIR-14-0112

226. Baud V, Karin M. Is NF- $\kappa \mathrm{B}$ a good target for cancer therapy? Hopes and pitfalls. Nat Rev Drug Discov. 2009;8(1):33-40. doi:10.1038/nrd2781

227. Viatour P, Merville MP, Bours V, Chariot A. Phosphorylation of NF-kB and IkB proteins: implications in cancer and inflammation. Trends Biochem Sci. 2005;30(1):43-52. doi:10.1016/j. tibs.2004.11.009
228. Sarkar A, Sreenivasan Y, Ramesh GT, Manna SK. beta-DGlucoside suppresses tumor necrosis factor-induced activation of nuclear transcription factor kappaB but potentiates apoptosis. $J$ Biol Chem. 2004;279(32):33768-33781. doi:10.1074/jbc. M403424200

229. Komiya Y, Habas R. Wnt signal transduction pathways. Organogenesis. 2008;4(2):68-75. doi:10.4161/org.4.2.5851

230. He X, Semenov M, Tamai K, Zeng X. LDL receptor-related proteins 5 and 6 in $\mathrm{Wnt} / \beta$-catenin signaling: arrows point the way. Development. 2004;131(8):1663-1677. doi:10.1242/ dev.01117

231. MacDonald BT, Tamai K, He X. Wnt/ $\beta$-catenin signaling: components, mechanisms, and diseases. Dev Cell. 2009;17(1):9-26. doi:10.1016/j.devcel.2009.06.016

232. Khalaf AM, Fuentes D, Morshid AI, et al. Role of Wnt $/ \beta$-catenin signaling in hepatocellular carcinoma, pathogenesis, and clinical significance. $J$ Hepatocell Carcinoma. 2018;5:61-73. doi:10.2147/JHC.S156701

233. Sethi JK, Vidal-Puig A. Wnt signalling and the control of cellular metabolism. Biochem J. 2010;427(1):1-17. doi:10.1042/ BJ20091866

234. Ren L, Chen H, Song J, et al. MiR-454-3p-mediated Wnt/ $\beta$ catenin signaling antagonists suppression promotes breast cancer metastasis. Theranostics. 2019;9(2):449-465. doi:10.7150/ thno. 29055

235. Arend RC, Londoño-Joshi AI, Straughn JMJ, Buchsbaum DJ. The Wnt/ $\beta$-catenin pathway in ovarian cancer: a review. Gynecol Oncol. 2013;131(3):772-779. doi:10.1016/j. ygyno.2013.09.034

236. De P, Carlson JH, Wu H, Marcus A, Leyland-Jones B, Dey N. Wnt-beta-catenin pathway signals metastasis-associated tumor cell phenotypes in triple negative breast cancers. Oncotarget. 2016;7(28):43124-43149. doi:10.18632/oncotarget.8988

237. Qu B, Liu BR, Du YJ, et al. Wnt/ $\beta$-catenin signaling pathway may regulate the expression of angiogenic growth factors in hepatocellular carcinoma. Oncol Lett. 2014;7(4):1175-1178. doi: $10.3892 / \mathrm{ol} .2014 .1828$

238. Jang GB, Kim JY, Cho SD, et al. Blockade of Wnt/ $\beta$-catenin signaling suppresses breast cancer metastasis by inhibiting CSC-like phenotype. Sci Rep. 2015;5(1):12465. doi:10.1038/ srep 12465

239. DeBose-Boyd RA. Feedback regulation of cholesterol synthesis: sterol-accelerated ubiquitination and degradation of HMG CoA reductase. Cell Res. 2008;18(6):609-621. doi:10.1038/cr.2008.61

240. Danilo C, Frank PG. Cholesterol and breast cancer development. Curr Opin Pharmacol. 2012;12(6):677-682. doi:10.1016/j. coph.2012.07.009

241. Santos CR, Domingues G, Matias I, et al. LDL-cholesterol signaling induces breast cancer proliferation and invasion. Lipids Health Dis. 2014;13(1):16. doi:10.1186/1476-511X-13-16

242. Stancu C, Sima A. Statins: mechanism of action and effects. $J$ Cell Mol Med. 2001;5(4):378-387. doi:10.1111/j.15824934.2001.tb00172.x

243. Borgquist S, Bjarnadottir O, Kimbung S, Ahern TP. Statins: a role in breast cancer therapy? J Intern Med. 2018;284(4):346-357. doi:10.1111/joim.12806

244. Huang Q, Figueiredo-Pereira ME. Ubiquitin/proteasome pathway impairment in neurodegeneration: therapeutic implications. Apoptosis. 2010;15(11):1292-1311.

245. Crawford LJ, Walker B, Irvine AE. Proteasome inhibitors in cancer therapy. J Cell Commun Signal. 2011;5(2):101-110. doi:10.1007/s12079-011-0121-7

246. Agyin JK, Santhamma B, Nair HB, Roy SS, Tekmal RR. BU-32: a novel proteasome inhibitor for breast cancer. Breast Cancer Res. 2009;11(5):R74. doi:10.1186/bcr2411 
247. Jones MD, Liu JC, Barthel TK, et al. A proteasome inhibitor, bortezomib, inhibits breast cancer growth and reduces osteolysis by downregulating metastatic genes. Clin Cancer Res. 2010;16 (20):4978-4989. doi:10.1158/1078-0432.CCR-09-3293

248. Shinohara K, Tomioka M, Nakano H, Toné S, Ito H, Kawashima $\mathrm{S}$. Apoptosis induction resulting from proteasome inhibition. Biochem J. 1996;317(Pt 2):385-388. doi:10.1042/bj3170385

249. van der Vorm LN, Remijn JA, de Laat B, Huskens D. Effects of plasmin on von Willebrand factor and platelets: a narrative review. TH Open. 2018;2(2):e218-e228.

250. Didiasova M, Wujak L, Wygrecka M, Zakrzewicz D. From plasminogen to plasmin: role of plasminogen receptors in human cancer. Int J Mol Sci. 2014;15(11):21229-21252. doi:10.3390/ ijms151121229

251. Swedberg JE, Harris JM. Natural and engineered plasmin inhibitors: applications and design strategies. Chembiochem. 2012;13 (3):336-348. doi:10.1002/cbic.201100673

252. Castellino FJ, Ploplis VA. Structure and function of the plasminogen/plasmin system. Thromb Haemost. 2005;93(4):647-654. doi:10.1160/TH04-12-0842

253. Deryugina EI, Quigley JP. Cell surface remodeling by plasmin: a new function for an old enzyme. $J$ Biomed Biotechnol. 2012;2012:564259. doi:10.1155/2012/564259

254. Hayashido Y, Hamana T, Yoshioka Y, Kitano H, Koizumi K, Okamoto T. Plasminogen activator/plasmin system suppresses cell-cell adhesion of oral squamous cell carcinoma cells via proteolysis of E-cadherin. Int J Oncol. 2005;27(3):693-698.

255. Spiering D, Hodgson L. Dynamics of the Rho-family small GTPases in actin regulation and motility. Cell Adh Migr. 2011;5 (2):170-180. doi:10.4161/cam.5.2.14403

256. Algayadh IG, Dronamraju V, Sylvester PW. Role of Rac1/ WAVE2 signaling in mediating the inhibitory effects of $\gamma$-tocotrienol on mammary cancer cell migration and invasion. Biol Pharm Bull. 2016;39(12):1974-1982. doi:10.1248/bpb.b16-00461

257. Bompard G, Caron E. Regulation of WASP/WAVE proteins: making a long story short. J Cell Biol. 2004;166(7):957-962. doi:10.1083/jcb.200403127

258. Kurisu S, Takenawa T. WASP and WAVE family proteins: friends or foes in cancer invasion? Cancer Sci. 2010;101(10):2093-2104. doi:10.1111/j.1349-7006.2010.01654.x

259. Fernando HS, Davies SR, Chhabra A, et al. Expression of the WASP verprolin-homologues (WAVE members) in human breast cancer. Oncology. 2007;73(5-6):376-383. doi:10.1159/ 000136157

260. Porter BA, Ortiz MA, Bratslavsky G, Kotula L. Structure and function of the nuclear receptor superfamily and current targeted therapies of prostate cancer. Cancers. 2019;11(12):1852. doi:10.3390/cancers11121852

261. Björnström L, Sjöberg M. Mechanisms of estrogen receptor signaling: convergence of genomic and nongenomic actions on target genes. Mol Endocrinol. 2005;19(4):833-842. doi:10.1210/ me.2004-0486

262. Acconcia F, Kumar R. Signaling regulation of genomic and nongenomic functions of estrogen receptors. Cancer Lett. 2006;238 (1):1-14. doi:10.1016/j.canlet.2005.06.018

263. Vrtačnik P, Ostanek B, Mencej-Bedrač S, Marc J. The many faces of estrogen signaling. Biochem Med (Zagreb). 2014;24(3):329342. doi:10.11613/BM.2014.035

264. Williams C, Lin CY. Oestrogen receptors in breast cancer: basic mechanisms and clinical implications. Ecancermedicalscience. 2013;7(1):370.

265. Hartman J, Gustafsson JA. Estrogen receptor beta in breast cancer-diagnostic and therapeutic implications. Steroids. 2009;74 (8):635-641. doi:10.1016/j.steroids.2009.02.005
266. Powell E, Shanle E, Brinkman A, et al. Identification of estrogen receptor dimer selective ligands reveals growth-inhibitory effects on cells that co-express ER $\alpha$ and ER $\beta$. PLoS One. 2012;7(2): e30993. doi:10.1371/journal.pone.0030993

267. Sanz P. AMP-activated protein kinase: structure and regulation. Curr Protein Pept Sci. 2008;9(5):478-492. doi:10.2174/ 138920308785915254

268. Mihaylova MM, Shaw RJ. The AMP-activated protein kinase (AMPK) signaling pathway coordinates cell growth, autophagy, \& metabolism. Nat Cell Biol. 2011;13(9):1016-1023. doi:10.1038/ncb2329

269. Xu Q, Si LY. Protective effects of AMP-activated protein kinase in the cardiovascular system. J Cell Mol Med. 2010;14(11):26042613. doi:10.1111/j.1582-4934.2010.01179.x

270. Hinchy EC, Gruszczyk AV, Willows R, et al. Mitochondriaderived ROS activate AMP-activated protein kinase (AMPK) indirectly. $J$ Biol Chem. 2018;293(44):17208-17217. doi:10.1074/jbc.RA118.002579

271. Rabinovitch RC, Samborska B, Faubert B, et al. AMPK maintains cellular metabolic homeostasis through regulation of mitochondrial reactive oxygen species. Cell Rep. 2017;21(1):1-9. doi:10.1016/j.celrep.2017.09.026

272. Wang S, Song P, Zou MH. AMP-activated protein kinase, stress responses and cardiovascular diseases. Clin Sci (Lond). 2012;122 (12):555-573. doi:10.1042/CS20110625

273. Yi Y, Chen D, Ao J, et al. Transcriptional suppression of AMPK $\alpha 1$ promotes breast cancer metastasis upon oncogene activation. Proc Natl Acad Sci U S A. 2020;117(14):8013-8021. doi:10.1073/pnas.1914786117

274. Fox MM, Phoenix KN, Kopsiaftis SG, Claffey KP. AMP-activated protein kinase $\alpha 2$ isoform suppression in primary breast cancer alters AMPK growth control and apoptotic signaling. Genes Cancer. 2013;4(1-2):3-14. doi:10.1177/ 1947601913486346

275. Jhaveri TZ, Woo J, Shang X, Park BH, Gabrielson E. AMPactivated kinase (AMPK) regulates activity of HER2 and EGFR in breast cancer. Oncotarget. 2015;6(17):14754-14765. doi:10.18632/oncotarget.4474

276. Zou YF, Xie CW, Yang SX, Xiong JP. AMPK activators suppress breast cancer cell growth by inhibiting DVL3-facilitated Wnt/ $\beta$ catenin signaling pathway activity. Mol Med Rep. 2017;15 (2):899-907. doi:10.3892/mmr.2016.6094

277. Ben-Sahra I, Dirat B, Laurent K, et al. Sestrin2 integrates Akt and mTOR signaling to protect cells against energetic stress-induced death. Cell Death Differ. 2013;20(4):611-619. doi:10.1038/ cdd.2012.157

278. Kim SH, Park S, Yu HS, Ko KH, Park HG, Kim YS. The antipsychotic agent clozapine induces autophagy via the AMPKULK1-Beclin1 signaling pathway in the rat frontal cortex. Prog Neuropsychopharmacol Biol Psychiatry. 2018;81:96-104. doi:10.1016/j.pnpbp.2017.10.012

279. Vermeulen K, Van Bockstaele DR, Berneman ZN. The cell cycle: a review of regulation, deregulation and therapeutic targets in cancer. Cell Prolif. 2003;36(3):131-149. doi:10.1046/j.13652184.2003.00266.x

280. Casimiro MC, Crosariol M, Loro E, Li Z, Pestell RG. Cyclins and cell cycle control in cancer and disease. Genes Cancer. 2012;3 (11-12):649-657. doi:10.1177/1947601913479022

281. Topacio BR, Zatulovskiy E, Cristea S, et al. Cyclin D-Cdk4,6 drives cell-cycle progression via the retinoblastoma protein's c-terminal helix. Mol Cell. 2019;74(4):758-770. doi:10.1016/j. molcel.2019.03.020 
282. Bertoli C, Skotheim JM, de Bruin RA. Control of cell cycle transcription during G1 and S phases. Nat Rev Mol Cell Biol. 2013;14(8):518-528. doi:10.1038/nrm3629

283. Voeller D, Rahman L, Zajac-Kaye M. Elevated levels of thymidylate synthase linked to neoplastic transformation of mammalian cells. Cell Cycle. 2004;3(8):1005-1007. doi:10.4161/cc.3.8.1064

284. Narasimha AM, Kaulich M, Shapiro GS, Choi YJ, Sicinski P, Dowdy SF. Cyclin D activates the Rb tumor suppressor by monophosphorylation. eLife. 2014;3:e02872. doi:10.7554/eLife.02872

285. Lara-Gonzalez P, Moyle MW, Budrewicz J, Mendoza-Lopez J, Oegema K, Desai A. The G2-to-M transition is ensured by a dual mechanism that protects cyclin $\mathrm{B}$ from degradation by $\mathrm{Cdc} 20$ activated APC/C. Dev Cell. 2019;51(3):313-325. doi:10.1016/j. devcel.2019.09.005
286. Tavakolian S, Goudarzi H, Faghihloo E. Cyclin-dependent kinases and $\mathrm{CDK}$ inhibitors in virus-associated cancers. Infect Agent Cancer. 2020;15:27. doi:10.1186/s13027-020-00295-7

287. Thu KL, Soria-Bretones I, Mak TW, Cescon DW. Targeting the cell cycle in breast cancer: towards the next phase. Cell Cycle. 2018;17(15):1871-1885. doi:10.1080/15384101.2018.1502567

288. The Cancer Genome Atlas Network. Comprehensive molecular portraits of human breast tumors. Nature. 2012;490(7418):61-70. doi:10.1038/nature11412

\section{Publish your work in this journal}

Breast Cancer - Targets and Therapy is an international, peer-reviewed open access journal focusing on breast cancer research, identification of therapeutic targets and the optimal use of preventative and integrated treatment interventions to achieve improved outcomes, enhanced survival and quality of life for the cancer patient.
The manuscript management system is completely online and includes a very quick and fair peer-review system, which is all easy to use. Visit http://www.dovepress.com/testimonials.php to read real quotes from published authors. 